\title{
Meteorological Field Measurements at Potential and Actual Wind Turbine Sites
}
D. S. Renné
W. F. Sandusky
D. L. Hadley

September 1982

Prepared for the U.S. Department of Energy under Contract DE-AC06-76RLO 1830

Pacific Northwest Laboratory Operated for the U.S. Department of Energy by Battelle Memorial Institute 


\title{
DISCLAIMER
}

This report was prepared as an account of work sponsored by an agency of the United States Government. Neither the United States Government nor any agency thereof, nor any of their employees, makes any warranty, express or implied, or assumes any legal liability or responsibility for the accuracy, completeness, or usefulness of any information, apparatus, product, or process disclosed, or represents that its use would not infringe privately owned rights. Reference herein to any specific commercial product, process, or service by trade name, trademark, manufacturer, or otherwise, does not necessarily constitute or imply its endorsement, recommendation, or favoring by the United States Government or any agency thereof. The views and opinions of authors expressed herein do not necessarily state or reflect those of the United States Government or any agency thereof.

\author{
PACIFIC NORTHWEST I.ABORATORY \\ operated by \\ BATTELLE \\ for the \\ UNITED STATES DEPARTMENT OF ENERGY \\ under Contract DE-AC06-76RLO 1830
}

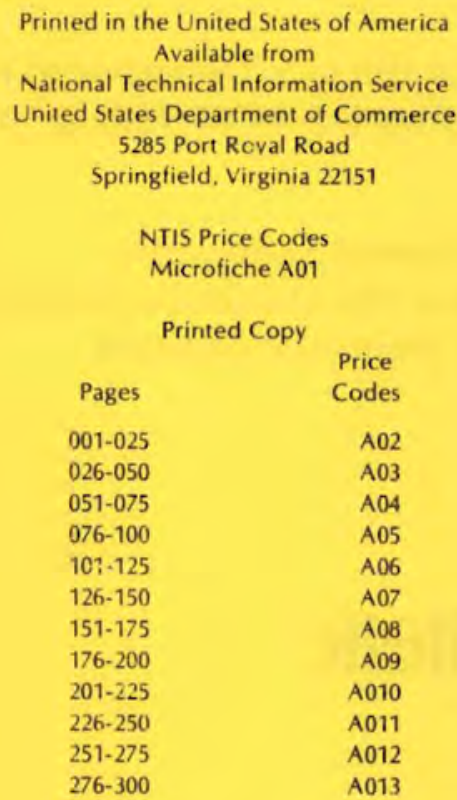




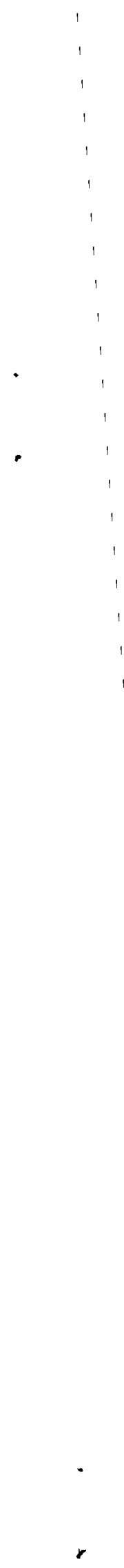


METEOROLOGICAL FIELD MEASUREMENTS AT

POTENTIAL AND ACTUAL WIND TURBINE SITES
D. S. Renné
W. F. Sandusky
D. L. Hadley

September 1982

Prepared for the U.S. Department of Energy under Contract DE-ACO6-76RLO 1830

Pacific Northwest Laboratory Richland, Washington 99352 


\section{SUMMARY}

Since 1976 the U.S. Department of Energy (DOE) has sponsored field. measurement programs at a number of sites around the United States that appear promising for wind energy utilization. From time to time a site from this group has been chosen for installation of a large wind turbine for field testing. After the installation, the wind measurement activities are expanded to simultaneously record wind data from the meteorological tower and turbine performance data.

This measurement program has produced information, not only on wind characteristics in a variety of windy locations, but also on procedures for obtaining reliable and accurate wind measurements in harsh environments. In addition, with the availability of turbine data at some of these sites, this program has provided insight into the most appropriate measurement strategies at a potential wind turbine site so that estimates of machine performance and potential hazards to the machine can be obtained efficiently. This report summarizes these field measurement experiences.

Experience in this program has shown that unless the data logging equipment is given proper protection, a high percentage of data can be lost in severe weather conditions or high moisture environments due to failure of microprocessing components. In addition, although the more sensitive sensors can provide turbulence-scale information that may prove valuable for identifying hazards to machines, a certain amount of data recovery is sacrificed under icing or high wind conditions which can damage the more fragile types of sensors. Rigid calibration and maintenance procedures must be established to assure a successful program.

Statistical analyses of high-frequency data collected at sites with wind turbines have indicated that time-averaged sampling is preferable over instantaneous sampling. Although the instantaneous samples are adequate for climatological representativeness, time-averaged samples are more realistic for simulating turbine operations and for correlating wind speed measurements at the tower with turbine power output. A sampling scheme that records data averaged over several different time scales is prescribed. 


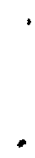

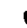




\section{CONTENTS}

SUMMARY. . . . . . . . . . . . . . . . . . . . . . .

1. INTRODUCTION . . . . . . . . . . . . . . . . . . . 1

2. PROGRAM HISTORY. . . . . . . . . . . . . . . . . . . 3

3. DATA COLLECTION HISTORY. . . . . . . . . . . . . . . . . . 7

3.1 THE FIRST TWO YEARS . . . . . . . . . . . . . . . . . 7

3.2 THE MEASUREMENT PROGRAM SINCE 1978. . . . . . . . . . . . 9

4. DATA COLLECTION PROCEDURES . . . . . . . . . . . . . . . . 13

4.1 CALIBRATION AND MAINTENANCE . . . . . . . . . . . . . . . 13

4.2 Site MAINTENANCE, DATA Editing, AND REDUCTION . . . . . . . 13

4.3 DATA REPORTING. . . . . . . . . . . . . . . . . . 15

4.4 QUALITY ASSURANCE . . . . . . . . . . . . . . . . 16

4.5 CURRENT PROGRAM AND DATA BASE DEVELOPMENT . . . . . . . . . . 16

5. TURBINE INSTALLATION SITES . . . . . . . . . . . . . . . . 19

6. SUMMARY OF FIELD EXPERIENCE. . . . . . . . . . . . . . . 21

7. RECOMMENDATIONS FOR FUTURE SITE EVALUATION PROGRAMS. . . . . . . . 25

7.1 TOWER AND EQUIPMENT CONFIGURATIONS. . . . . . . . . . . . 25

7.2 SAMPLING AND DATA PROCESSING PROCEDURES . . . . . . . . . 26

REFERENCES .......................... . . . . . . . . . . . . . . . . .

APPENDIX: INFORMATION ON THE LOCATION AND EXPOSURE OF THE

METEOROLOGICAL EQUIPMENT AT EACH OF THE CANDIDATE SITES • • A-1 


\section{FIGURES}

1 The Candidate Site Program During the Period 1976-1978. . .

\section{TABLES}

$1 \quad$ Pertinent Information About the 17 Candidate Sites

for Period December 1976 - September 1978 . . . . . . .

2 Pertinent Information About the 18 New Candidate Sites. .

$3 \quad$ Large Turbine Installation Sites for Field Testing

Selected During the Period 1976-1979. . . . . . . . .

$4 \quad$ Average Annual Wind Speed, $\mathrm{m} / \mathrm{s}$ at the $45.7 \mathrm{~m}$ Level at 36 Candidate Sites...............

A.1 Pertinent Information on the Location and Exposure of the Original 18 Candidate Sites............

A.2 Pertinent Information on the Location and Exposure of the 18 New Candidate Sites............. 


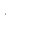




\section{INTRODUCTION}

This report provides an overview of experiences gained in a meteorological measurement program conducted at a number of locations around the United States for the purpose of site evaluation for wind energy utilization. The major emphasis of this report is to discuss the evolution of the measurement program from its inception in 1976 to the present day, ${ }^{(a)}$ to outline some of the major accomplishments and areas for improvement, and to present some conclusions on research utilizing data from this program that may be useful in future site evaluation exercises. We hope that, by sharing our experiences in undertaking field measurements in geographically dispersed and environmentally severe sites, others may benefit from the knowledge gained from this program.

(a) Summer of 1982 


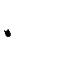




\section{PROGRAM HISTORY}

In 1976, the U.S. Department of Energy (then, the Energy Research and Development Administration) selected 17 candidate sites from among 64 proposals submitted by utility organizations. The candidate sites were those that showed promising wind energy potential and other site characteristics that qualified them for possible installation of large wind machines for field testing and utility operations. Following this selection, each site was eligible to receive a $48.8-\mathrm{m}(160-\mathrm{ft})$ tall meteorological tower with two levels $(9.1 \mathrm{~m}$ and $45.7 \mathrm{~m}$ ) of wind speed and direction sensors. Data from these sensors were to be recorded on strip-chart recorders.

The data collection programs were started in December 1976 at most of the sites shown in Figure 1. At this time the measurement program was conducted by the National Aeronautics and Space Administration (NASA)/Lewis Research Center, which is the Department of Energy's (DOE) lead laboratory for developing large, horizontal-axis wind turbines for field testing. From time to time, one of the 17 candidate sites was to be selected for receiving a wind turbine. (Figure 1 shows that 5 of these original 17 sites were selected for field testing wind turbines. Four received the 200-kW MOD-OA machine, and one received the 2000-kW MOD-1 machine.) The selection of these turbine sites was done competitively by applying a number of criteria, including wind energy availability, site characteristics, and utility support. These selections occurred over a three-year period through 1979. Details of this program have been described by Renné and Sandusky (1979).

In late 1978, Pacific Northwest Laboratory (PNL), which is DOE's major laboratory for providing technical and management support in the area of wind characteristics for the Federal Wind Energy Program, assumed the responsibility of this measurement program. Like NASA, PNL also hired a subcontractor to perform all site maintenance and calibration responsibilities, and data processing functions. In addition, the subcontractor replaced all stripchart recorders with digital cassette data loggers. This change-over was completed by the beginning of 1979 . 


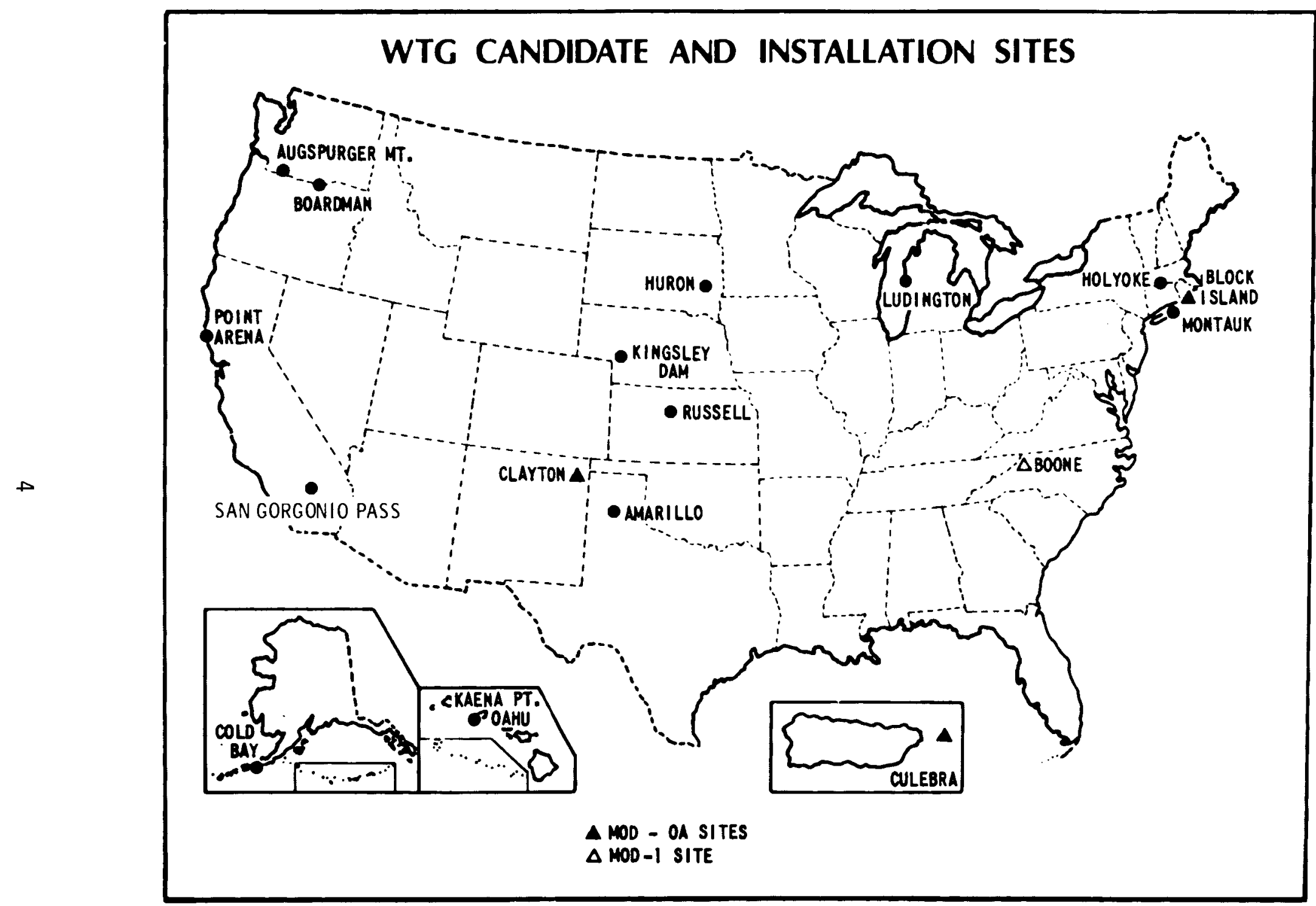

FIGURE 1. The Candidate Site Program During the Period 1976-1978 
In 1980 an additional 20 sites were added to the program. This was done in anticipation of a need for a larger variety of sites for field testing the next generation of large, horizontal-axis wind turbines. Ultimately, towers were installed at 18 of these 20 sites. Configuration of the measurement system at these new sites differed somewhat from those at the original 17 sites, as described in the next section. In 1981, after installation of large wind turbines at six sites (including the MOD-2 cluster at Goodnoe Hills, Washington), the emphasis of the DOE program was shifted from system development to technology research. Because of this, the candidate site program, which had also served to develop and apply techniques for analyzing wind resources and for prospecting for good sites, was curtailed. Measurements at most of the original 17 sites (with the exception of those having large wind turbines for field testing) were terminated. In 1982 the measurements at many of the newer sites continue under private support, with PNL continuing to provide assistance in data processing. Figure 2 shows the location of all candidate sites and their status as of early 1982. 
- active turbine sites

- active candidate sites

O DECOMMISSIONED CANDIDATE SITES

$\triangle$ DECOMMISSIONEO TURBINE SITE

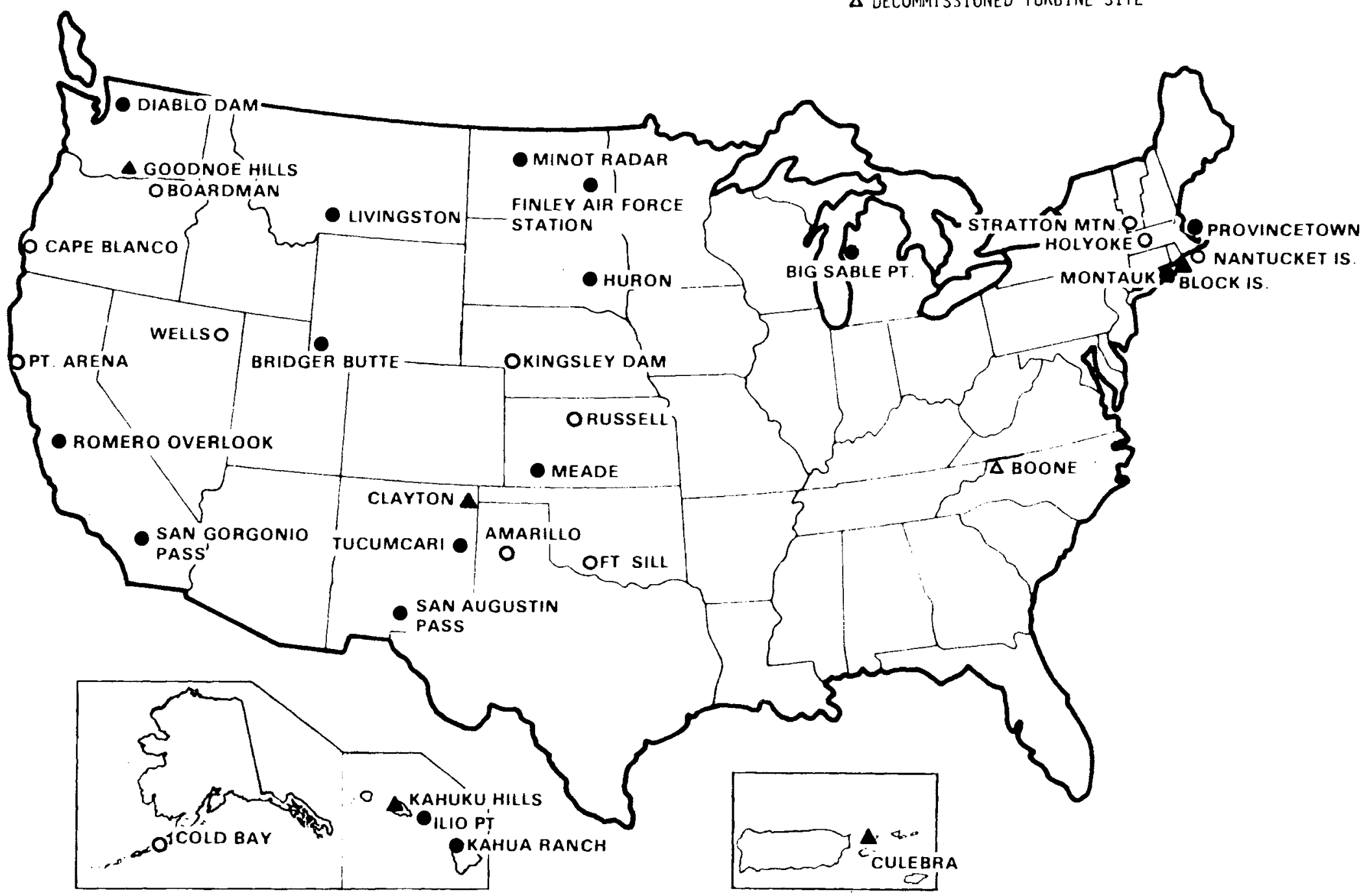

FIGURE 2. Status of the Candidate Site Program as of Mid-1982 


\section{DATA COLLECTION HISTORY}

\subsection{THE FIRST TWO YEARS}

From its beginning in 1976 through September 1978, the Meteorological Validation Program (MVP), as the candidate site meteorological measurement program has been called, was managed for DOE by the NASA/Lewis Research Center, Cleveland, Ohio. NASA selected Western Scientific Services, Inc. (WSSI), of Fort Collins, Colorado, as its meteorological measurement contractor to install data acquisition equipment at 15 of the original 17 sites (Table 1). The other two sites, Kaena Point and Boardman, had data acquisition programs in progress, and thus installation of government equipment was not required. At each site where government equipment was installed, the system basically consisted of a $48.8-\mathrm{m}(160-\mathrm{ft})$ Rohn (a) $55 \mathrm{G}$ tower with MRI (b) 1074 wind sensors at two levels. At the Ludington, Michigan, and Cold Bay, Alaska, sites the sensors were installed on existing towers. Data for each meteorological parameter were recorded as an analog signal on separate stripchart recorders. At most sites, the sensors were installed at the $9.1-m$ $(30-f t)$ and $45.7-m(150-f t)$ levels. At some sites the lower level was chosen to be $18.2 \mathrm{~m}(60 \mathrm{ft})$ to avoid effects on the measurements as a result of nearby obstructions. At Cold Bay, Alaska, the top-level sensor was mounted at the $21.8 \mathrm{~m}$ level on an FAA tower. At all sites, the tower was installed about 100 meters from where a wind turbine would actually be located.

The towers were generally placed upwind in the prevailing wind direction of the proposed turbine location. The purpose of this arrangement was to ensure that the tower would measure the free-stream wind characteristics so that the data could be used for performance evaluation of the turbine if the site were selected to receive one. Table 1 provides information on the measurements at these sites during this phase of the program. As noted in the table, some utilities supplied their own meteorological systems, while others made their own towers available to the program.

(a) Unarco-Rohn, Inc., P.0. Box 2000, Peoria, IL 61601

(b) Meteorology Research, Inc., 464 Woodbury Road, A1tadena, CA 91001 


\section{TABLE 1. Pertinent Information About the 17 Candidate Sites}

for Period December 1976 - September 1978

\begin{tabular}{|c|c|c|c|c|}
\hline Name of Site & Utility & $\begin{array}{l}\text { Instrument } \\
\text { Levels, m }\end{array}$ & $\begin{array}{c}\text { Start of } \\
\text { Measurements }\end{array}$ & $\begin{array}{c}\text { Status of } \\
\text { Measurements, } \\
1982 \\
\end{array}$ \\
\hline Amaril10, TX & Southwestern Public Service & $9.1,45.7$ & March 1977 & $\begin{array}{l}\text { Equip. trans- } \\
\text { ferred to the } \\
\text { U.S. Dept. of } \\
\text { Agricul ture }\end{array}$ \\
\hline Augspurger Mt., WA & Bonneville Power Admin. & $9.1,45.7$ & December 1976 & $\begin{array}{l}\text { Terminated } \\
\text { January } 1978\end{array}$ \\
\hline Block Island, RI & Block Island Power Company & $9.1,45.7$ & December 1976 & $\begin{array}{l}\text { Continuing by } \\
\text { DOE }\end{array}$ \\
\hline Boone, NC & $\begin{array}{l}\text { Blue Ridge Electric } \\
\text { Membership Cooperative }\end{array}$ & $18.2,45.7,83.8$ & December 1976 & $\begin{array}{l}\text { Terminated } \\
\text { July } 1981\end{array}$ \\
\hline Clayton, NM & City of Clayton & $9.1,30.0,45.7$ & May 1977 & $\begin{array}{l}\text { Continuing by } \\
\text { DOE }\end{array}$ \\
\hline Cold Bay, AK & Alaska Bussell Elec. Co. & $9.1,21.8^{(a)}$ & August 1977 & $\begin{array}{l}\text { Terminated } \\
\text { Sept. } 1981\end{array}$ \\
\hline Culebra, PR & Puerto Rico Power Auth. & $9.1,45.7$ & March 1977 & $\begin{array}{l}\text { Continuing by } \\
\text { DOE }\end{array}$ \\
\hline Holyoke, MA & Holyoke Gas \& Electric & $18.2,45.7$ & December 1976 & $\begin{array}{l}\text { Terminated } \\
\text { Sept. } 1981\end{array}$ \\
\hline Huron, SD & $\begin{array}{l}\text { East River Electric Power } \\
\text { Cooperative }\end{array}$ & $9.1,45.7$ & December 1976 & $\begin{array}{l}\text { Continuing } \\
\text { by utility }\end{array}$ \\
\hline Kingsley Dam, NE & $\begin{array}{l}\text { Central Nebraska Pub. } \\
\text { Power \& Irri. District }\end{array}$ & $9.1,45.7$ & December 1976 & $\begin{array}{l}\text { Terminated } \\
\text { August } 1981\end{array}$ \\
\hline Ludington, MI & Consumers Power Company & $18.2,45.7^{(a)}$ & Apri1 1977 & $\begin{array}{l}\text { Terminated } \\
\text { Oc tober } 1979\end{array}$ \\
\hline Montauk, Long Is., NY & Long Island Lighting $\mathrm{Co}$. & $18.2,45.7$ & January 1977 & $\begin{array}{l}\text { Continuing } \\
\text { by utility }\end{array}$ \\
\hline Point Arena, CA & Pacific Gas \& Elec. Co. & $9.1,45.7$ & January 1977 & $\begin{array}{l}\text { Terminated } \\
\text { Sept. } 1981\end{array}$ \\
\hline Russel1, KS & City of Russell & $9.1,45.7$ & December 1976 & $\begin{array}{l}\text { Terminated } \\
\text { August } 1981\end{array}$ \\
\hline San Gorgonio Pass, CA & Southern California Edison & $9.1,45.7$ & December 1976 & $\begin{array}{l}\text { Continuing by } \\
\text { DOE }\end{array}$ \\
\hline Boardman, OR & Portland General Electric & $9.1,39.6,70.1$ & January $1977^{(c)}$ & $\begin{array}{l}\text { Continuing } \\
\text { by utility }\end{array}$ \\
\hline Kaena Pt., $\mathrm{HI}$ & Hawaijan Electric Company & $9.1,45.7^{(b)}$ & December 1976 & $\begin{array}{l}\text { Terminated } \\
\text { October } 1979\end{array}$ \\
\hline
\end{tabular}

(a) Tower supplied by utility.

(b) Meteorological equipment, data reports supplied by utility.

(c) Data collected by the utility since 1974 .

(d) Data not supplied to DOE after September 1981. 
Under cooperative agreements established between NASA and the participating utilities, utility personnel were required to inspect the site on a weekly basis, change the strip charts every other visit and return them to WSSI for reduction. Upon receiving the strip charts from the utilities each month, WSSI arranged to have the data reduced by hand and summarized into hourly average wind speed and direction, hourly turbulent intensity and wind direction standard deviation. WSSI also prepared monthly data reports.

Because these 17 sites were involved in a competitive arrangement for receiving the first generation of wind turbines (totaling to four 200-kW MOD-OAs and one 2000-kW MOD-1), the distribution of the data reports was limited to DOE, NASA/Lewis, PNL, and the utilities.

\subsection{THE MEASUREMENT PROGRAM SINCE 1978}

In 1978, PNL, located in Richland, Washington, and operated for the Department of Energy by the Battelle Memorial Institute (BMI), assumed the responsibility of the MVP from NASA/Lewis. PNL selected Environmental Systems Corporation (ESC) of Knoxville, Tennessee, to provide calibration, maintenance, and data reduction services at the 14 candidate sites which had DOE equipment. (Measurements were terminated at Bonneville Power Administration's (BPA) Augspurger Mountain site in January 1978 when a severe ice storm caused the collapse of the meteorological tower.) The Kaena Point and Boardman sites continued to be operated by their respective utilities.

In the fall of 1978, ESC installed Tower Systems (a) instrument elevators and ESC CDL-700A digital cassette data loggers on each of the 14 towers. In a few cases the strip-chart recorders were retained as back-up systems. The data loggers were configured to record an instantaneous sample of each parameter once every two minutes. This allowed up to 17 days of data recording for each tape.

The data loggers were designed to operate unattended for two-week intervals using two 6-volt rechargeable batteries as a power source. At some sites

(a) Tower Systems, Inc., S. Hwy. 65, P.0. Box 308, Cambridge, MN 55008 
where ac power was available, the dc battery supply was still used to supply power to the logger, but a trickle charger was attached to the battery to maintain a full charge at all times. This allowed the data logger to continue functioning even if there were a power failure at the site.

A goal of $90 \%$ data recovery at each site was established for this program. Achieving this goal was challenging since, unlike other programs with similar goals, there were generally no back-up recording systems at the sites, and of ten the sensors and loggers could only be checked once weekly by utility personne1. In general, data recovery decreased during the winter months when severe weather hampered performance of the sensors and loggers.

In late 1979 and early 1980, the number of candidate sites was greatly expanded following the selection of 20 utility organizations who were to receive meteorological measurement equipment. In 1980, PNL's new subcontractor, Engineering-Science (E-S) of Arcadia, California, arranged for installation of meteorological measuring equipment at 18 of these new sites, and at the same time continued to maintain the original sites in the program. At the new sites, three levels of $\mathrm{Cl}$ imet $^{(a)}$ wind speed and direction sensors were installed at the 9.1-, 30.0-, and 45.7-m levels. A new model of the ESC data logger was used, although the sampling procedure remained identical to that at the original sites. A Tri-EX ${ }^{(b)}$ instrument elevator system was installed on the 48.8-m (160-ft) Rohn 55G tower at these new sites.

In 1981, as the Federal Wind Energy Program was transformed from a systems development program to a technology research program, measurements were concluded at most of the original candidate sites where five years of data had been collected. In 1982, after one year of data collection had been completed at the sites selected in 1980, the utilities were offered the DOE equipment that had been installed on their sites by the DOE in exchange for their commitment to maintain the equipment and provide data to DOE through PNL. Many of the sites opted for this transfer, although measurement

(a) CTimet Instrument Co., P.0. Box 151, Redlands, CA 92373

(b) Tri-EX, Inc., 7182 Rasmussen Ave., Rd. 76, Visalia, CA 93277 
programs were terminated at a few sites in January of 1982. Table 2 provides pertinent information about the sites that were selected in 1980, and includes the Kahuku, Hawaii, MOD-OA site. 
TABLE 2. Pertinent Information About the 18 New Candidate Sites (A11 Instrument Levels at $9.1 \mathrm{~m}, 30.5 \mathrm{~m}$, and $45.7 \mathrm{~m}$ Unless Otherwise Noted)

\begin{tabular}{|c|c|c|c|}
\hline Name of Site & Utility & $\begin{array}{c}\text { Start of } \\
\text { Measurements }\end{array}$ & $\begin{array}{c}\text { Status of } \\
\text { Measurements, } \\
1982 \\
\end{array}$ \\
\hline Big Sable Point, MI & Consumers Power & January 1981 & $\begin{array}{l}\text { Continuing by } \\
\text { utility }\end{array}$ \\
\hline Bridger Butte, WY & $\begin{array}{l}\text { Intermountain } \\
\text { Consumers Power }\end{array}$ & September 1980 & $\begin{array}{l}\text { Continuing by } \\
\text { utility }\end{array}$ \\
\hline Cape Blanco, OR & Coos-Curry Electric & November 1980 & $\begin{array}{l}\text { Terminated } \\
\text { October } 1981\end{array}$ \\
\hline Diablo Dam, WA & Seattle City Light & December 1980 & $\begin{array}{l}\text { Continuing by } \\
\text { utility }\end{array}$ \\
\hline Finley, ND & $\begin{array}{l}\text { Sheyenne Valley } \\
\text { Electric Coop. }\end{array}$ & October 1980 & $\begin{array}{l}\text { Continuing by } \\
\text { utility }\end{array}$ \\
\hline Fort Sill, OK & Department of Defense & September 1980 & $\begin{array}{l}\text { Terminated } \\
\text { January } 1982\end{array}$ \\
\hline Il io Point, Molokai, HI & Molokai Electric & January 1981 & $\begin{array}{l}\text { Continuing by } \\
\text { utility }\end{array}$ \\
\hline Kahua Ranch, Hawai i, HI & $\begin{array}{l}\text { Hawaiian Electric } \\
\text { Light Company }\end{array}$ & February 1981 & $\begin{array}{l}\text { Continuing by } \\
\text { utility }\end{array}$ \\
\hline Kahuku, HI & $\begin{array}{l}\text { Hawaiian Electric } \\
\text { Company }\end{array}$ & September 1980 & $\begin{array}{l}\text { Continuing by } \\
\text { utility }\end{array}$ \\
\hline Livingston, MT & Montana Power & September 1980 & $\begin{array}{l}\text { Continuing by } \\
\text { utility }\end{array}$ \\
\hline Meade, KS & City of Meade & July 1980 & $\begin{array}{l}\text { Continuing by } \\
\text { utility }\end{array}$ \\
\hline Minot, ND & $\begin{array}{l}\text { Verendrye Electric } \\
\text { Coop. }\end{array}$ & October 1980 & $\begin{array}{l}\text { Continuing by } \\
\text { utility }\end{array}$ \\
\hline Nantucket, MA & Nantucket Electric & November 1980 & $\begin{array}{l}\text { Terminated } \\
\text { January } 1982\end{array}$ \\
\hline Provincetown, $M A^{(a)}$ & $\begin{array}{l}\text { New Bedford Gas \& } \\
\text { Electric }\end{array}$ & January 1981 & $\begin{array}{l}\text { Continuing by } \\
\text { utility }\end{array}$ \\
\hline Romero Overlook, CA & $\begin{array}{l}\text { Department of Water } \\
\text { Resources }\end{array}$ & October 1980 & $\begin{array}{l}\text { Continuing by } \\
\text { utility }\end{array}$ \\
\hline San Augustin Pass, NM & El Paso Electric & November 1980 & $\begin{array}{l}\text { Continuing by } \\
\text { utility }\end{array}$ \\
\hline Stratton Mountain, VT & Vermont Electric & January 1981 & $\begin{array}{l}\text { Terminated } \\
\text { January } 1982\end{array}$ \\
\hline Tucumcari, NM & City of Tucumcari & November 1980 & $\begin{array}{l}\text { Continuing by } \\
\text { utility }\end{array}$ \\
\hline Wells, NV & Wells Rural Electric & October 1980 & $\begin{array}{l}\text { Terminated } \\
\text { January } 1982\end{array}$ \\
\hline
\end{tabular}

(a) Top levei sensor is at $42.7 \mathrm{~m}$.

NOTE: Two-minute instantaneous values of wind speed and direction recorded at all levels. 


\section{DATA COLLECTION PROCEDURES}

During the past four years when PNL conducted the measurement program at the candidate sites, the following procedures were established for performing maintenance, calibration, and data reduction by PNL's subcontractor. These procedures were followed until June 1981 when PNL assumed all site maintenance and calibration and data processing responsibilities. Procedures now followed by PNL are described at the end of this section.

\subsection{CALIBRATION AND MAINTENANCE}

The subcontractor provided routine calibration and maintenance services, as we11 as emergency maintenance services, at each site that received DOE equipment. For example, when a utility representative reported a sensor or logger failure, the subcontractor proceeded to the site within 72 hours to correct the problem (in some instances, the problem could be identified and corrective procedures implemented by discussing the situation with the utility representative over the telephone).

The subcontractor also performed calibrations at each of the sites. Annually, calibrations included changing all sensors with precalibrated spares. Quarterly onsite calibrations of all electronics were performed. The precalibrated wind speed sensors were calibrated in a wind tunnel. (WSSI utilized the Colorado State University wind tunnel facilities at Fort Collins, Colorado; ESC used the NOAA Atmospheric Turbulence and Diffusion Laboratory (ATDL) wind tunnel at Oak Ridge, Tennessee; and E-S used the wind tunnel facilities at MRI, Inc., Altadena, California). All calibrations were traceable to standards established by the National Bureau of Standards.

\subsection{SITE MAINTENANCE, DATA EDITING, AND REDUCTION}

At the operational sites, a representative of the utility visited the tower site weekly and changed the cassette tape in the data logger every other week, except at turbine sites where cassettes were changed weekly. Before June 1981, the data-filled cassette was mailed to PNL's subcontractor. 
The utility representative also visually inspected the tower and sensors, checked the performance of the logger, replaced the rechargeable batteries as needed, and filled out a site inspection form that was also mailed to the subcontractor or PNL. Completion of the site inspection form was an important part of both the maintenance and data editing portion of the program. On this form the utility representative was asked to note existing meteorological conditions occurring at the site as well as readings from the various data channels of the data logger. This information aided the subcontractor and PNL meteorologists in determining if a possible equipment failure had occurred or appeared likely and the approximate time during the month the problem occurred. The latter information was valuable in processing and editing the data from the cassette tape.

PNL's subcontractor utilized a computer program to convert the data on the cassette data tapes to engineering units. These data were then edited by a computer program to determine if

- time was less than 2358 and increments were in steps of two minutes

- Julian date recorded on the tape was within the expected range for the month and increments each day

- recorded wind speeds did not change by large values for succeeding two-minute scans, or over each hour

- wind speed values increased with height

- the recorded wind direction did not vary by more than $60^{\circ}$ with wind speeds greater than $5 \mathrm{mph}$.

If any of these conditions occurred, an appropriate message was printed out along with the particular scan in question and a meteorologist reviewed this listing to determine if the data should be changed or coded as missing. Later, PNL requested the subcontractor to code as missing values the obvious bad data and to flag questionable data by a lettering scheme that was coded along with each data scan within the magnetic tape. Once the data were properly edited, they were put on a nine-track tape, a copy of which was forwarded to PNL for analysis. 
The subcontractors were also required, as part of their quality assurance program, to perform a routine "dummy data analysis" on al1 computer programs that were involved in data processing. This procedure would document that the individual computer programs were performing as expected. This technique is commonly used in quality assurance procedures involving data collection at nuclear reactor facilities (Sandusky and Conley 1979).

\subsection{DATA REPORTING}

When the edited monthly nine-track data tape was received at PNL, it was put into a data analysis program, which provided summaries of pertinent wind characteristics at each candidate site. These summaries were incorporated into monthly candidate wind turbine site data reports, which were forwarded to NASA/Lewis, DOE, and each participating utility, thereby allowing an assessment of the wind energy potential at the sites. These reports contained information on

- sensor performance

- monthly means of wind speed and wind direction

- maximum recorded two-minute wind speed value at each level

- mean hourly wind speed and direction versus time-of-day

- a frequency distribution of wind speed

- cumulative frequency distribution of wind speed

- wind speed persistence frequency

- average power law exponent by wind direction

- turbulence intensity versus wind direction

- wind rose plot.

In addition, annual and five-year candidate wind turbine site data reports are published (Sandusky and Renne 1981a, 1981b; Sandusky et al. 1982), which are available from the National Technical Information Service (NTIS). These reports differ from the monthly data reports in that the two-minute data are first used to create hourly averages before the final analyses are made. This is required because of the vast amount of two-minute data collected at the sites over a period of a year. Data from the 17 original sites have also been summarized by Sandusky and Buck (1981). 


\subsection{QUALITY ASSURANCE}

A Quality Assurance (QA) program, similar to that required by the United States Nuclear Regulatory Commission (USNRC), was established for the MVP. The objectives of the $Q A$ program were to ensure that all procedures for calibration, maintenance, and data reduction were carefully followed and results documented. The QA program required, for example, that PNL subcontractors verify that the engineering units created from the cassette data tapes were accurate conversions of the sensor output values as recorded on the tapes. A key element of the QA program was the filing of Nonconformance Reports, which documented the apparent time and type of any component failure and the steps taken to remedy the situation.

PNL's subcontractors designated a QA officer who ensured that all QA procedures were strictly followed. The $Q A$ officer was not directly associated with the calibration, maintenance, and data reduction activities and therefore retained a more independent, unbiased perspective of the program.

\subsection{CURRENT PROGRAM AND DATA BASE DEVELOPMENT}

In June of 1981 all site maintenance and calibration procedures and data processing functions were taken over by PNL. This was done in anticipation of a phase-out of the candidate site program. The calibration and maintenance activities were assumed by PNL technicians; however, the utility personnel who visited the sites periodically also contributed significantly to routine maintenance activities. For example, since the instrument elevator systems allowed the sensors to be brought down to ground level for routine change-out, and PNL supplied spare data loggers to each utility, it was simple for utility personnel to replace and return any damaged equipment to PNL for repairs. This also greatly reduced down time. Al though data recovery rates have suffered somewhat since the 72-hour emergency maintenance procedure was discontinued (rates that had been upwards of $90 \%$ dropped to below $80 \%$ in some cases), these procedures have permitted conservation of program funds without drastic losses in usable data. 
Perhaps the biggest advantage in this revised program management format has been in processing and reporting the data. The current data processing procedure, which has been in place at PNL since June 1981, bypasses the need to translate the cassette tapes onto a nine-track tape. Instead, as the cassettes are received at PNL from the participating utilities, they are read directly into a computer system and stored on a disk. The editing and processing are performed routinely as one step; when a monthly file of data has been assembled, a monthly data analysis report can be produced. This procedure has greatly increased processing efficiency, decreased the turnaround time for producing individual monthly reports, and has allowed the creation of a comprehensive candidate site data base. This data base has proved invaluable for performing special analyses and for responding to numerous data requests.

The data editing procedure was streamlined so that data were edited, coded as missing if required, and converted to engineering units by one computer program. This procedure, which had been suggested by the PNL subcontractors, was required because of the large volume of data to be processed once all sites were operational. As the data were processed, any values changed to a missing code were listed as part of the program. These 1istings were reviewed by a PNL meteorologist to determine if any "good" data were being incorrectly changed to a missing code. Generally, the above condition only occurred when abnormal time-of-day or Julian day data were recorded on the cassette tape. In this case the PNL meteorologist, using the text editor of the computer, could locate the abnormal data scan and delete that scan or change the incorrect value. Since the original data, stored as a binary file, remained on disk, the editing and engineering conversion procedure was repeated and subsequent outputs from the program were again reviewed by the meteorologist. Thus, the editing procedure for some individual tapes required several iterative review and reprocessing steps.

Another innovation that has taken place in the program since June of 1981 has been the installation of remote data transfer systems at some of the sites. These systems store up to 32 hours of hourly data collected at the site, then transmit the data over existing phone lines to a printer or to the 
computer system at PNL. A total of nine units were installed at sites where phone lines were readily available by early 1982, including the MOD-OA turbine installation sites identified in the next section. (a) With the implementation of an automatic dial-up system in the computer, it is possible to maintain a daily file of current data in the computer. This allows for more efficient identification of any problems with the sensors at the sites and allows the data to be used in other wind energy studies, such as wind forecasting studies, where rapid access to the data is required.

(a) Except at the Culebra, Puerto Rico, site 


\section{TURBINE INSTALLATION SITES}

From time to time a candidate site was selected for receiving a large DOE horizontal-axis wind turbine for a cooperative field testing program operated by NASA/Lewis and the utility. Five sites were selected for these first-generation wind turbine experiments during the first two years of the program. These sites, and the type of wind turbine, are summarized in Table 3.

TABLE 3. Large Turbine Installation Sites for Field Testing Selected During the Period 1976-1979

\begin{tabular}{ll}
\multicolumn{1}{c}{ Site } & \multicolumn{1}{c}{ Turbine } \\
Clayton, NM & MOD-OA (rated at 200 kW) \\
Culebra, PR & MOD-OA \\
Block Is land, RI & MOD-OA \\
Kahuku, HI (a) & MOD-OA \\
Boone, NC & MOD-1 (rated at 2000 kW)
\end{tabular}

(a) Data from Kaena Point, Hawaii, were used for the selection in 1978, but for logistical reasons the site was moved to the Kahuku Hills, about $30 \mathrm{~km}$ to the northeast.

In 1978 and early 1979, special modifications to the data acquisition system were made at these turbine sites. At two of the operational MOD-OA sites (Clayton, New Mexico, and Block Island, Rhode Island), a third level of sensors was installed on the towers at the $30-\mathrm{m}(100-\mathrm{ft})$ level (hub height). In addition, the original MRI 1074 wind sensors were replaced with more sensitive Climet Model 011-3 wind speed and Model 012-15 wind direction sensors. The use of these sensors allowed for more detailed turbulence studies at these sites when the loggers were operated at their high-speed data collection rate (one sample every two seconds). This sampling rate has been utilized periodically for research purposes. 
At the Clayton, New Mexico, MOD-OA site, a special array of meteorological towers has been installed to perform additional turbine performance and stress studies on the machine. This research program is also being conducted as part of PNL's Wind Characteristics Program Element (WCPE), but is not directly a part of the MVP.

Another modification to the data acquisition program at the MOD-OA sites was that turbine output parameters (alternator power output, nacelle yaw error, and wind speed and direction from the nacelle anemometer) were recorded simultaneously with the meteorological tower data. This allowed detailed analysis of the turbine's performance and response to the free-stream meteorological conditions at the site.

A 48.8-m (160-ft), free-standing meteorological tower was installed at the Kahuku, Hawaii, MOD-OA site, and data collection began in September 1980. The tower is $60 \mathrm{~m}$ southeast of the turbine. Collection of meteorological data began in late September 1980. At this site, as at the other MOD-OA sites, turbine output parameters were recorded simultaneously with the meteorological tower data.

At the Boone, North Carolina, site, the tower was extended to $85.3 \mathrm{~m}$ $(280 \mathrm{ft})$ in the summer of 1978 so that a warning light could be installed above the MOD-1 blade tip, $83.8 \mathrm{~m}(275 \mathrm{ft})$ above the ground. A third level of sensors was installed at the 76.2-m level on the tower. At this site, as at the other MOD-OA sites, the MRI 1074 wind sensors were replaced with $\mathrm{Cl}$ imet sensors. Turbine output parameters were not recorded on the data logger.

When the candidate site program was expanded in early 1980, the Goodnoe Hills, Washington, site was selected to receive the cluster of three MOD-2 2500-kW wind turbines, which represent the second generation of wind turbine technology developed by DOE and NASA/Lewis. The measurement program at this site was greatly modified to meet the needs of the numerous test procedures that have been planned for this facility. Description of this program is beyond the scope of this report. 


\section{SUMMARY OF FIELD EXPERIENCE}

A detailed summary of the data collected in this program cannot be given here. Reports of annual summarized data have been prepared and are listed as references. However, to provide an idea of the type of wind resource that exists at each of the sites, Table 4 summarizes the mean annual wind speed at the 45.7-m level at all sites involved in this program since its beginning. Since the actual data collection period varied from site to site, the reader should refer to Tables 1 and 2 to determine when the measurements started and ended at each site.

The basic purpose of this program was to obtain wind resource data at promising sites to determine their suitability for operating and field testing large wind turbines. Given this objective, the program was originally designed to obtain reliable data that would document, in climatological terms, the wind resource. Considerations of such parameters as the detailed turbulence structure of the atmosphere and the thermal structure as it relates to stability were beyond the scope of this program. For this reason, the sampling scales were kept long, and highly responsive sensors were sacrificed for rugged and durable equipment.

As the program evolved, however, the need for more refined turbulence data became apparent because of possible structural problems the machines might encounter. Therefore, the more rugged equipment used earlier in the program was replaced by more responsive sensors. In addition, as the size of the program increased, a more automated approach for data collection was required, and the strip-chart recorders were replaced by digital cassette data loggers.

These changes allowed for a much more refined data collection system. For example, the loggers had the capability to collect one-second samples, and the highly responsive anemometers were capable of providing detailed turbulence data. However, the basic objective of the program was still to collect climatological-type data, and the responsive characteristics of the data 
TABLE 4. Average Annual Wind Speed, $m / s$ at the $45.7 \mathrm{~m}$ Level at 36 Candidate Sites

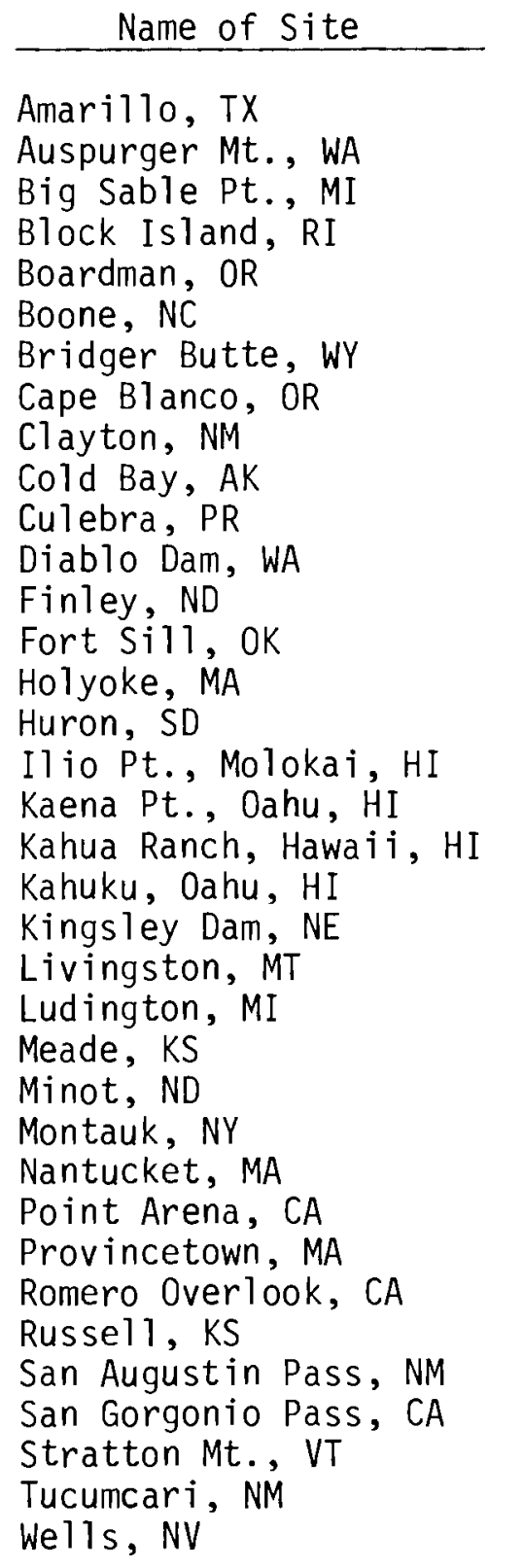

Annual Average Wind Speed, $\mathrm{m} / \mathrm{s}$ at $45.7 \mathrm{~m}$

\begin{tabular}{|c|c|c|c|c|}
\hline 1977 & 1978 & 1979 & 1980 & 1981 \\
\hline 8.3 & 8.0 & 7.6 & 9.1 & 7.7 \\
\hline 8.6 & --- & --- & --- & --- \\
\hline--- &.-- & -- &.-- & 8.8 \\
\hline $7.4(a)$ & $7.4(a)$ & $7.0(a)$ & $7.7(a)$ & $7.4(a)$ \\
\hline $5.9^{(a)}$ & $4.8^{(a)}$ & $5.4^{(a)}$ & $5.6^{(a)}$ & $5.4^{(a)}$ \\
\hline 8.0 & 7.0 & 7.8 & 8.3 & 8.4 \\
\hline-- & --- & --- & -- & 8.5 \\
\hline--- & -- & $=-$ & $=-$ & 7.9 \\
\hline $7.4(b)$ & $7.4(b)$ & $7.3(b)$ & $7.3(b)$ & $7.2(b)$ \\
\hline $9.6^{(D)}$ & $8.3^{(D)}$ & $7.7^{(D)}$ & $7.1^{(D)}$ & $6.4^{(D)}$ \\
\hline 6.9 & 7.1 & 7.4 & 6.7 & 7.1 \\
\hline-- & $\cdots$ & --- & $\cdots$ & 5.6 \\
\hline-- & -- & --- & -- & 9.4 \\
\hline--- & $-\cdots$ & -- & -.- & 9.2 \\
\hline 7.2 & 7.1 & 6.5 & 7.0 & $5.8^{(\mathrm{C})}$ \\
\hline 6.7 & 6.6 & 6.5 & 6.5 & $7.4(\mathrm{c})$ \\
\hline-- & -- & $-\cdots$ & --- & $10.9^{(2)}$ \\
\hline 8.0 & 8.4 & 7.2 & --- & $---(c)$ \\
\hline-- & --- & --- & --- & $11.3(\mathrm{c})$ \\
\hline-- & --- & --- & -- & $8.4^{(1)}$ \\
\hline 6.8 & 7.0 & 6.2 & 6.3 & 6.2 \\
\hline--- & --- & --- & --- & 8.0 \\
\hline 7.6 & $N / A$ & -- & -- & -- \\
\hline--- & -- & --- & -- & 8.0 \\
\hline--- & --- & -- & --- & 8.3 \\
\hline 7.2 & 7.4 & 6.7 & 7.2 & 7.0 \\
\hline--- & --- & -- & -- & $9.1(c)$ \\
\hline 6.7 & 6.8 & 6.4 & 6.0 & $7.1^{(\mathrm{C})}$ \\
\hline$\cdots$ & $-\cdots$ & --- & $\cdots$ & 9.7 \\
\hline--- & --- & --- & --- & 6.1 \\
\hline 7.5 & 7.5 & 7.0 & 6.8 & 7.1 \\
\hline--- & -- & -- & --- & 8.6 \\
\hline 7.9 & 8.1 & 7.2 & 8.1 & $7.1(c)$ \\
\hline-- & -- & -- & -- & $11.4^{101}$ \\
\hline--- & -- & -- & -- & 8.7 \\
\hline--- & -- & --- & --- & 7.9 \\
\hline
\end{tabular}

(a) $39.6 \mathrm{~m}$

(b) $21.8 \mathrm{~m}$

(c) Data recovery less than $40 \%$ 
collection system were only utilized under special circumstances. Additional tradeoffs became apparent as the more sensitive equipment and automated data logging systems were installed. In most cases, windy sites are also sites with harsh environments, and the geographical diversity of this program included a wide range of severity in climates. At sites in tropical and temperate coastal environments, salt spray and excessive moisture challenged the capability of the circuitry of the data logging equipment. At other sites, icing was a frequent wintertime problem, causing repeated failure of the more sensitive cup-and-vane-type anemometers (icing at some sites was so severe that even the rugged equipment used earlier in the program was occasionally damaged and in one case icing caused the failure of a tower). At some sites, wintertime temperatures could be so cold that the microprocessors in the unheated data logging equipment would fail. Because of the remoteness of the sites, it was often difficult for anyone to visit them more than once a week-this occasionally resulted in lost data, since equipment could fail during the time no one was at the site, and the failure would not be detected until the next visit. The remoteness of some sites also resulted in occasional vandalism of the equipment.

Despite these problems, which would be inherent in any data collection program, we were able to obtain a relatively high data recovery rate at most sites. A key factor in this was the cooperation of the utility personnel, who often checked the tower more frequently than required, performed maintenance on their own, and often provided additional security around the tower to minimize vandalism and to increase safety. Much was learned about operating sensitive data logging and anemometry systems in harsh environments through this program, as well as more appropriate ways to sample the data for wind turbine site evaluation. Based on these experiences, the next section lists the major recommendations we can offer at this time on future site evaluation measurement programs. 
. 


\section{RECOMMENDATIONS FOR FUTURE SITE EVALUATION PROGRAMS}

\subsection{TOWER AND EQUIPMENT CONFIGURATIONS}

Based on our experiences in the Meteorological Validation Program, we offer the following recommendations for equipment installations at sites being evaluated for large wind turbine utilization:

- If possible, measurements at least as high as the hub of the machine should be obtained. One, and preferably two additional levels, should be installed to allow data to be extrapolated to the hub height or higher, and to provide important information on the vertical shear characteristics at the site.

- Nevertheless, it is preferable to keep the height of the tower below $62 \mathrm{~m}(200 \mathrm{ft})$, since the Federal Aviation Administration (FAA) requires a beacon light on towers higher than this (in some cases, a beacon light would be required even for shorter towers, and after the turbine is installed a beacon light might be required at the height of the blade tip). The operation of the beacon lights requires ac power and, at least early in the site evaluation stage, electrical power may not be available at the site.

- The climatological conditions at the site should be considered before ordering equipment. If severe gustiness or icing is possible, more rugged sensors should be utilized (at the expense of the capability to obtain long-term, high-resolution turbulence data). If severe moisture could be a problem, special instrument enclosures and circuitry designs should be considered to assure that the data logging equipment stays absolutely dry and operational. If severe cold is a problem, the data logging equipment should be placed in a heated enclosure, or some type of resistance heat element installed in the enclosure.

- It is preferable to install towers at locations where icing conditions are minimized. However, if icing is a problem at a chosen location, 
special care should be taken in the tower installation to ensure that a heavy load of ice will not buckle the tower or cause a guy wire to break loose. In the MVP, some problems were encountered with standard guy grips at sites where severe icing was experienced. Water would work its way inside the grip during thaws, and then expand and loosen the grip during refreezing. The grip should be designed to eliminate this problem.

- Although it is preferable to power the data loggers with ac power, in many cases none will be available. Some type of reliable onsite battery charging system should be a part of the equipment, such as solar cells or windchargers. (These were not available in this program, but would have simplified the utility personnel's weekly procedures.)

- Some type of remote data transfer system is recommended (using telephone lines, communications satellites, or telemetry) and a system to automatically incorporate the data into a computer data base is recommended. This will greatly improve data recovery rates and allow for more efficient site maintenance procedures. Nevertheless, it is still recommended that local people be utilized as much as possible to maintain a visual check on the equipment. An onsite data logger should still be used as a backup recording system.

\subsection{SAMPLING AND DATA PROCESSING PROCEDURES}

In Section 5 we discussed an expanded data collection program at the turbine installation sites. One feature of this program is to provide better guidelines on data collection procedures at sites where turbines could be installed, so that the data base more closely resembles the turbine operating logic. Detailed analysis of data collected at these sites has begun, and at this time we can offer the following preliminary recommendations on data collection procedures (see also Renne and Corotis 1981, Corotis 1982):

- The two-minute instantaneous samples provide an adequate sampling scheme for climatological purposes. However, they do not resemble the logic used by the wind turbines for start-up/shut-down procedures. 
- For machine performance evaluation, some type of data averaging is appropriate. A suggested sampling rate of once every 10 minutes is made, with the following pieces of information recorded:

- a 1-second average wind speed

- a 15-second average wind speed (experience has shown that this correlates well with turbine performance)

- a 1-minute average wind speed (correlating with the sampling procedure followed at routine National Weather Service Stations)

- a 10-minute average wind speed (for machine operating procedures)

- the variance of al1 15-second averages within the 10-minute average

- maximum wind gust during the 10-minute sampling period. 


\section{REFERENCES}

Corotis, R. F. 1982. Statistical Analys is of High-Frequency Wind Speed Characteristics and Wind Turbine Power. PNL-4231, Pacific Northwest Laboratory, Richland, Washington.

Renne, D. S. and W. F. Sandusky. 1979. "DOE Candidate Site Meteorological Measurement Program." Presented at Third Meeting of Experts--Data Acquisition and Analysis for Large-Scale Wind Energy Conversion Systems, Blowing Rock, North Carolina, September 26-29, 1979. Published in Special Report No. 71 of the Central Library of the Nuclear Research Establishment, Jülich, Germany.

Renné, D. S. and R. B. Corotis. 1981. "Assessing the Representativeness of Wind Data for Wind Turbine Site Evaluation." Presented at the Workshop on Wind Characteristics, Cleveland, Ohio, July 28, 1981.

Sandusky, W. F. and R. L. Conley. 1979. "Quality Assurance for a Meteorological Data Acquisition Program." Proceedings of a APCA Specialty Conference on Quality Assurance in Air Pollution Measurements, New Orleans, Louisiana, March 11-14, 1979.

Sandusky, W. F. and D. S. Renné. 1981a. Candidate Wind Turbine Generator Site Annual Data Summary for January 1980 Through December 1980. PNL-3739, Pacific Northwest Laboratory, Richland, Washington.

Sandusky, W. F. and D. S. Renne. 1981b. Candidate Wind Turbine Generator Site Annual Data Summary for January 1979 Through December 1979.

PNL-3703, Pacific Northwest Laboratory, Richland, Washington.

Sandusky, W. F. and J. W. Buck. 1981. "An Analysis of Data from the U.S. Department of Energy's Meteorological Validation Program." Presented at the American Association for the Advancement of Science, Pacific Division, Annual Meeting, Eugene, Oregon, June 15-18, 1981.

Sandusky, W. F., J. W. Buck, D. S. Renné, D. L. Hadley and 0. B. Abby. 1982. Candidate Wind Turbine Generator Site Annual Data Summary for January 1981 Through December 1987. PNL-4283, Pacific Northwest Laboratory, Richland, Washington.

Sandusky, W. F., D. S. Renne and D. L. Hadley. 1982. Candidate Wind Turbine Generator Site Summarized Meteorological Data for December 1976 Through December 1981. PNL-4407, Pacific Northwest Laboratory, Rich1and, Washington. 


\section{APPENDIX}

INFORMATION ON THE LOCATION AND EXPOSURE OF THE METEOROLOGICAL EQUIPMENT AT EACH OF THE CANDIDATE SITES 


\section{TABLE A.1. Pertinent Information on the Location and Exposure of the Original 18 Candidate Sites (a)}

\begin{tabular}{|c|c|c|c|}
\hline Name of Site & Location & Reference USGS MaP & Site Exposure \\
\hline Amarillo, TX & $7 \mathrm{mi}$ NE of Amarillo & $\begin{array}{l}\text { Pleasant Valley, Mayer, } \\
\text { TX }\left(7.5^{\prime}\right)\end{array}$ & $\begin{array}{l}\text { Open grassland; site lies } \\
\text { between } 2 \text { power plants to } \mathrm{N} \\
\text { and } \mathrm{S}\end{array}$ \\
\hline Augspurger Mt, WA & $\begin{array}{l}7 \mathrm{mi} \mathrm{W}, 2 \mathrm{mi} \mathrm{N} \text { of Hood } \\
\text { River, } O R\end{array}$ & Hood River, OR $\left(15^{\prime}\right)$ & $\begin{array}{l}\text { Open clearing in forest of } \\
40-f t \text { trees }\end{array}$ \\
\hline Block Is land, RI & $\begin{array}{l}1 / 2 \text { mi } E \text { of town on Harbor } \\
\text { Road }\end{array}$ & Block Island, RI (7.5') & Hilltop in rolling grassland \\
\hline Boone, NC & $\begin{array}{l}1 \mathrm{mi} N \text { of Boone on Howard } \\
\text { Knob }\end{array}$ & Boone, NC (7.5') & $\begin{array}{l}\text { Forested ridgetop, } 40-\mathrm{ft} \\
\text { trees }\end{array}$ \\
\hline Clayton, NM & $3 / 4 \mathrm{mi} \mathrm{SW}$ of Clayton & Clayton, NM (7.5') & Open grassland \\
\hline Cold Bay, AK & FAA tower, Cold Bay, AK & Cold Bay, AK $\left(60^{\prime} \times 120^{\prime}\right)$ & $\begin{array}{l}\text { Airport location, low bldgs. } \\
\text { nearby }\end{array}$ \\
\hline Culebra, PR & 2 mi $N$ of town & $\begin{array}{l}\text { Culebra and Adj. Is. } \\
\left(6^{\prime} \times 11^{\prime}\right)\end{array}$ & $\begin{array}{l}\text { Top of hill, few shrubs and } \\
\text { low trees }\end{array}$ \\
\hline Holyoke, MA & $\begin{array}{l}4 \mathrm{mi} N \text { of Holyoke near } \\
\text { Mt. Tom }\end{array}$ & Mt. Holyoke, MA (7.5') & $\begin{array}{l}\text { Forested ridgetop, } 50-\mathrm{ft} \\
\text { trees }\end{array}$ \\
\hline Huron, SD & $4.2 \mathrm{mi}$ NE Huron & Huron NW, SD $\left(7.5^{\prime}\right)$ & $\begin{array}{l}\text { Open grassland, slightly } \\
\text { rolling }\end{array}$ \\
\hline Kingsley Dam, NE & $\begin{array}{l}6.5 \mathrm{mi} \text { NE of Ogallala off } \\
\text { SR 61 }\end{array}$ & Ogallala, NE $\left(7.5^{\prime}\right)$ & $\begin{array}{l}\text { Rolling prairie, large lake } \\
\text { to NW }\end{array}$ \\
\hline Ludington, MI & $5 \mathrm{mi} S$ of Ludington & Ludington, MI (15') & $\begin{array}{l}\text { Cliff with scattered } 50-\mathrm{ft} \\
\text { trees }\end{array}$ \\
\hline Montauk, LI, NY & $\begin{array}{l}3 / 4 \mathrm{mi} N \text { of Montauk on } \\
\text { Ocean Science Lab. site }\end{array}$ & Montauk Pt., NY $\left(7.5^{\prime}\right)$ & $\begin{array}{l}\text { Rolling sand dunes, bldgs. } \\
\text { to } \mathrm{NE}\end{array}$ \\
\hline Point Arena, $C A$ & $\begin{array}{l}7 \mathrm{mi} \mathrm{N} \text { of town of } \mathrm{Pt} \text {. } \\
\text { Arena, I mi W of SR } 1\end{array}$ & Pt. Arena, CA (7.5') & $\begin{array}{l}\text { Flat grassland, } 50-\mathrm{ft} \text { cliff } \\
\text { l/4 mi W }\end{array}$ \\
\hline Russe 11, KS & $\begin{array}{l}2.5 \mathrm{mil} S \text { of Russell off } \\
\text { US } 281\end{array}$ & Homer, KS (7.5') & Flat prairie \\
\hline $\begin{array}{l}\text { San Gorgonio Pass, } \\
\text { CA }\end{array}$ & $9 \mathrm{mi} N W$ of Palm Springs & $\begin{array}{l}\text { Desert Hot Springs, CA } \\
\left(7.5^{\prime}\right)\end{array}$ & Flat desert, hill $1 \mathrm{mi} \mathrm{W}$ \\
\hline Boardman, OR & $\begin{array}{l}10 \mathrm{mi} \text { SSW of Boardman off } \\
\text { Tower Road }\end{array}$ & Ella, OR $\left(7.5^{\prime}\right)$ & Open, flat prairie \\
\hline Kaena Pt., HI & $32 \mathrm{mi} \mathrm{NW}$ of Honolulu & Kaena, HI (7.5') & $\begin{array}{l}\text { Ridgetop with scattered } \\
\text { shrubs, surrounded by cliffs } \\
\text { except } \mathrm{NE}\end{array}$ \\
\hline Kahuku, HI & $2.5 \mathrm{mi} \mathrm{NW}$ of Kahuku & Kahuku, HI (7.5') & $\begin{array}{l}\text { On hilltop, MOD-OA } 200 \mathrm{ft} \\
\text { to the } \mathrm{N}\end{array}$ \\
\hline
\end{tabular}

(a) Includes Kahuku, which replaced Kaena Pt. 


\section{TABLE A.2. Pertinent Information on the Location and Exposure of the 18 New Candidate Sites}

\begin{tabular}{|c|c|c|c|}
\hline Name of Site & Location & Reference USGS Map & Site Exposure \\
\hline Big Sable Point, MI & $8 \mathrm{mi} \mathrm{N}$ of Ludington, MI & Manistee, MI (15') & Low rolling sand dunes \\
\hline Bridger Butte, WY & $5.6 \mathrm{mi} \mathrm{SW} \mathrm{Ft.} \mathrm{Bridger,} \mathrm{WY}$ & Ft. Bridger, WY $\left(7.5^{\prime}\right)$ & $\begin{array}{l}\text { Flat, barren mesa, cliffs } \\
200 \mathrm{ft} \text { to } \mathrm{W} \text { and } \mathrm{S}\end{array}$ \\
\hline Cape Blanco, OR & $\begin{array}{l}5 \mathrm{mi} \text { NW Port Orford, OR, } \\
\text { off Cape Blanco Hwy. }\end{array}$ & Cape Blanco, OR (15') & $\begin{array}{l}\text { Open clearing in rolling } \\
\text { woodland, exposed to ocean } \\
\text { toward NW }\end{array}$ \\
\hline Diablo Dam, WA & $\begin{array}{l}1 / 4 \text { mi } W \text { of Diablo Lake } \\
\text { Resort in North Cascades } \\
\text { N.P. }\end{array}$ & Ross Dam, WA (7.5') & $\begin{array}{l}\text { Heavily forested }(40-\mathrm{ft} \\
\text { trees) hilltop }\end{array}$ \\
\hline Finley, NO & $\begin{array}{l}\text { NW corner Finley AFB, } \\
1.5 \mathrm{mi} W \text { of Finley, ND }\end{array}$ & Finley, ND $\left(7.5^{\prime}\right)$ & $\begin{array}{l}\text { Open grassland, bldgs. } 500 \mathrm{ft} \\
\text { to } E\end{array}$ \\
\hline Fort Sill, OK & $\begin{array}{l}S \text { end of Army Base ( } 3 \mathrm{mi} \mathrm{N} \\
\text { of Lawton, OK) }\end{array}$ & Fort Sill, OK (7.5') & Flat, open grassland \\
\hline Il io Pt., HI & $\begin{array}{l}18 \mathrm{mi} N W \text { of Kaunakakai on } \\
\mathrm{NW} \text { end of Molokai }\end{array}$ & Ilio Pt., HI (7.5') & $\begin{array}{l}\text { Opening, with scattered } \\
\text { shrubs, cliffs to } E \text { and NE }\end{array}$ \\
\hline Kahua Ranch, $\mathrm{HI}$ & $\begin{array}{l}10 \text { mi NW of Waimea, Island } \\
\text { of Hawaii }\end{array}$ & Kawaihae, HI (7.5') & Rolling grassy ranchland \\
\hline Livingston, MT & $2.8 \mathrm{mi} \mathrm{E}$ of Livingston, MT & $\begin{array}{l}\text { Livingston, Mission Mt. } \\
\left(7.5^{\prime}\right)\end{array}$ & $\begin{array}{l}\text { slightly rolling, ranch } \\
\text { land, rising hilis to } S\end{array}$ \\
\hline Meade, KS & $1.9 \mathrm{mi}$ ENE of Meade & Meade, KS $\left(7.5^{\prime}\right)$ & Flat grassland and cornfields \\
\hline Minot, ND & $\begin{array}{l}16 \mathrm{mi} S \text { of Minot on radar } \\
\text { base }\end{array}$ & $\begin{array}{l}\text { Minot Quadrangle, ND } \\
\left(15^{\prime}\right)\end{array}$ & $\begin{array}{l}\text { Hilltop in rolling prairies; } \\
\text { large bldgs. to NE }\end{array}$ \\
\hline Nantucket, MA & $\begin{array}{l}5.9 \mathrm{mi} \text { ESE town of } \\
\text { Nantucket }\end{array}$ & Siasconset, $M A\left(7.5^{\prime}\right)$ & $\begin{array}{l}\text { Open field; shrubs to } N \text {, } \\
\text { bldg. to immediate } N\end{array}$ \\
\hline Provincetown, MA & $0.7 \mathrm{mi} \mathrm{w}$ of Provincetown & Provincetown, MA (7.5') & $\begin{array}{l}\text { Flat clearing in woodland } \\
\text { (30-ft trees) }\end{array}$ \\
\hline Romero Overlook, CA & $\begin{array}{l}26 \mathrm{mi} \mathrm{E} \text { of Gilroy; } 1 / 2 \mathrm{mi} \mathrm{N} \\
\text { S.R. } 152 \text { at Pacheco Pass }\end{array}$ & Pacheco Pass, CA (7.5') & $\begin{array}{l}\text { Partially wooded }(30-\mathrm{ft} \\
\text { trees) ridgetop }\end{array}$ \\
\hline $\begin{array}{l}\text { San Augustin Pass, } \\
\text { NM }\end{array}$ & $20 \mathrm{mi}$ NE of Las Cruces & Orgar, NM $\left(7.5^{\prime}\right)$ & $\begin{array}{l}\text { Steep, westward-facing barren } \\
\text { slope }\end{array}$ \\
\hline Stratton Mt., VT & $\begin{array}{l}38 \text { mi NW of Brattleboro, } \\
V T \text {, on Stratton Ski Area }\end{array}$ & Londonderry, VT $\left(15^{\prime}\right)$ & $\begin{array}{l}\text { Heavily wooded (40-ft trees) } \\
\text { mountain top }\end{array}$ \\
\hline Tucumcari, NM & $3 \mathrm{mi} S W$ at Tucumcari & $\begin{array}{l}\text { Tucumcari, Liberty Mesa, } \\
\text { NM }\left(7.5^{\prime}\right)\end{array}$ & Barren, flat hilltop \\
\hline Nells, NV & $20 \mathrm{mi}$ ESE of Wells & $\begin{array}{l}\text { Pequop Summit, NV } \\
\left(7.5^{\prime}\right)\end{array}$ & $\begin{array}{l}\text { Slightly rolling ridges; } \\
\text { high complex terrain to } S \\
\text { and } N\end{array}$ \\
\hline
\end{tabular}




\section{AMARILLO, TX}
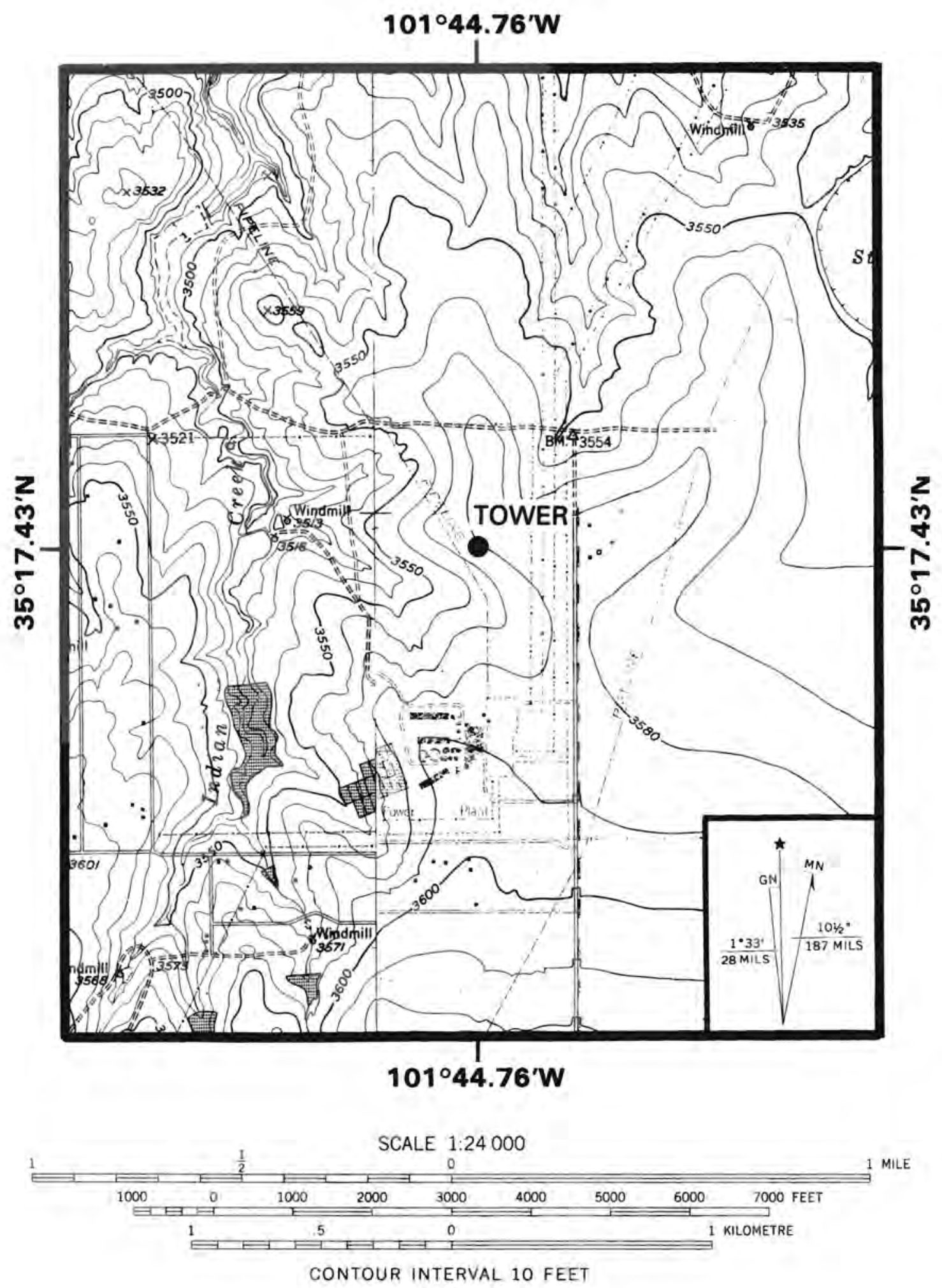


\section{AUGSPURGER MT., WA.}

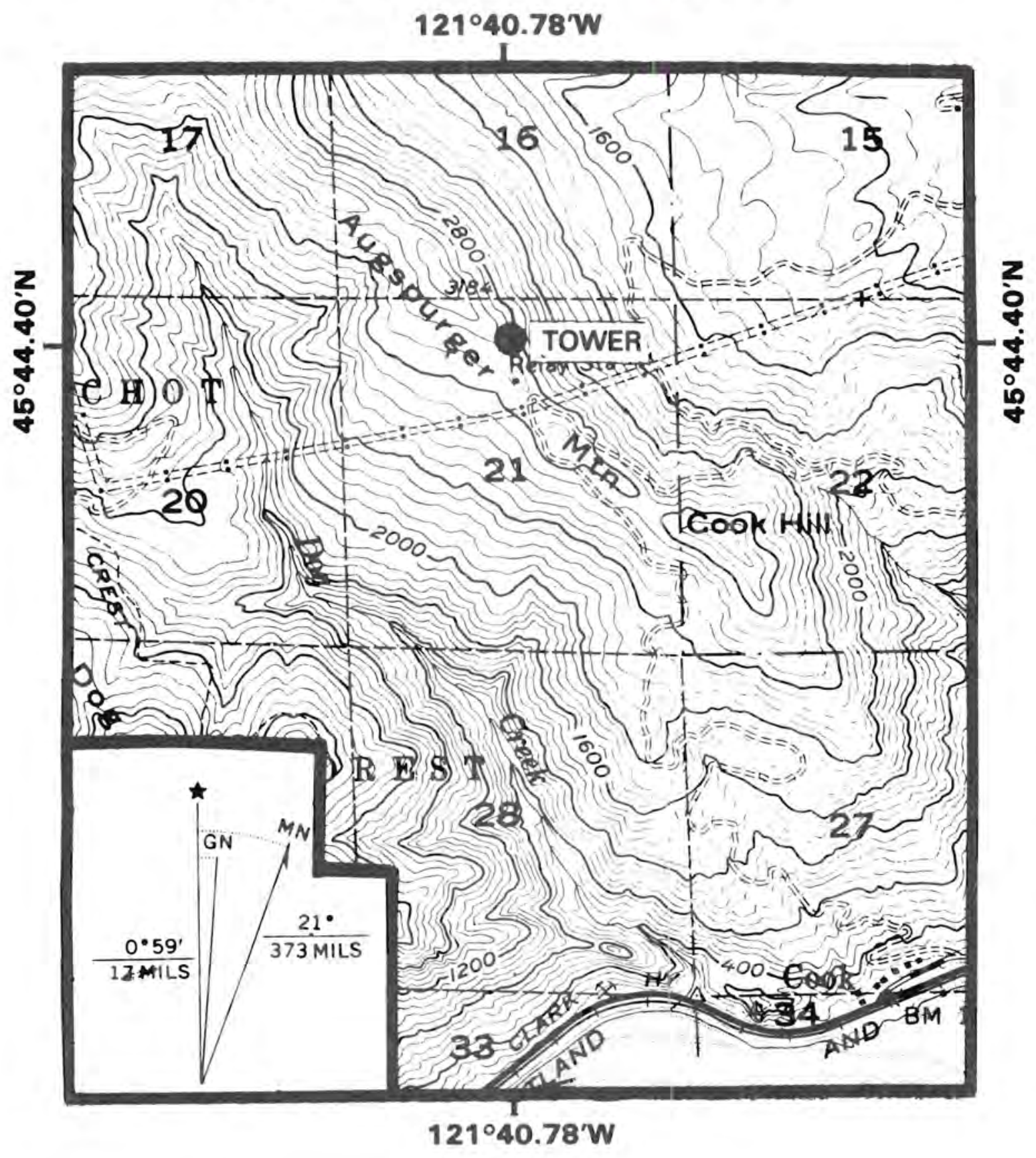

SCALE 1:62500

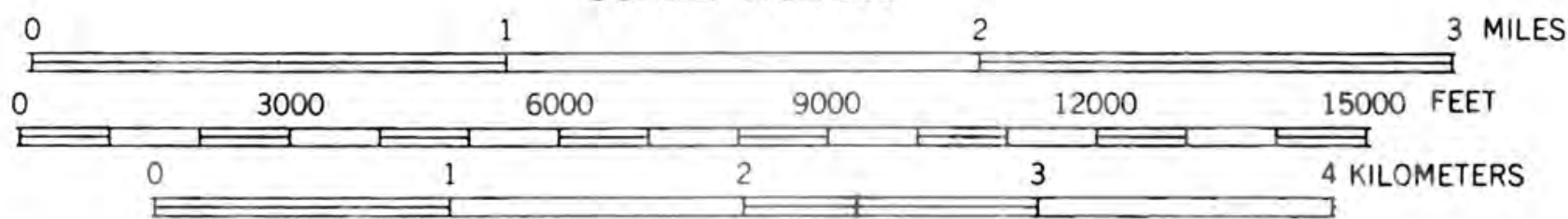

CONTOUR INTERVAL 80 FEET

DOTTED LINES REPRESENT 4O-FOOT CONTOURS

DATUM IS MEAN SEA LEVEL 


\section{BIG SABLE POINT, MI}
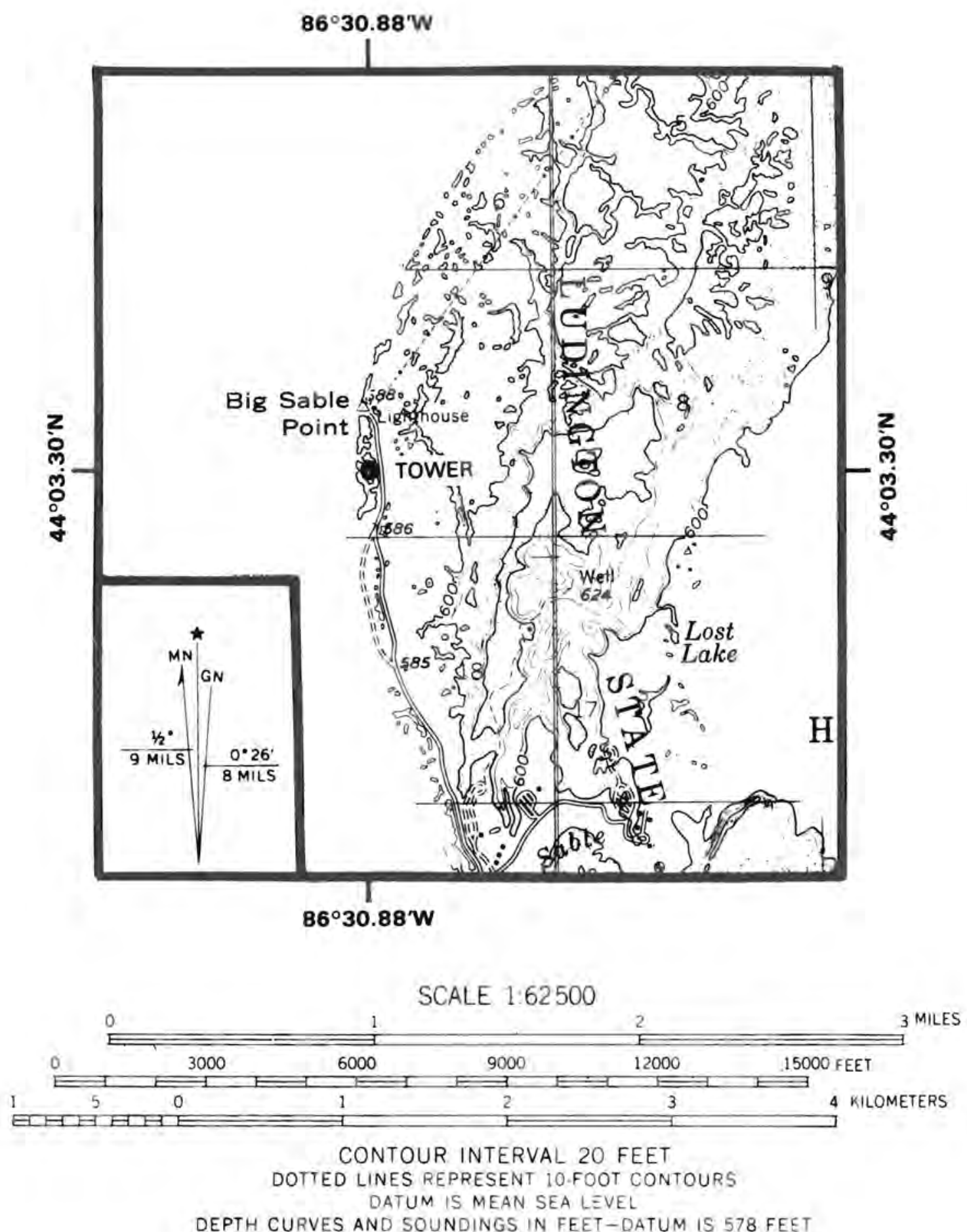


\section{BLOCK ISLAND, R.I.}

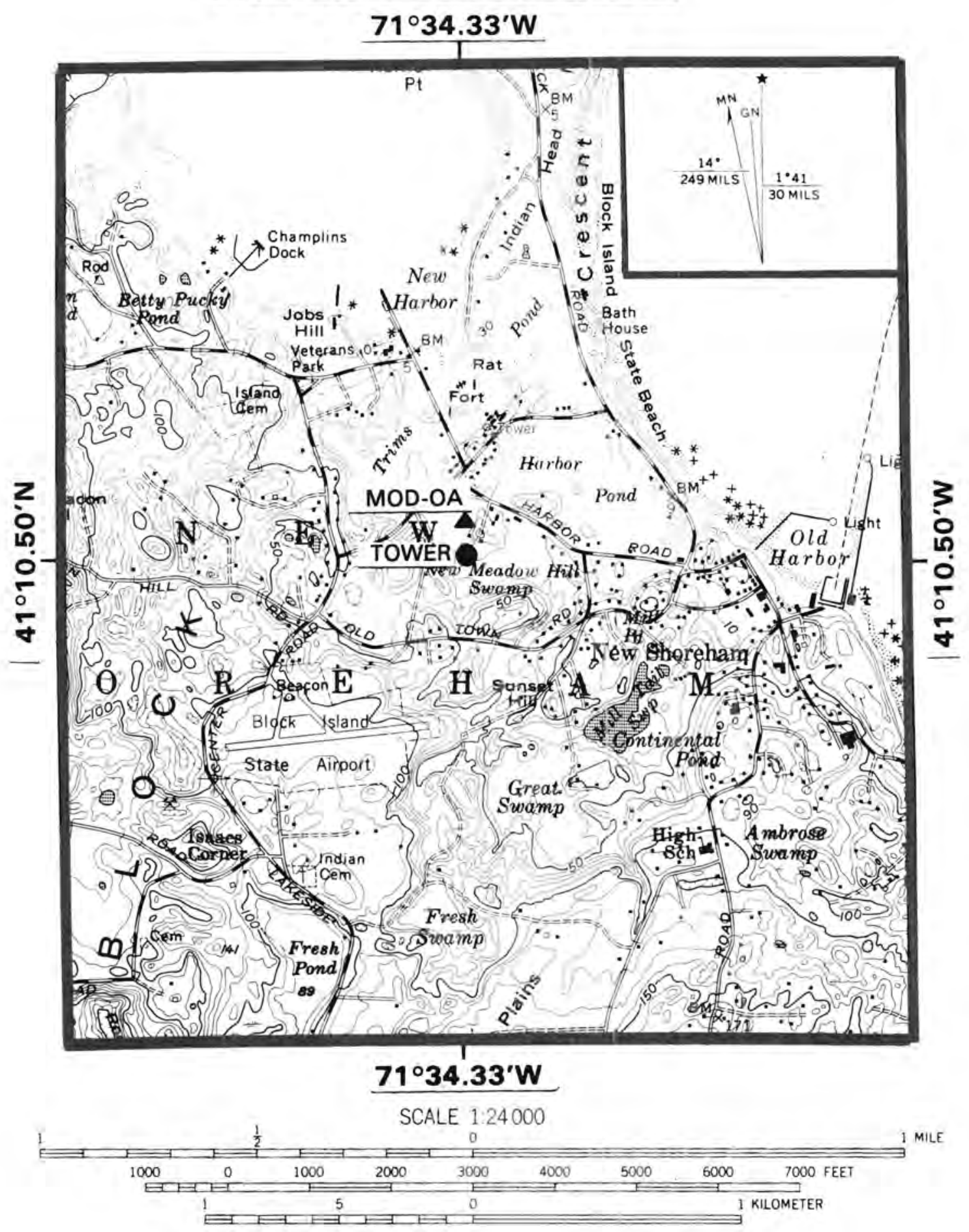




\section{BOARDMAN, OR}
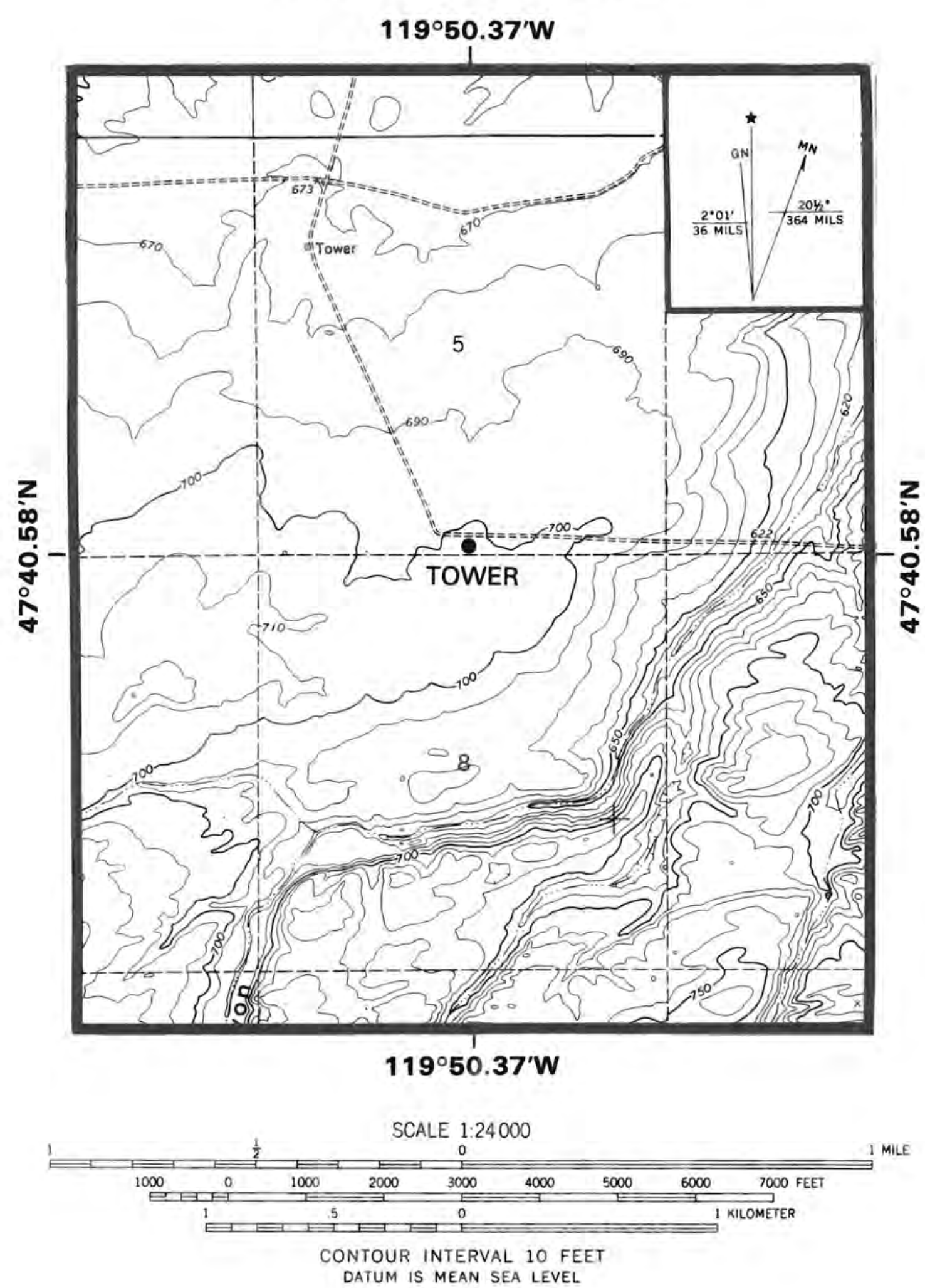


\section{BOONE, N.C.}

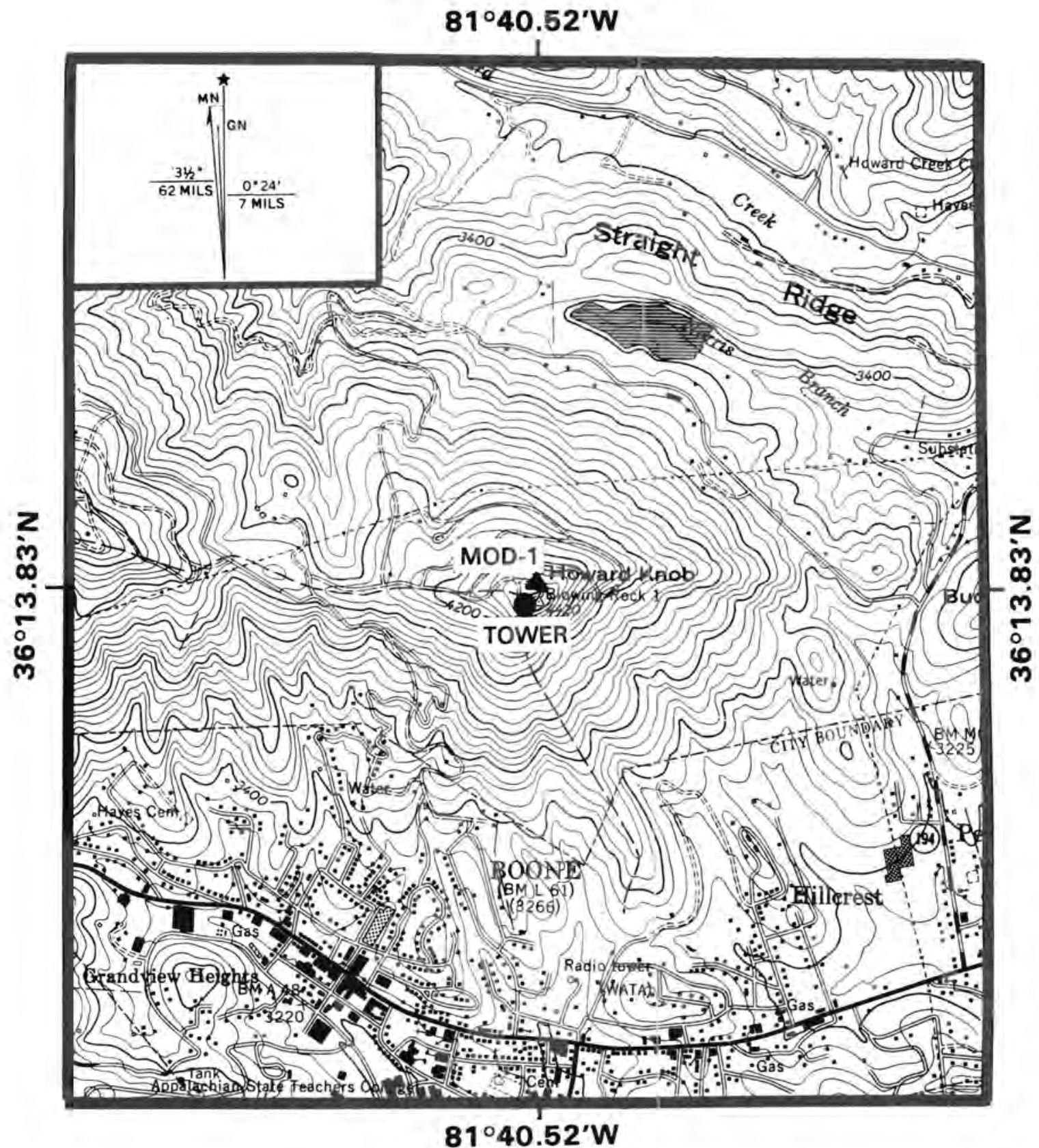

SCALE 1:24000

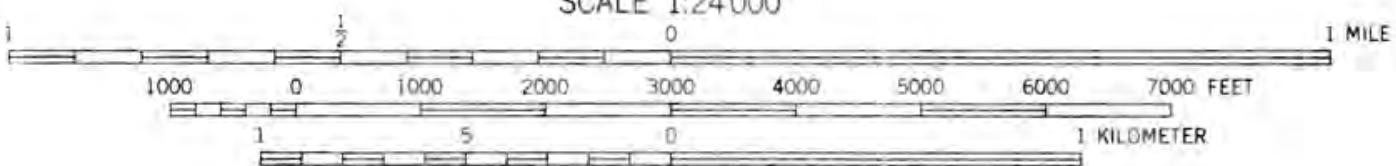




\section{BRIDGER BUTTE, WY}
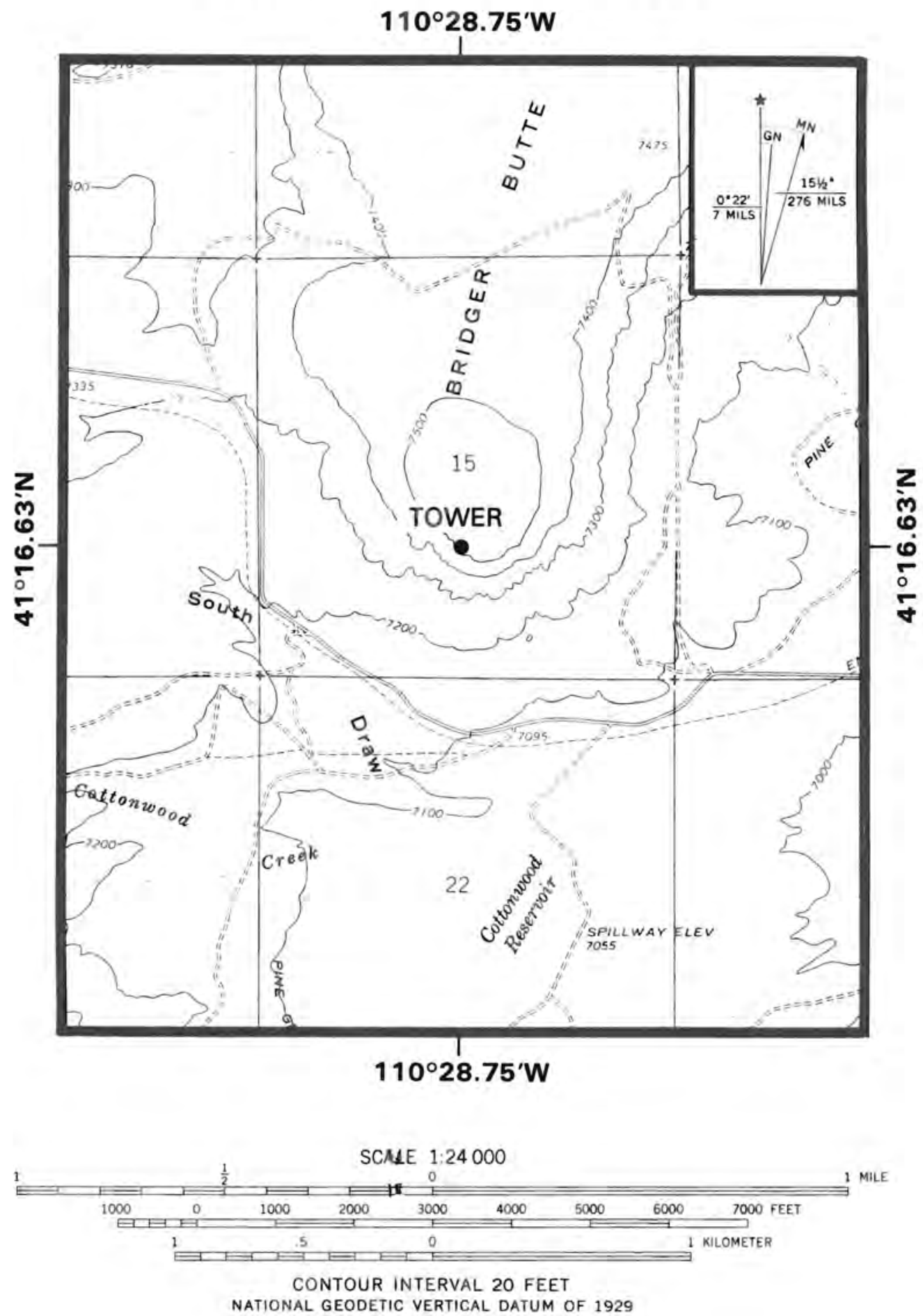


\section{CAPE BLANCO, OR}
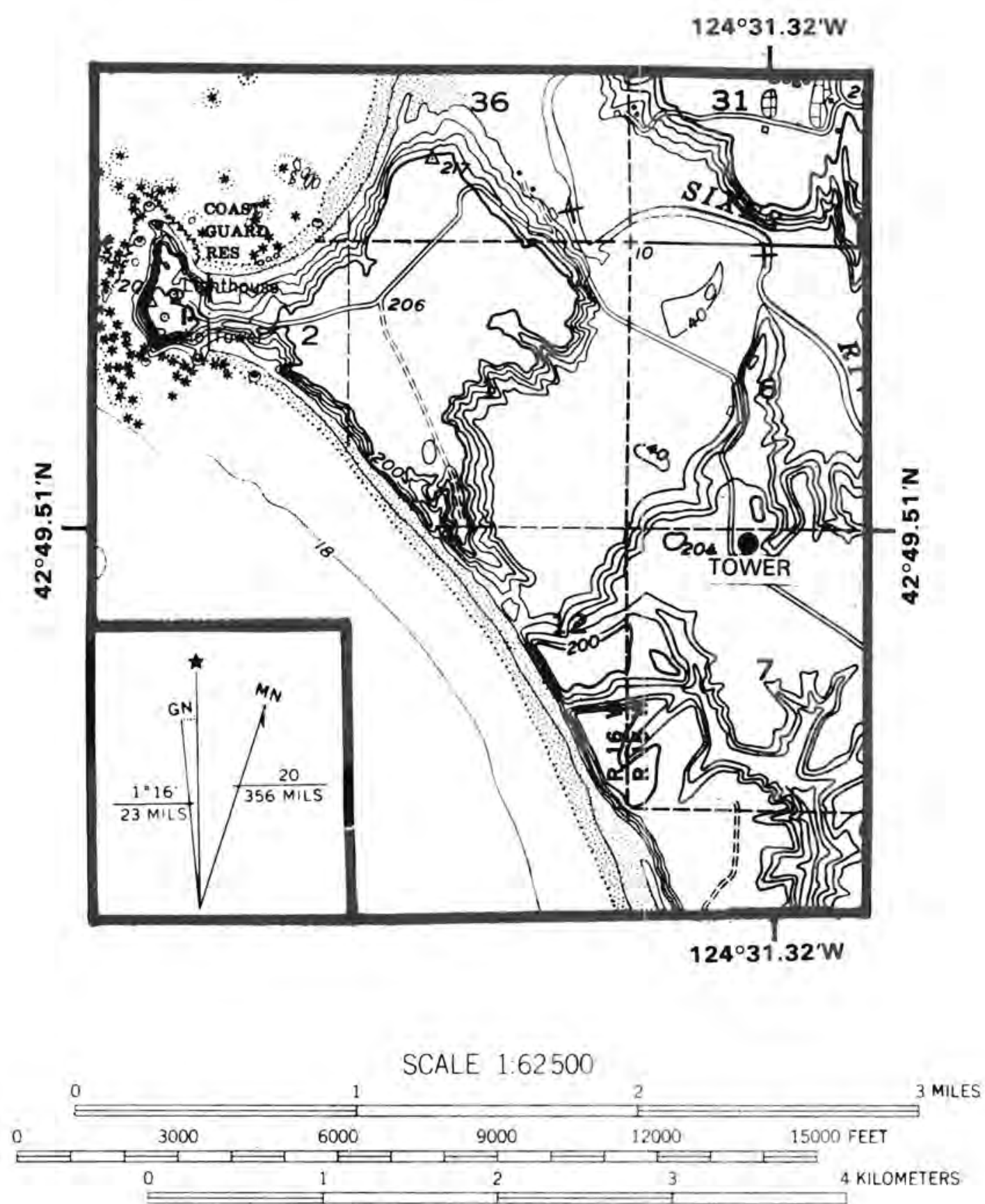

CONTOUR INTERVAL 40 FEET

DATUM IS MEAN SEA LEVEL

DEPTH CURVES IN FEET-DATUM IS MEAN LOWER LOW WATER

SHORELINE SHOWN REPRESENTS THE APPROXIMATE LINE OF MEAN HIGH WATER

THE AVERAGE RANGE OF TIDE IS APPROXIMATELY 5 FEET 
CLAYTON, N.M.

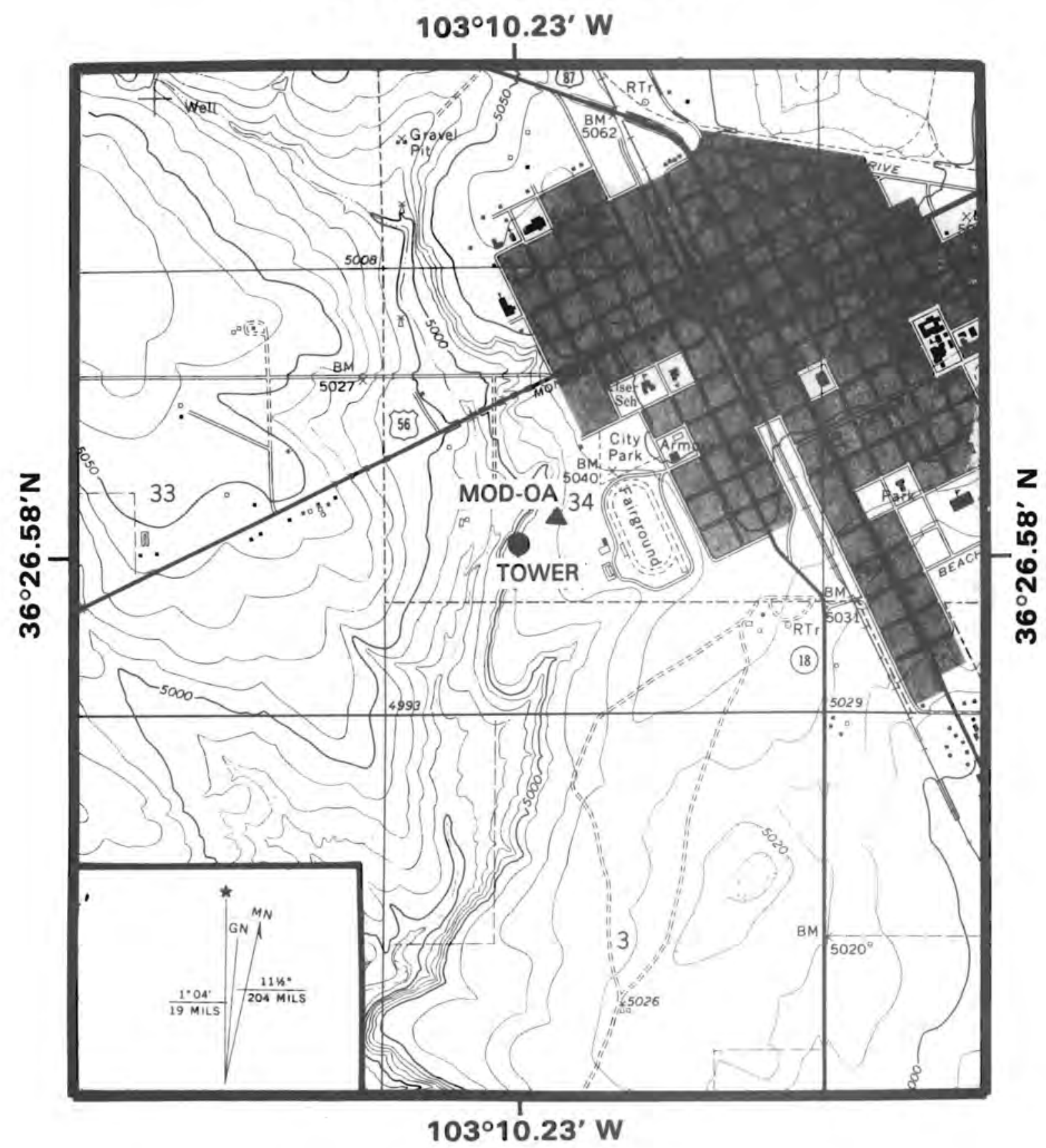

SCALE 1:24000

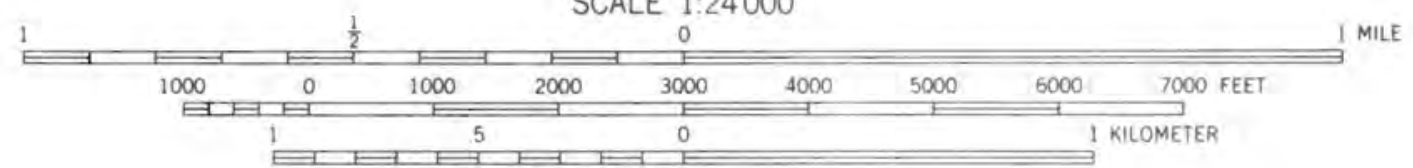




\section{COLD BAY, AK}

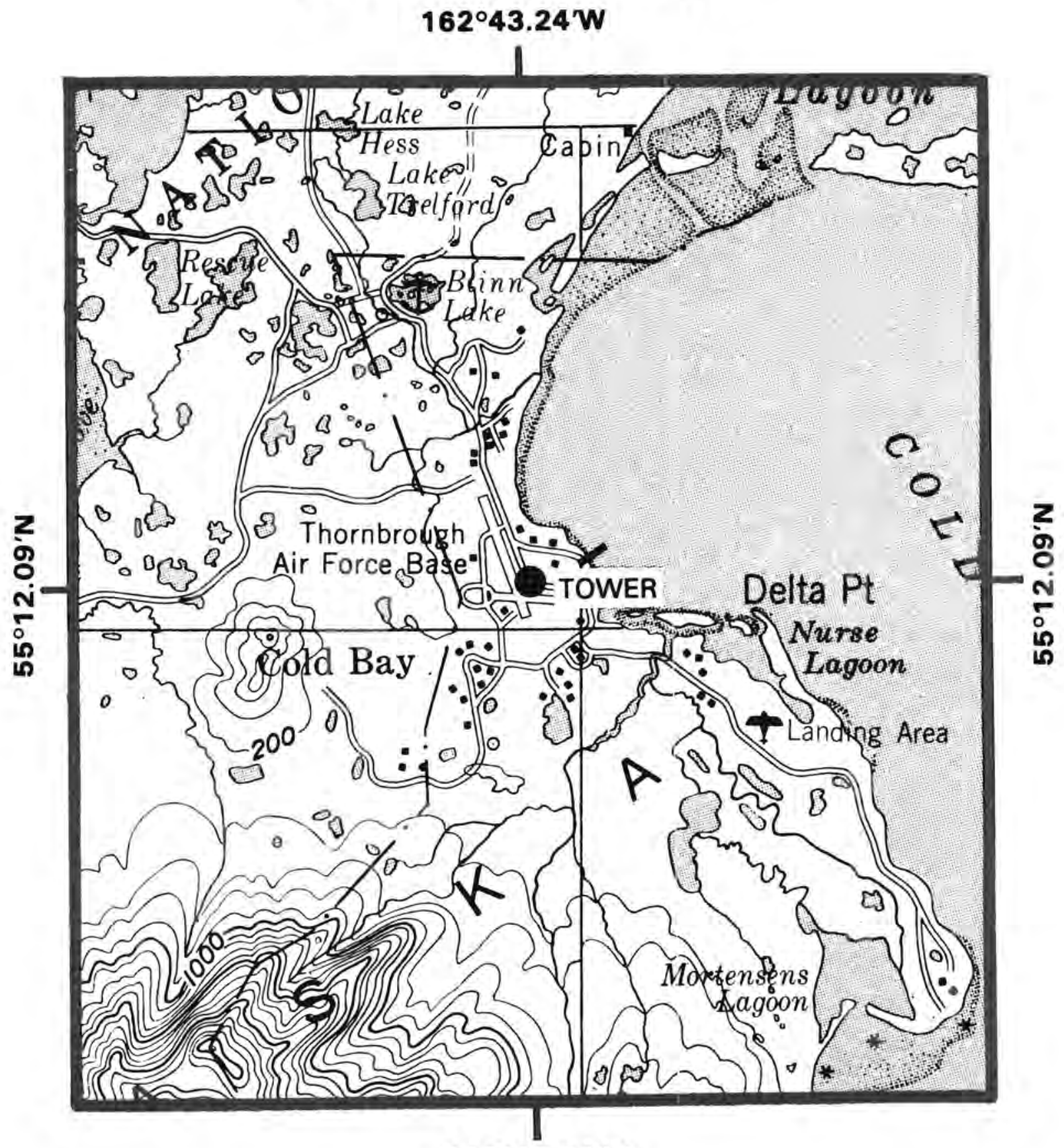

$162^{\circ} 43.24^{\prime} \mathrm{W}$

SCALE 1:250000

0 
CULEBRA, P.R.

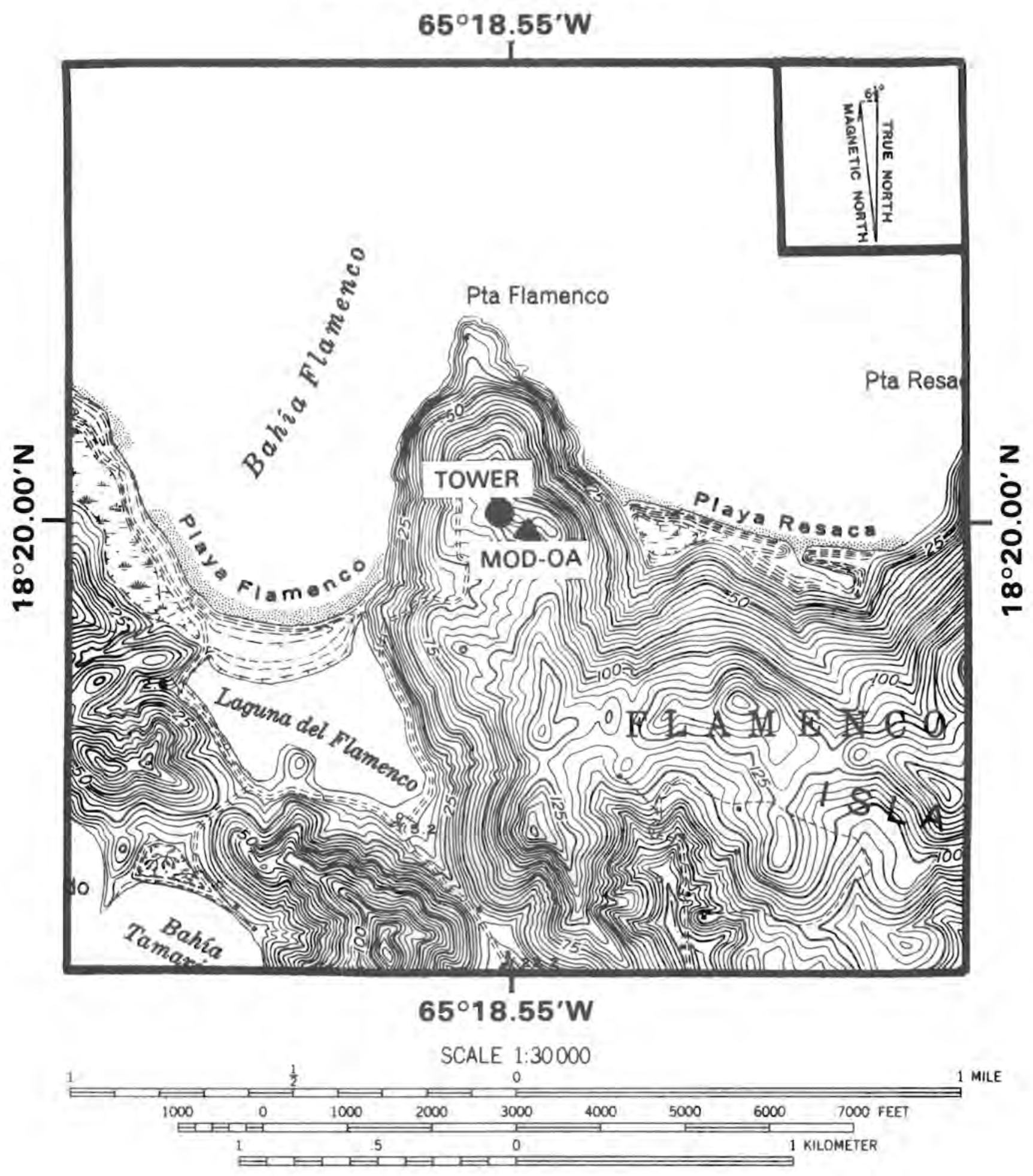




\section{DIABLO DAM, WASHINGTON}

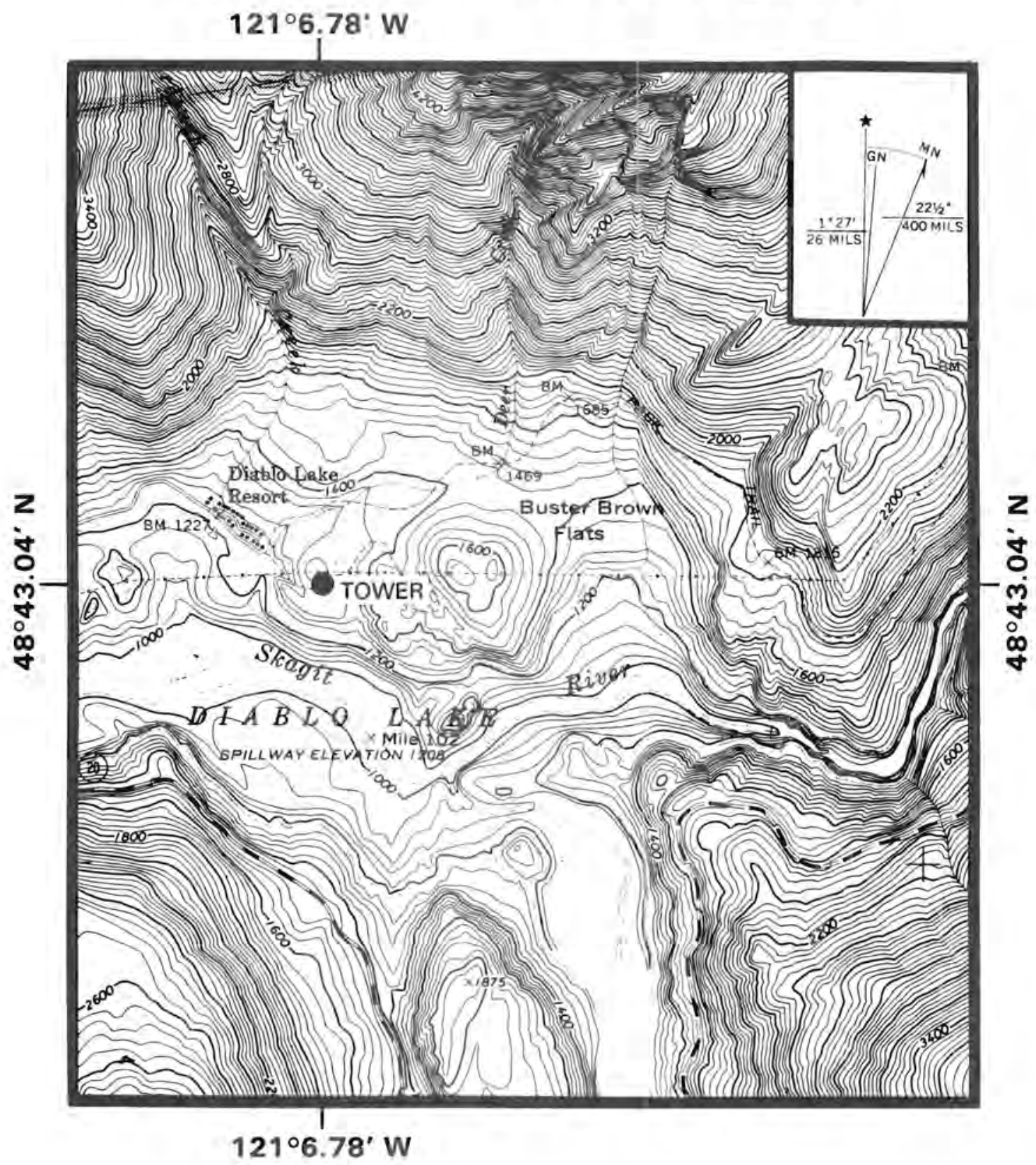

SCALE 1:24000

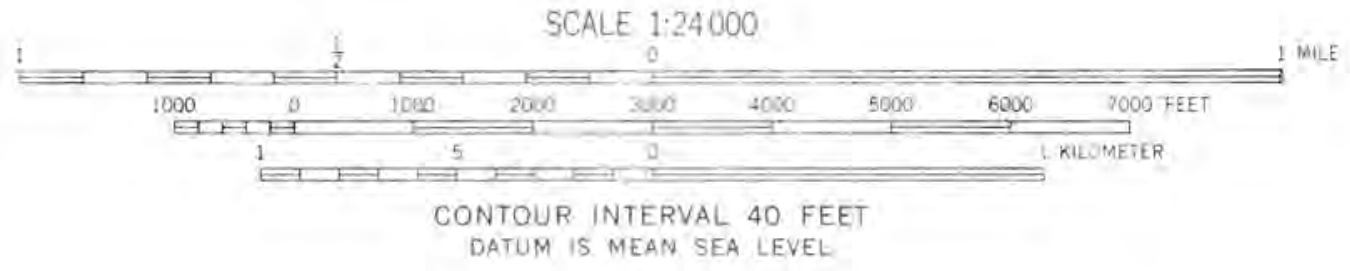




\section{FINLEY AIR FORCE BASE, NORTH DAKOTA}
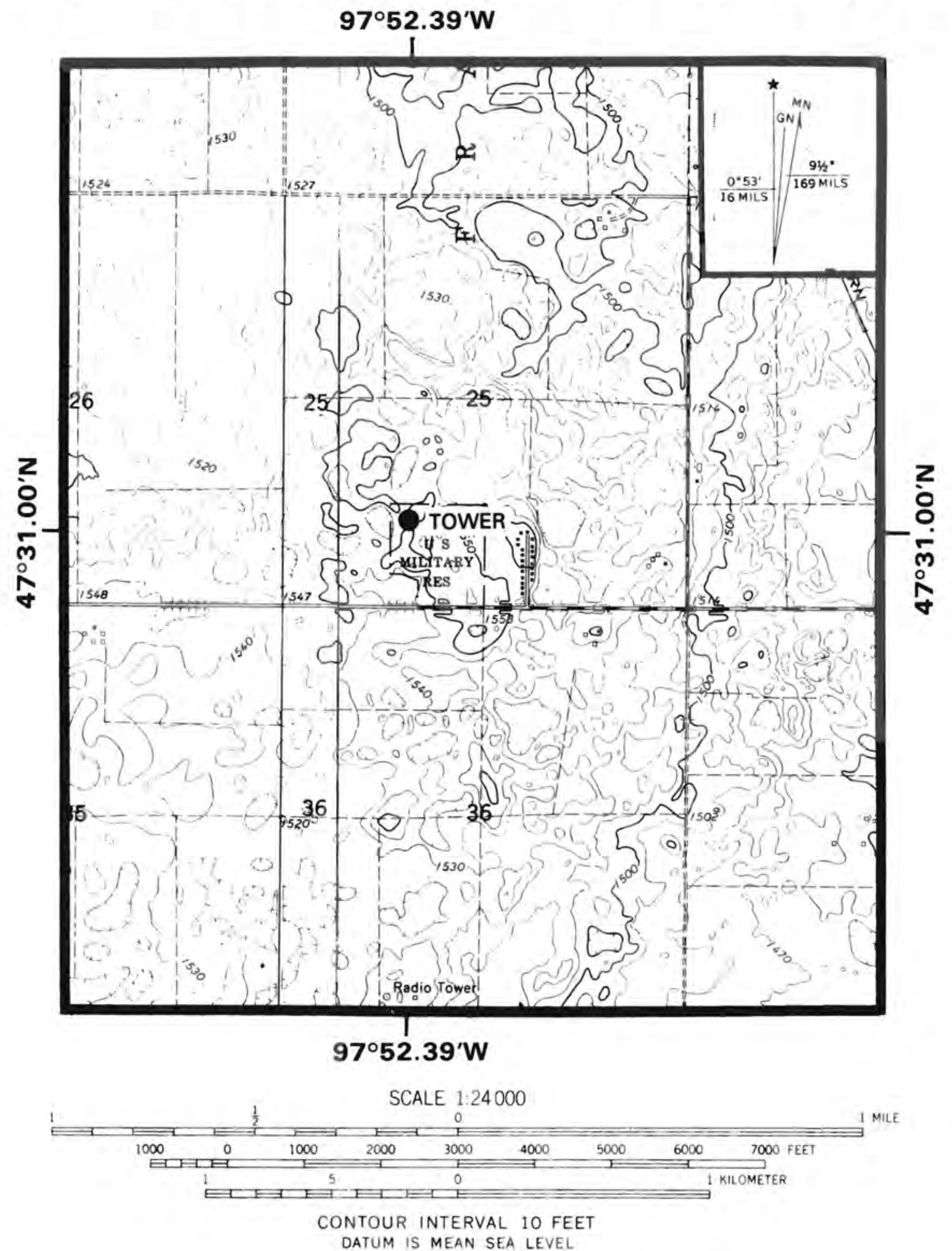


\section{FORT SILL, OK}
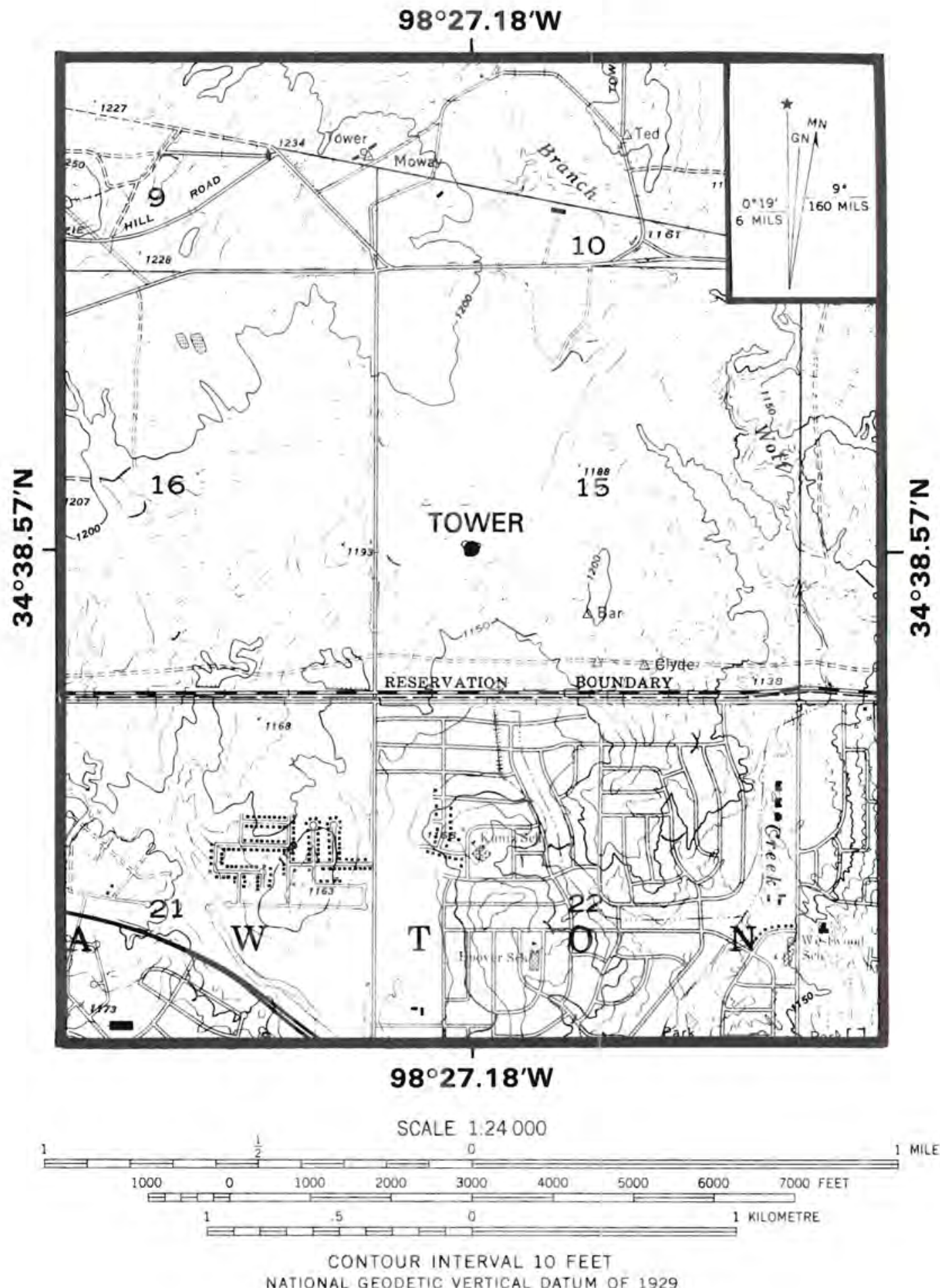


\section{ILIO PT., HAWAII}
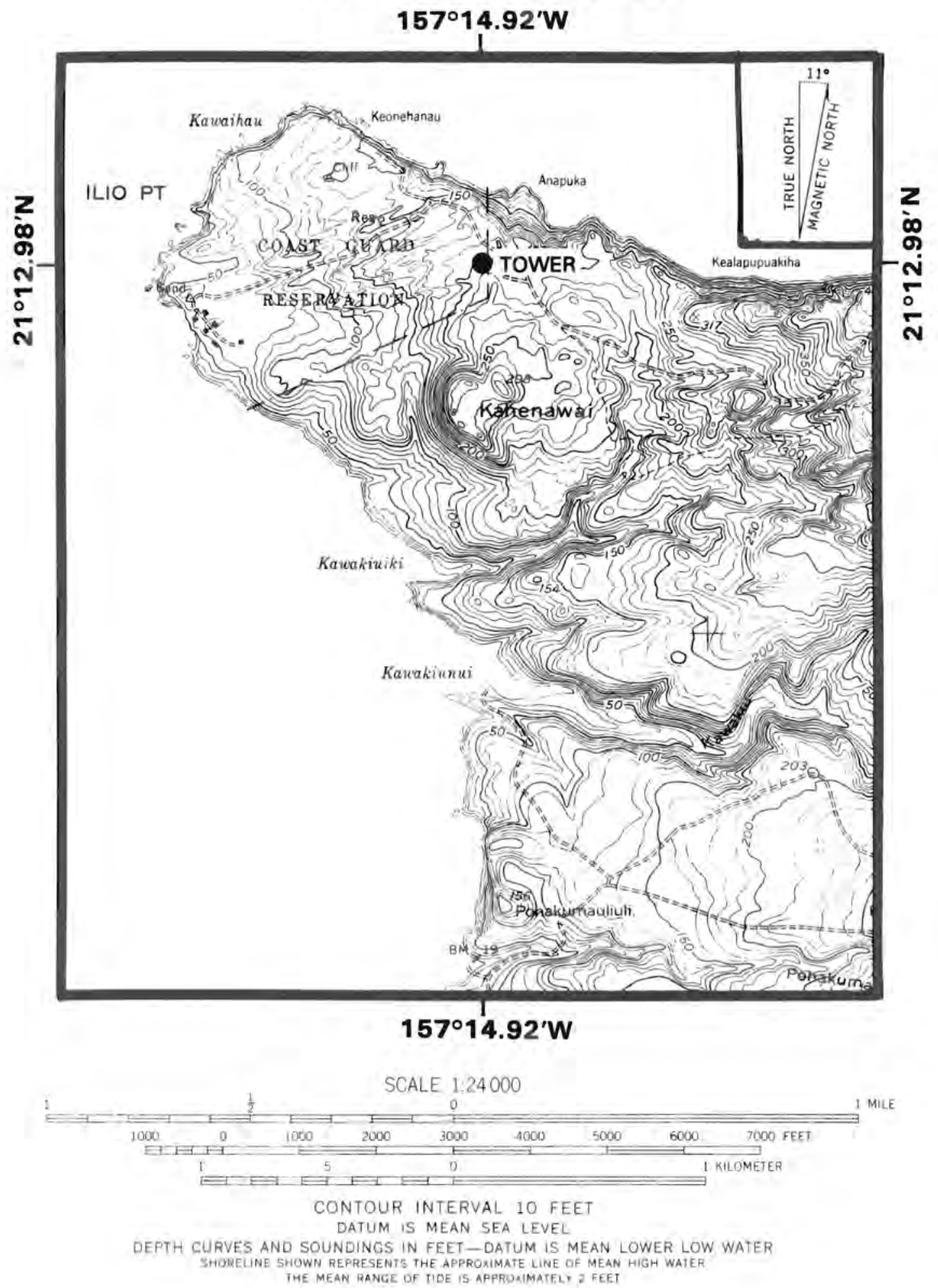


\section{HOLYOKE, MA.}
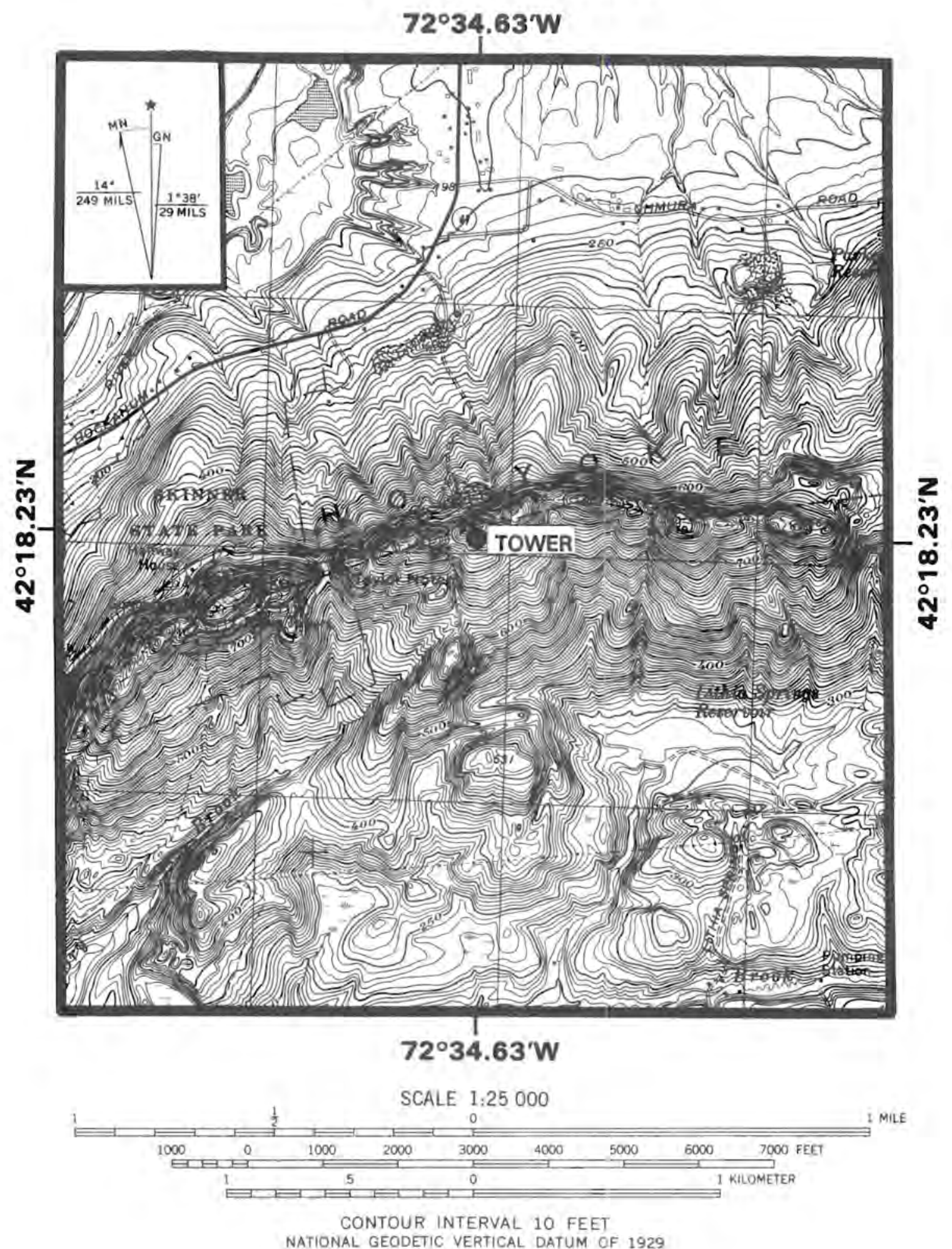


\section{HURON, SOUTH DAKOTA}

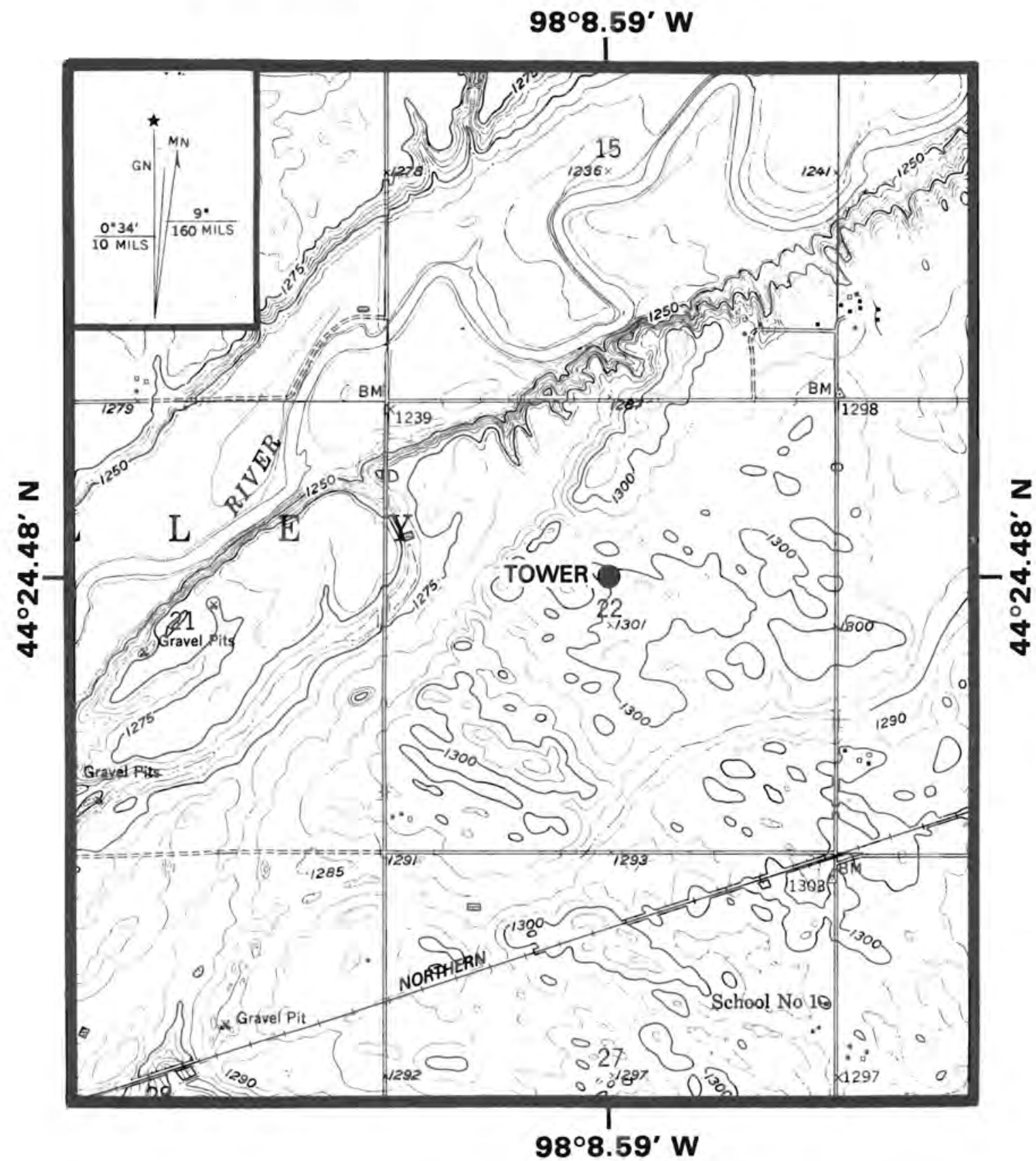

SCALE 1:24000

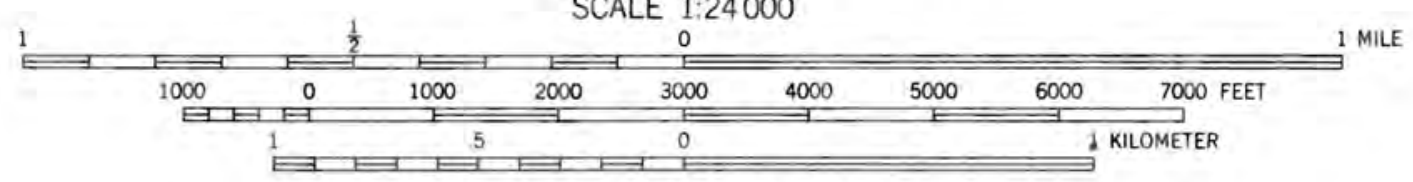

CONTOUR INTERVAL 5 FEET

NATIONAL GEODETIC VERTICAL DATUM OF 1929 


\section{KAHUKU PT, HAWAII}

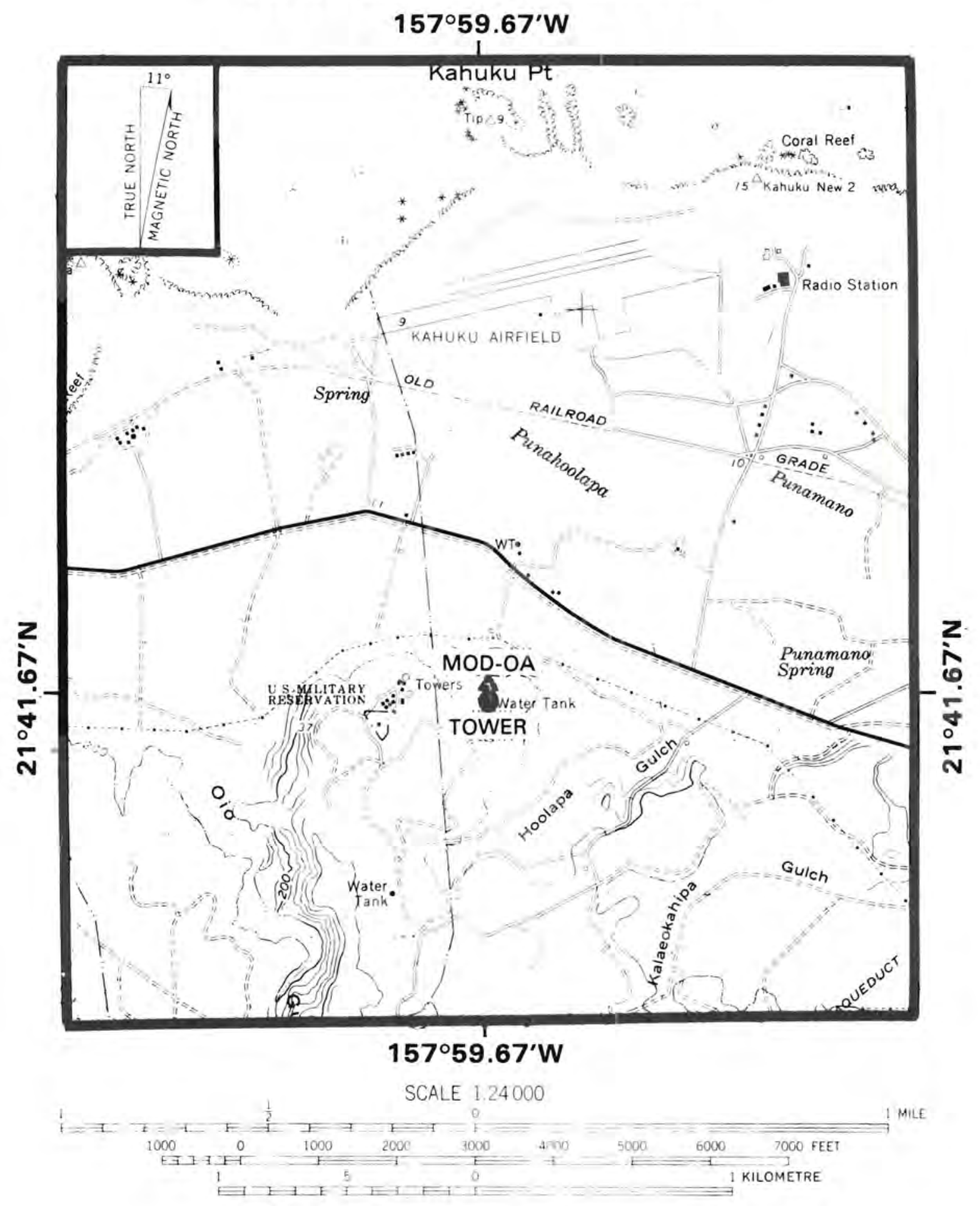




\section{KAHUA RANCH, HAWAII}

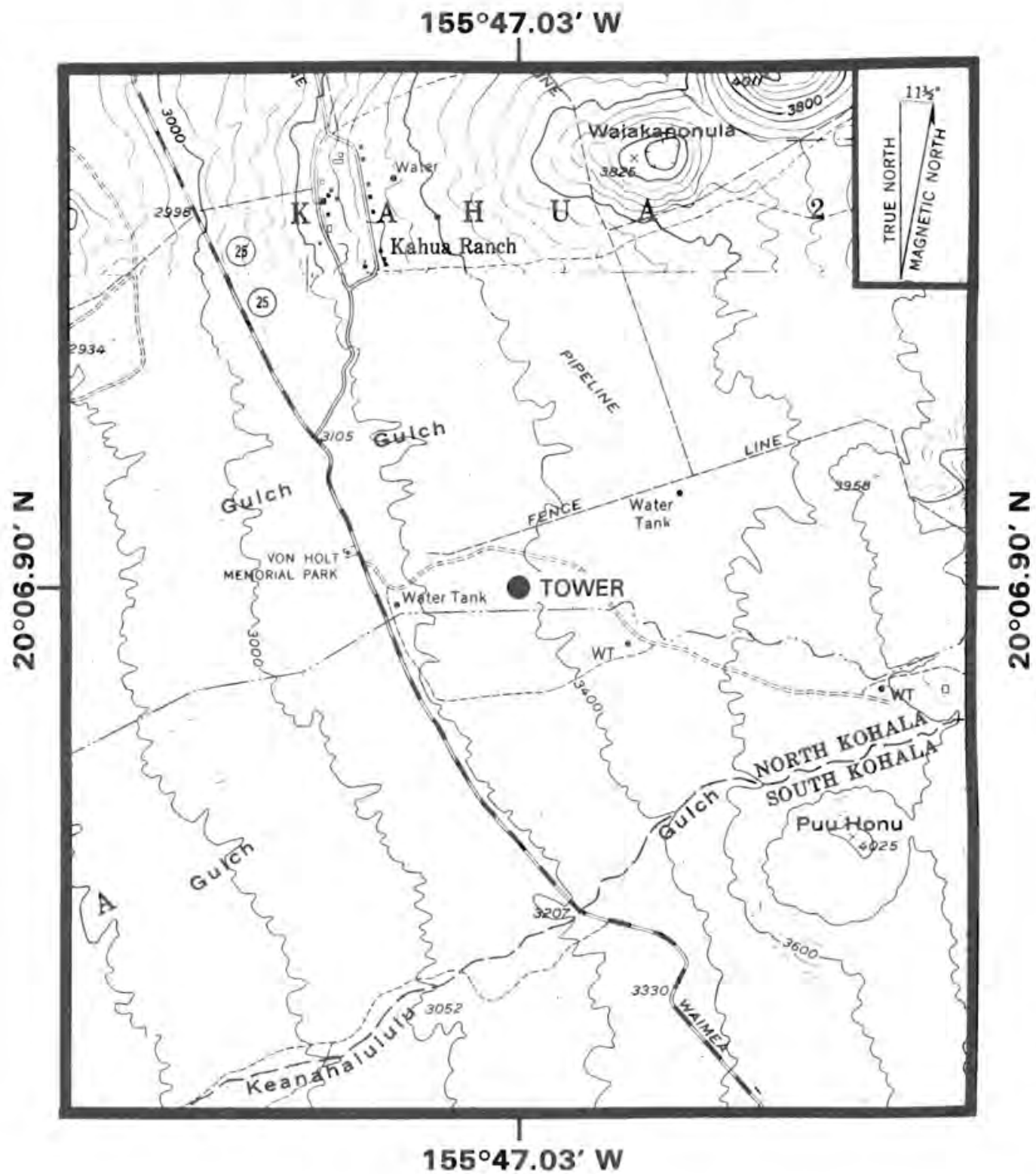

SCALE 1:24000

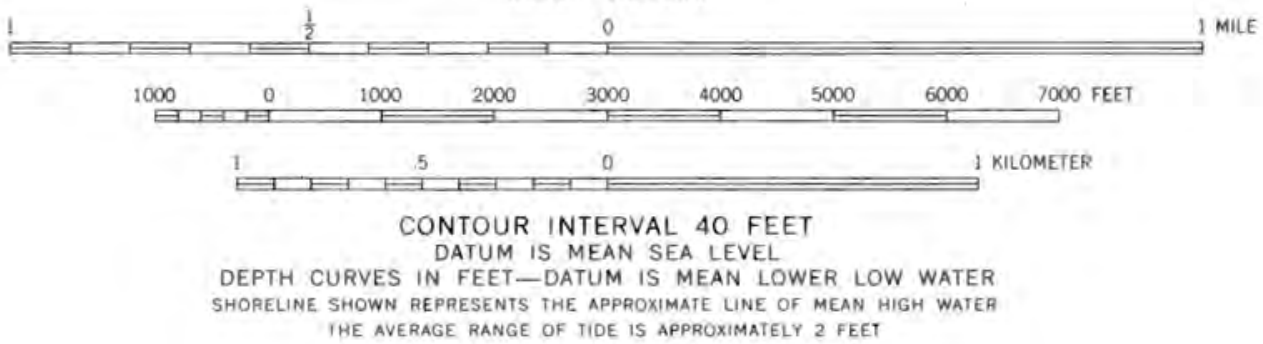




\section{KINGSLEY DAM, NEB. $101^{\circ} 39.75^{\prime} \mathrm{W}$}

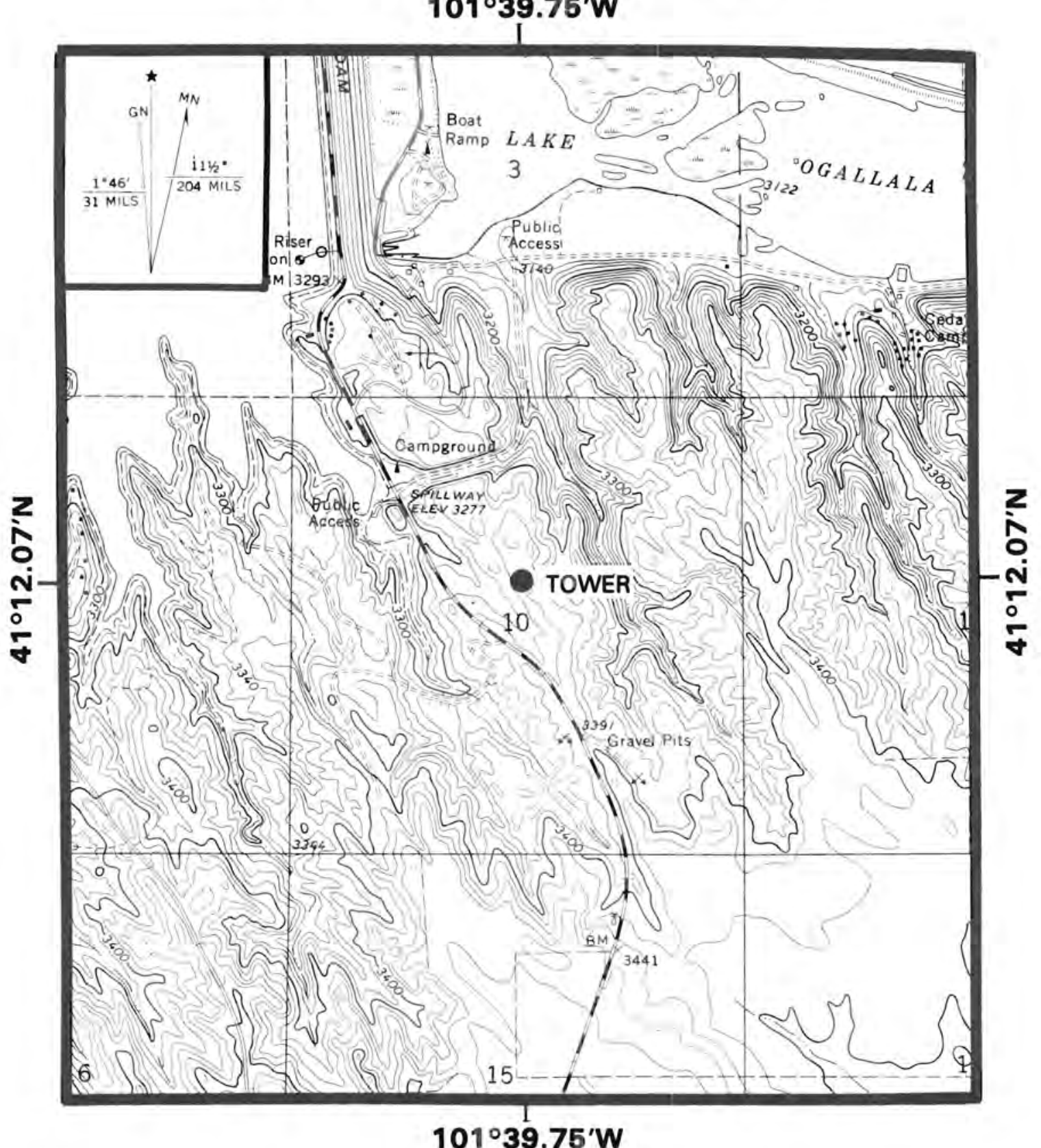

SCALE 1:24000

SCALE 1:24000
DOTTED LINES REPRESENT 5.FOOT CONTOURS
DATUM IS MEAN SEA LEVEL




\section{LIVINGSTON, MT}

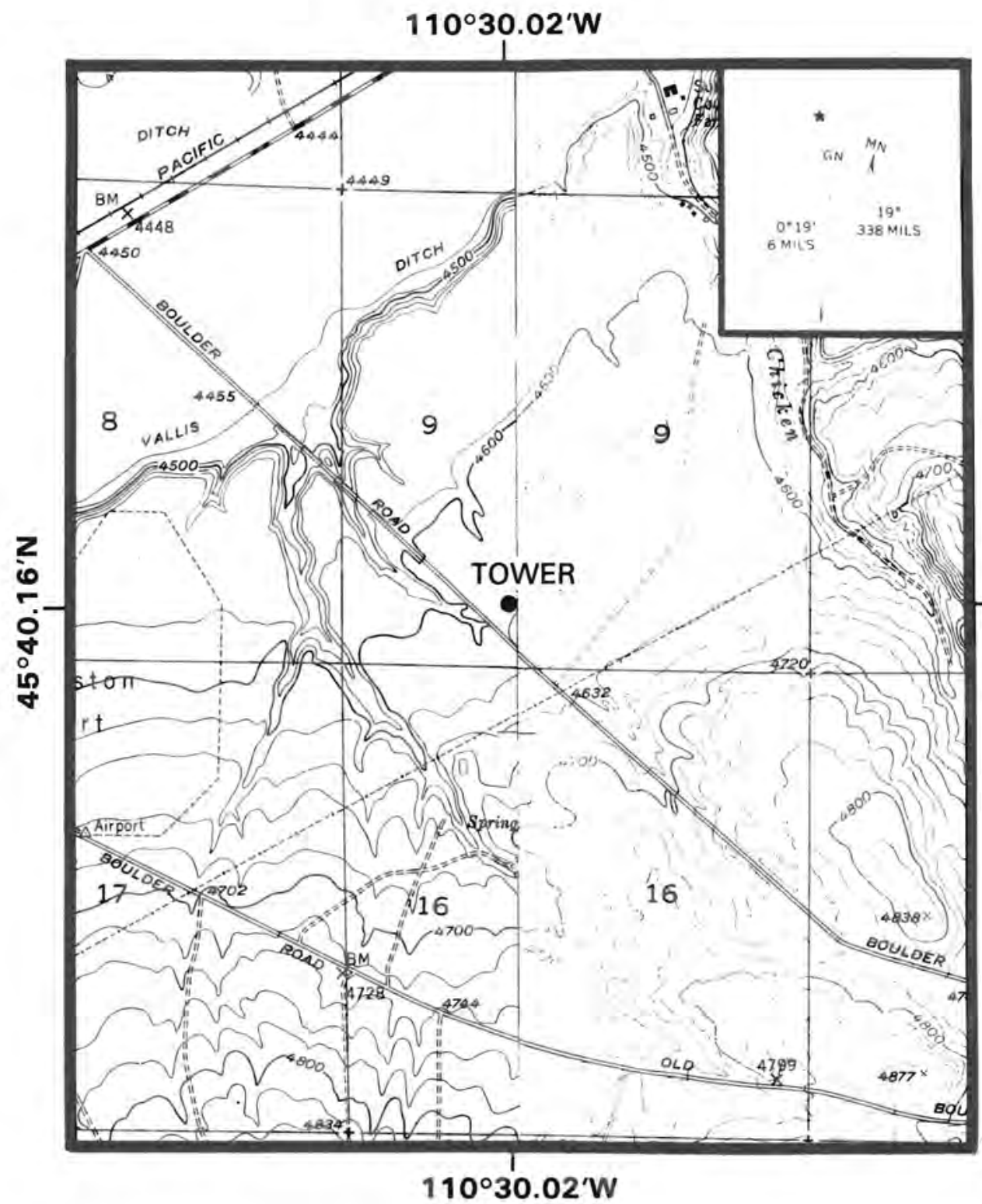

2
$i$
$\vdots$
0
0
in

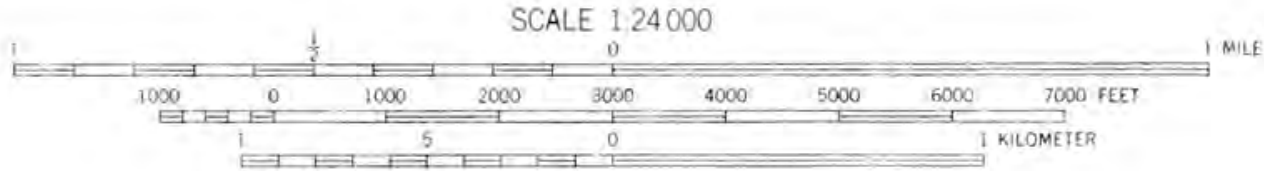

CONTOUR INTERVAL 20 FEET

NATIONAL GEODETIC VERTICAL DATUM OF 1929 


\section{LUDINGTON, MI}

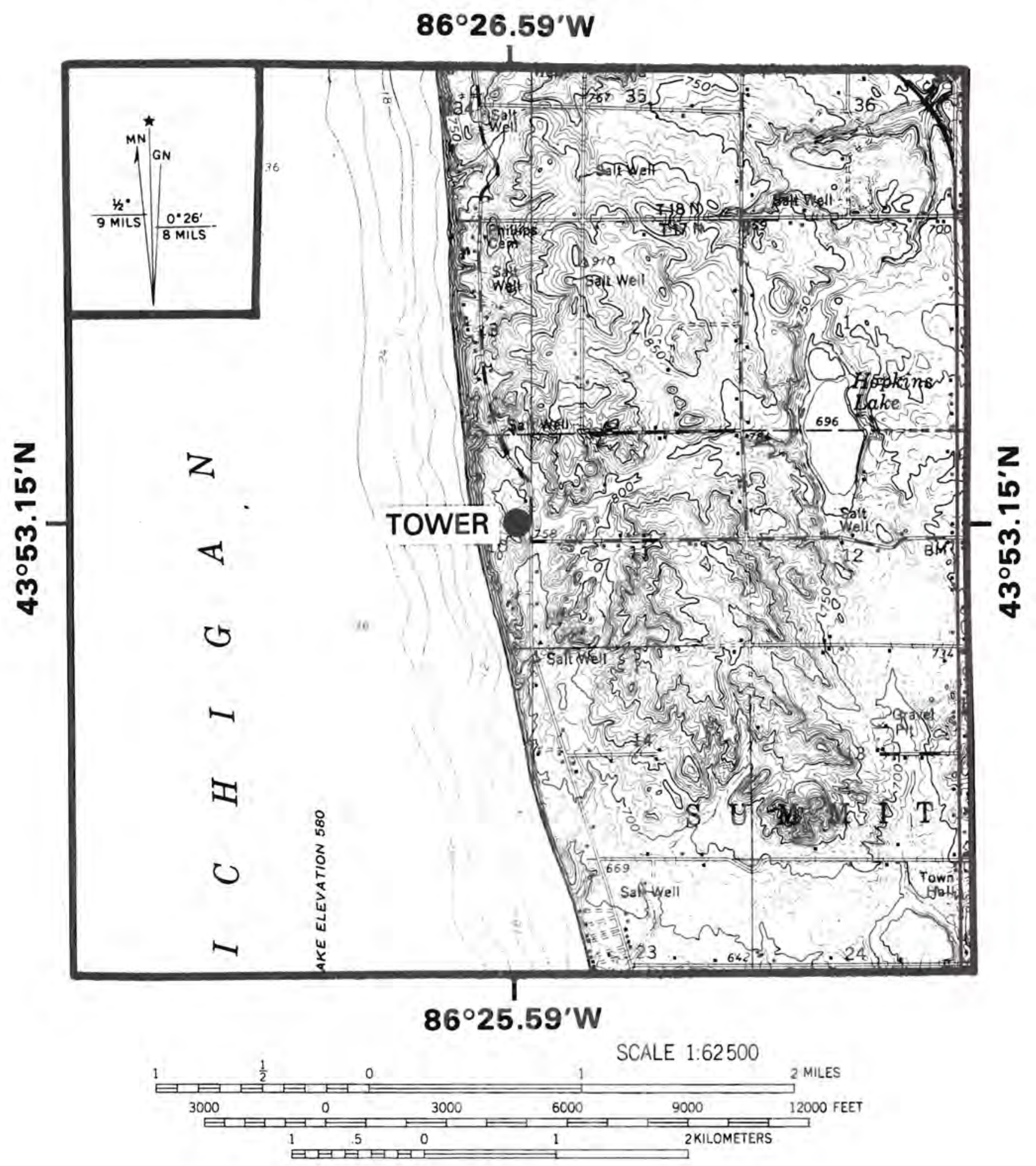




\section{MEADE, KS}
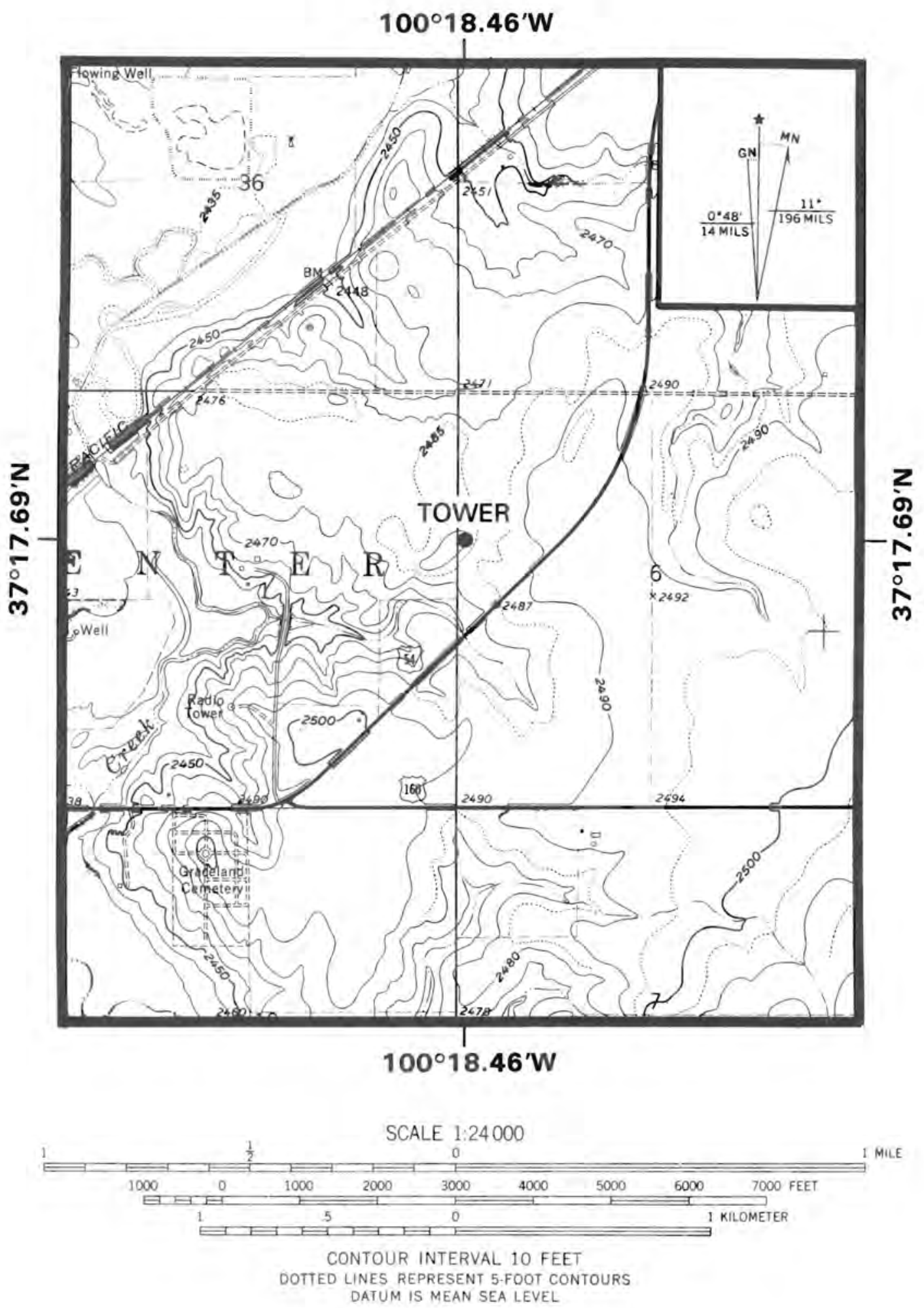


\section{MINOT, ND}
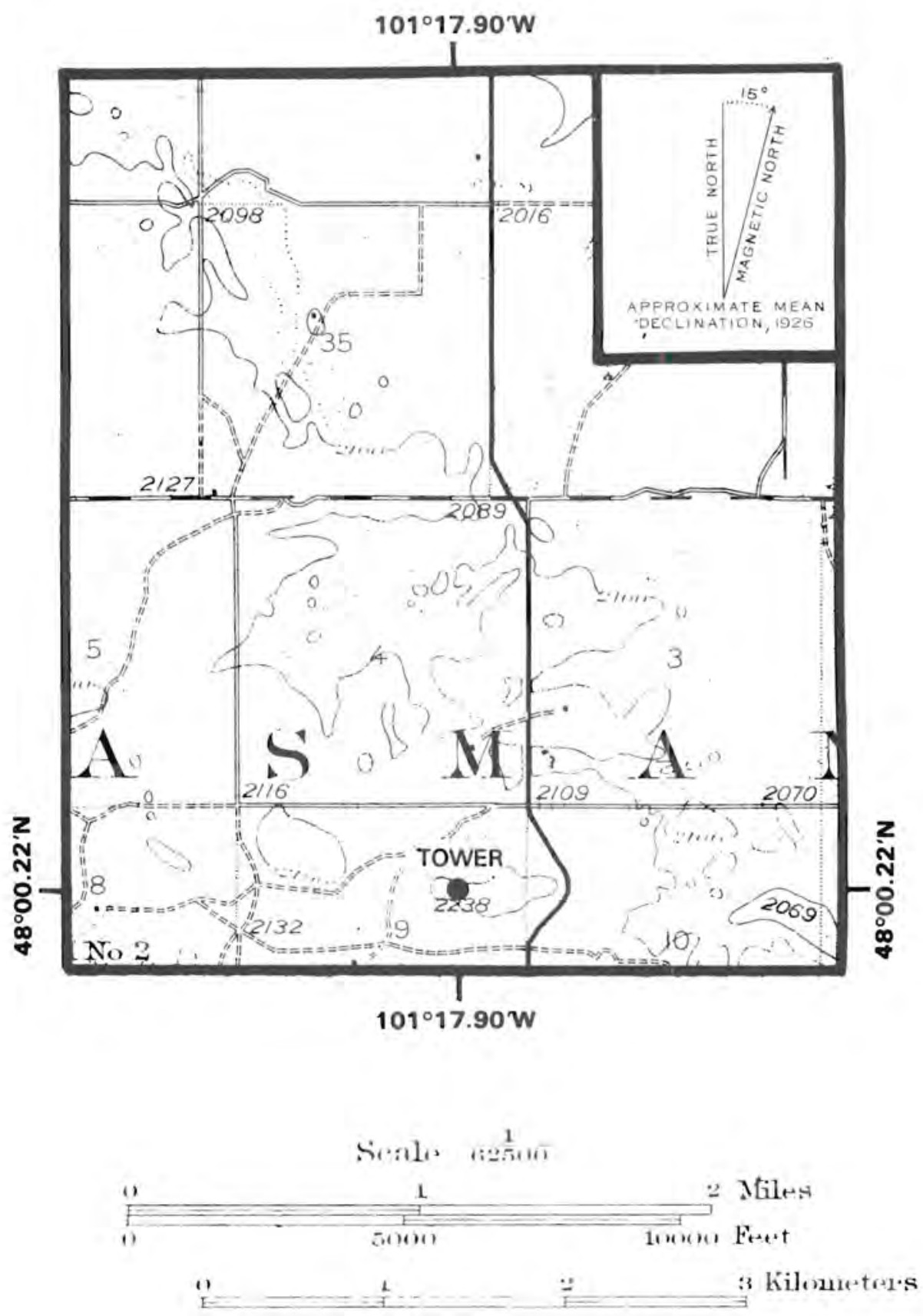

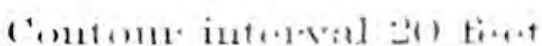

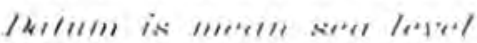




\section{MONTAUK, NY}

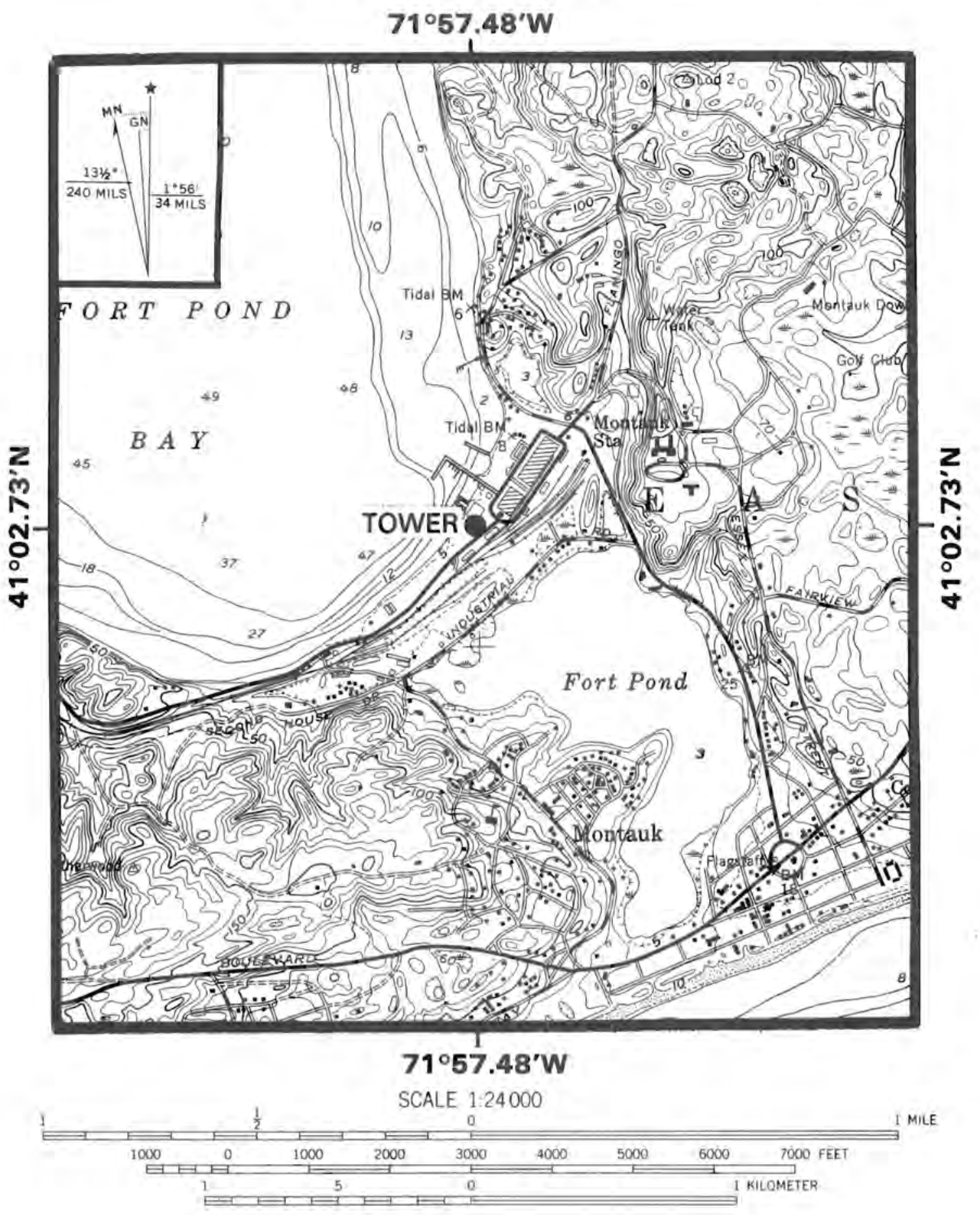




\section{NANTUCKET, MASSACHUSETTS}
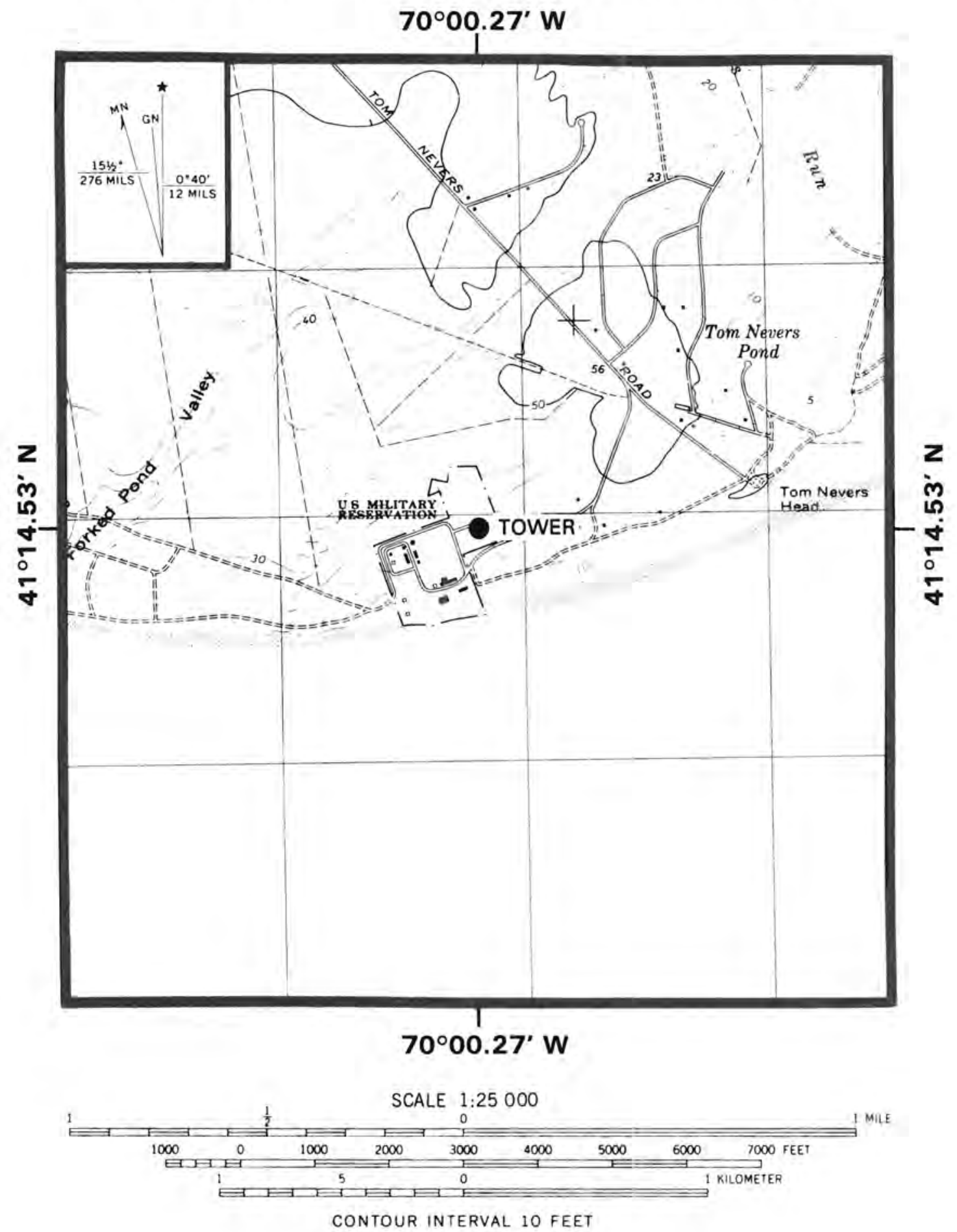


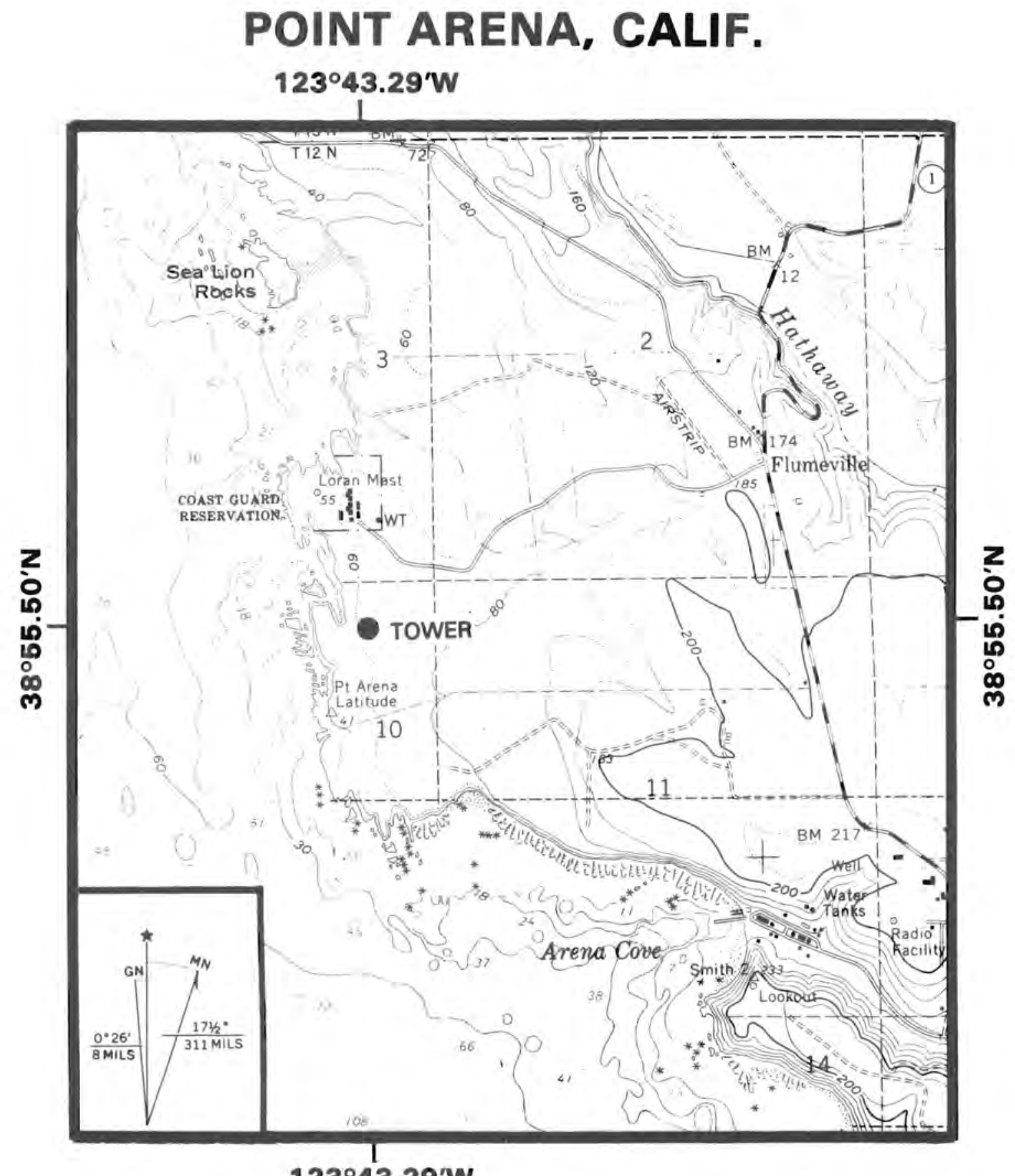

\section{$123^{\circ} 43.29^{\prime} \mathrm{W}$}

SCALE 1:24000

ב

CONTOUR INTERVAL 40 FEET

DOTTED LINES REPRESENT 20-FOOT CONTOURS

NATIONAL GEODETIC VERTICAL DATUM OF 1929

DEPTH CURVES AND SOUNDINGS IN FEET - DATUM IS MEAN LOWER LOW WATER

SHORELINE SHOWN REPRESENTS. THE APPROXIMATE LINE OF MEAN HIGH WATER

THE MEAN RANGE OF TIDE IS APPROXIMATELY 4 FEET 


\section{PROVINCETOWN, MASS.}

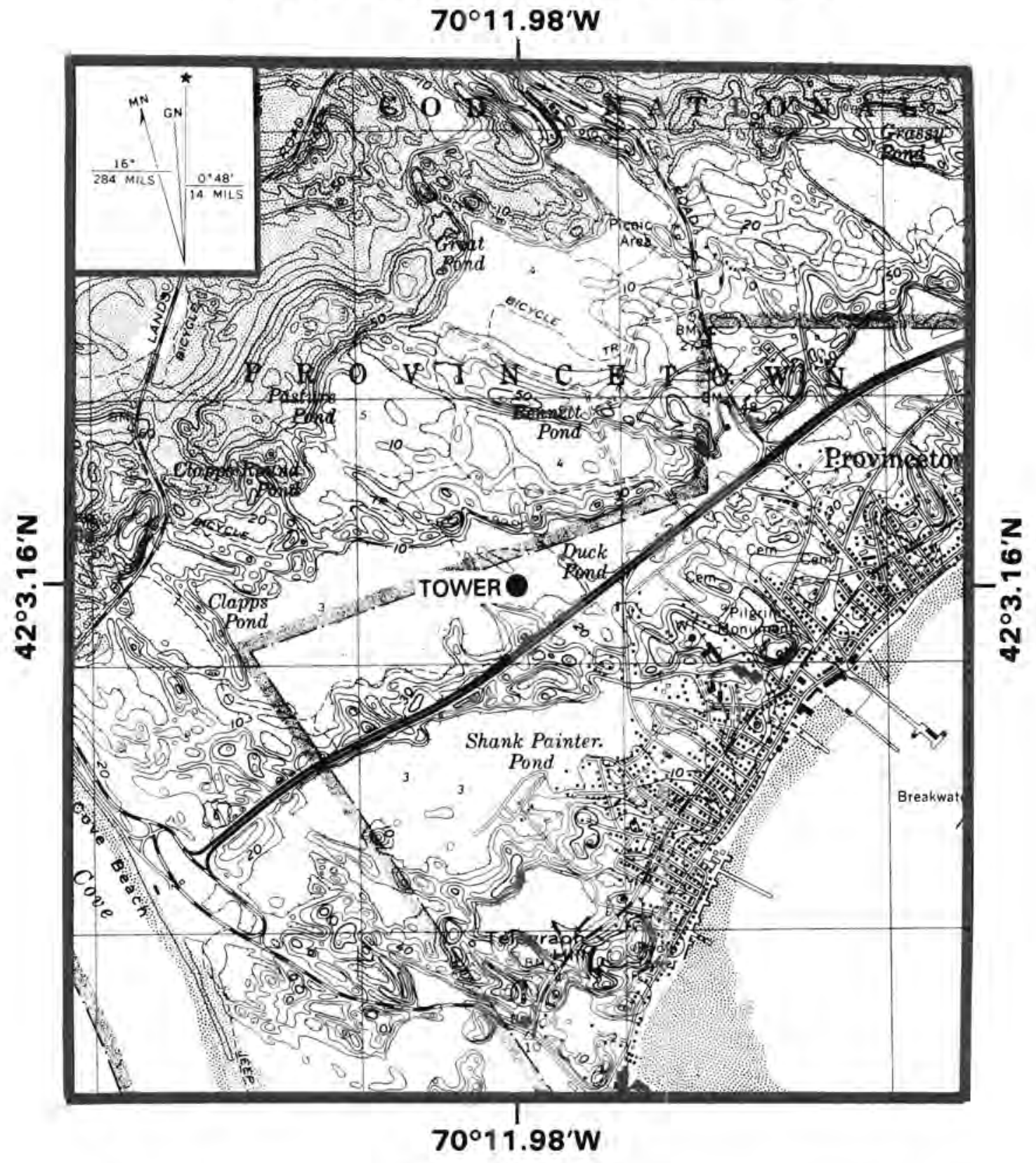

SCALE 1:25000

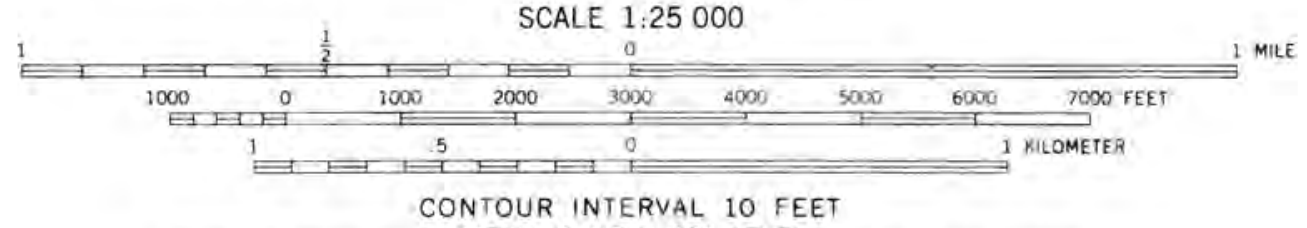

DATUM IS MEAN SEA LEVEL

DEPTH CURVES AND SOUNDINGS IN FEET - DATUM IS. MEAN LOW WATER

SHOBELINE SHOWN REPRESENTS THE APPROXIMATE LINE OF MEAN HLGH WUTER

THE MEAN RANGE of TIDE IS APPBONIMATEL 9 FEE 


\section{ROMERO OVERLOOK/ PACHECO PASS AREA, CA.}

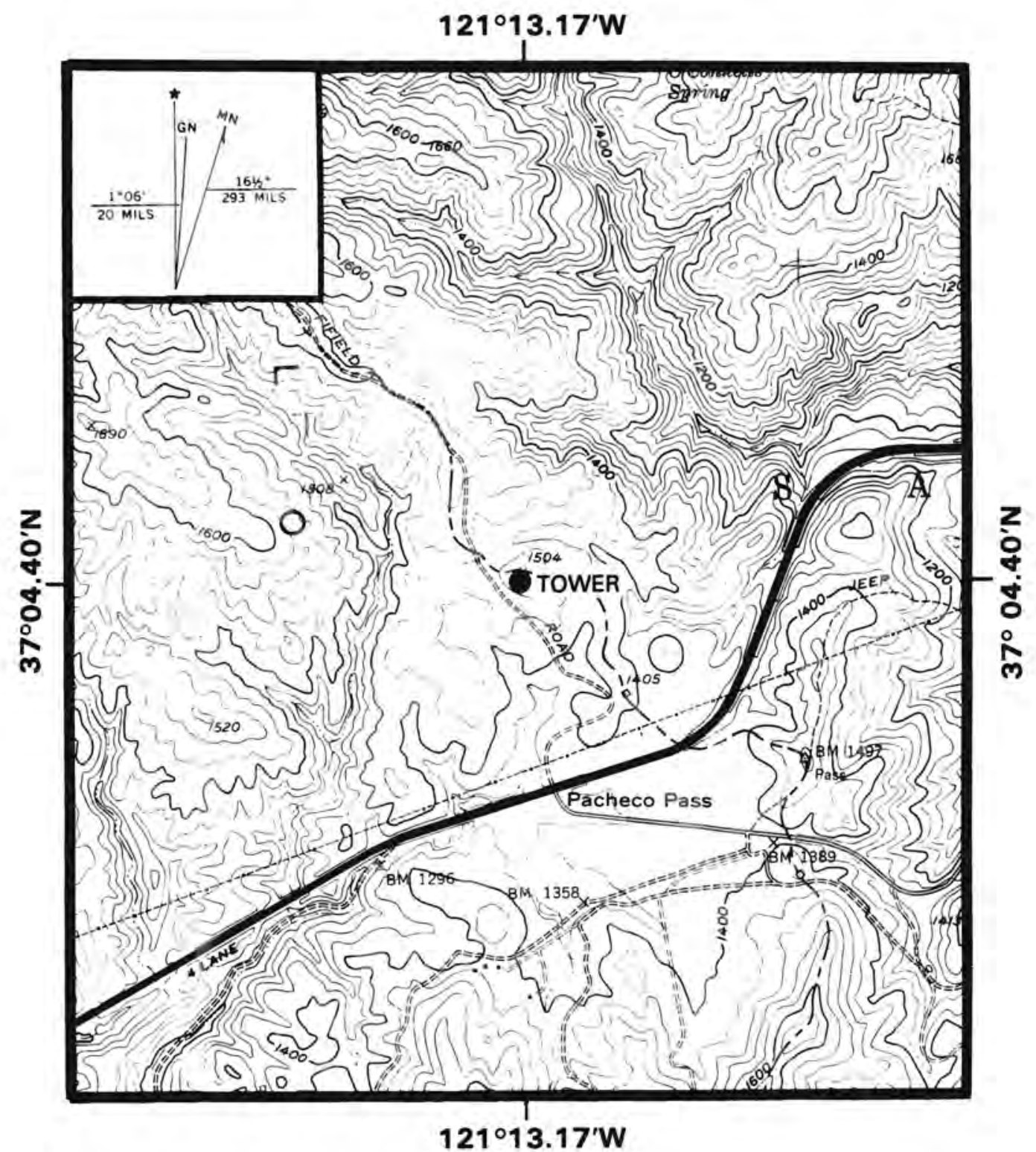

SCALE 1:24000

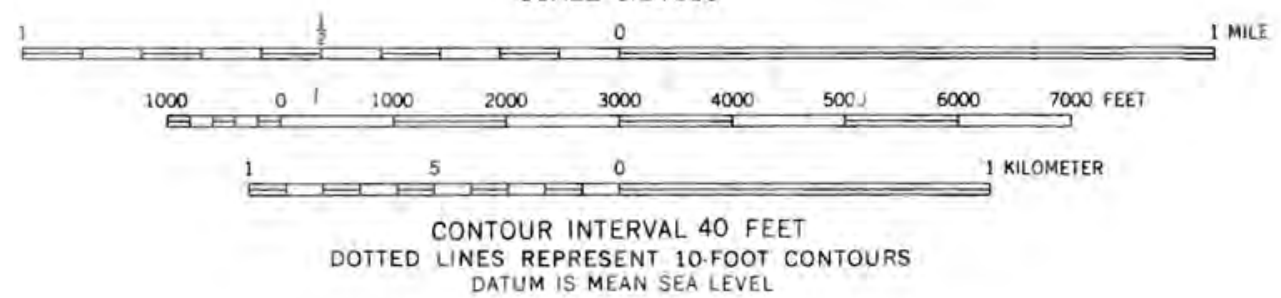


RUSSELL, KANSAS

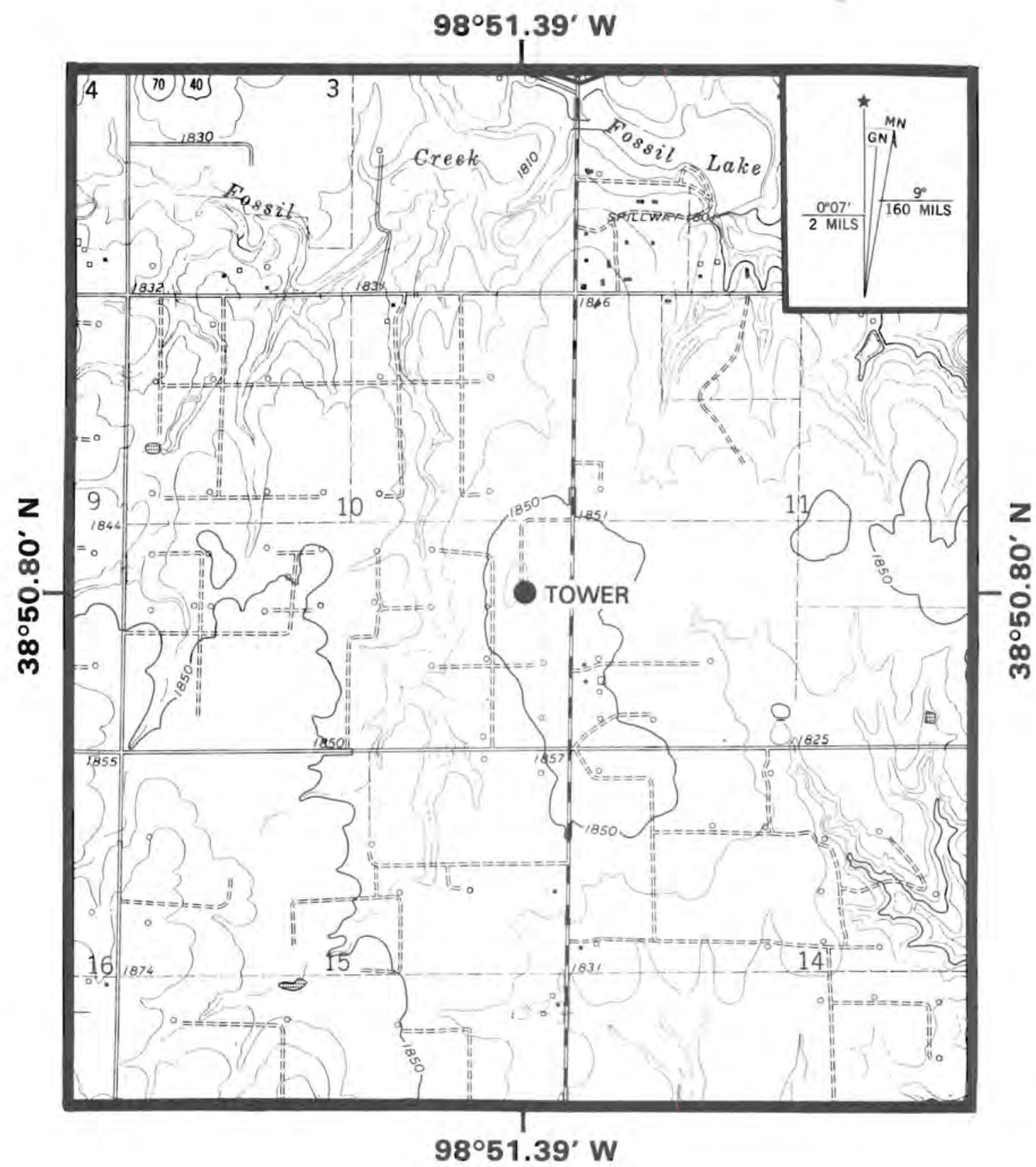

SCALE 1:24000

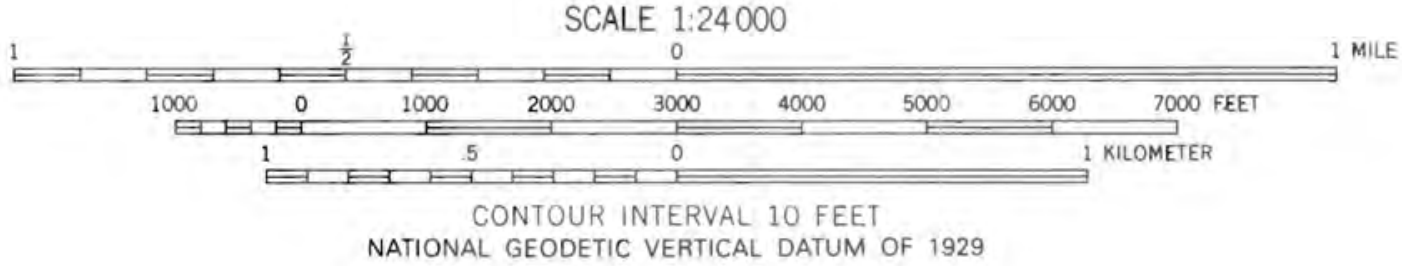




\section{SAN AUGUSTIN PASS, N. MEX. $106^{\circ} 33.93^{\prime} \mathrm{W}$}
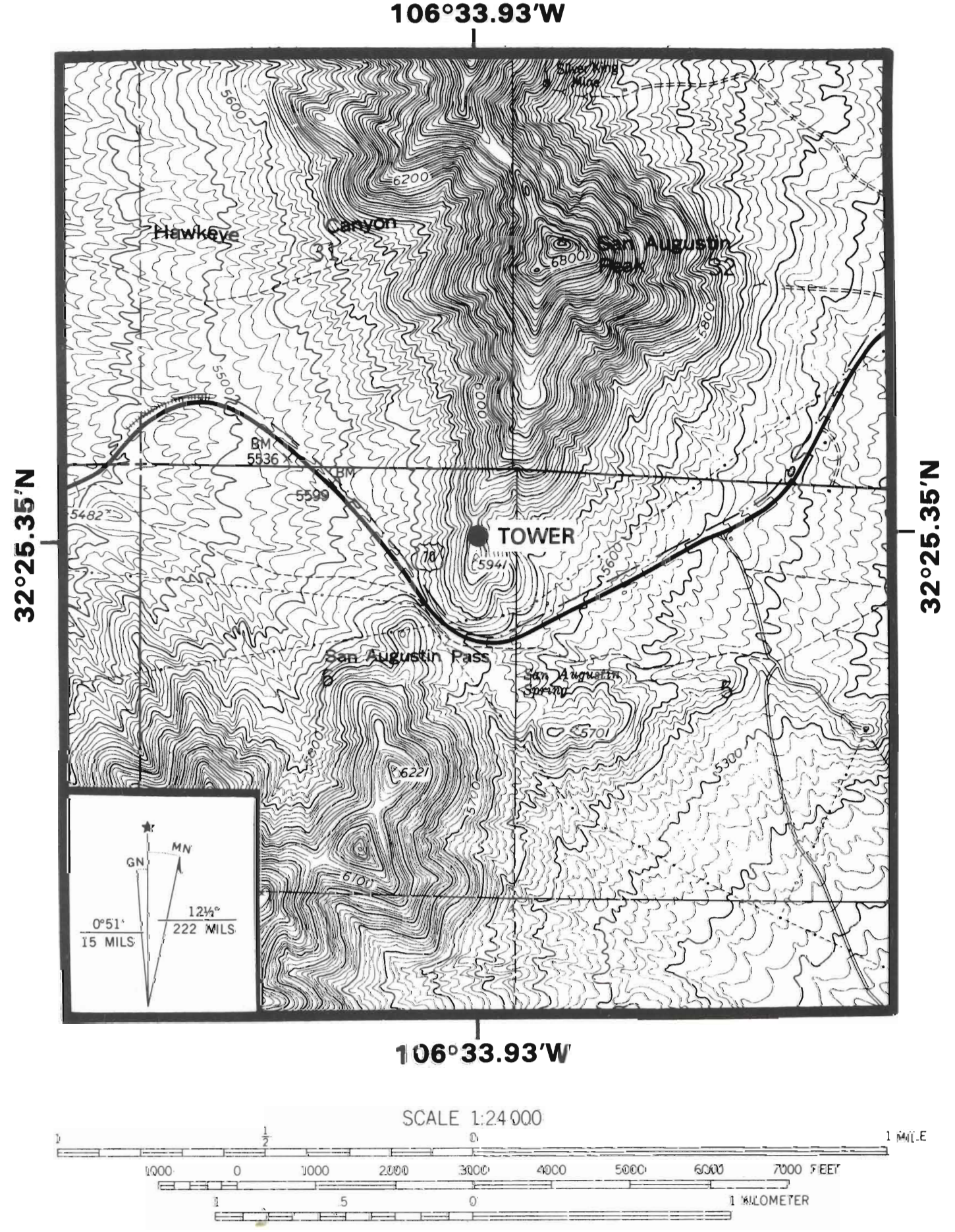

CONTOUR INTERVAL 20 FEET

NATIONAL GEODETIC VERTICAL DATUM OF 1929 


\section{SAN GORGONIO PASS, CA}

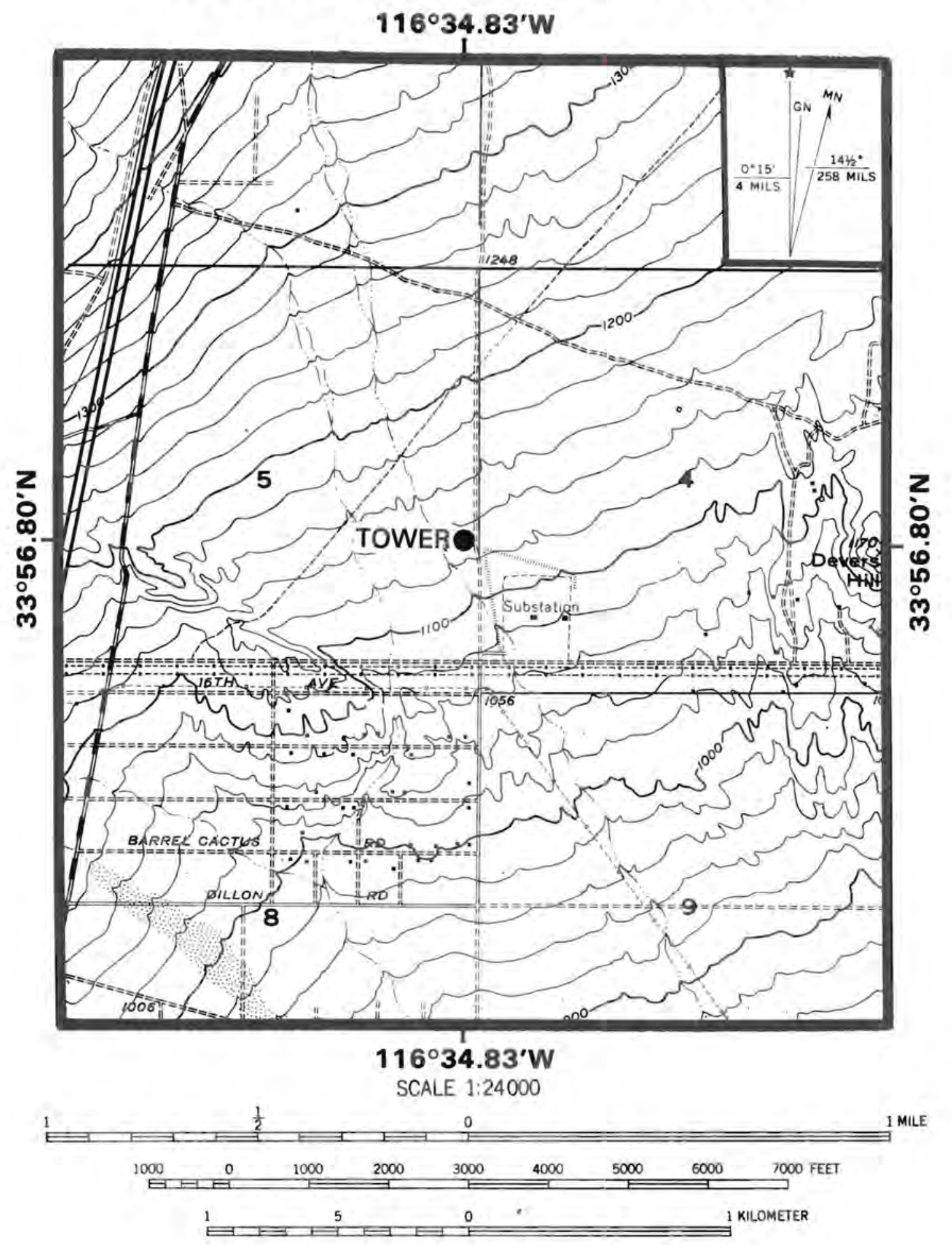




\section{STRATTON MOUNTAIN, VT}
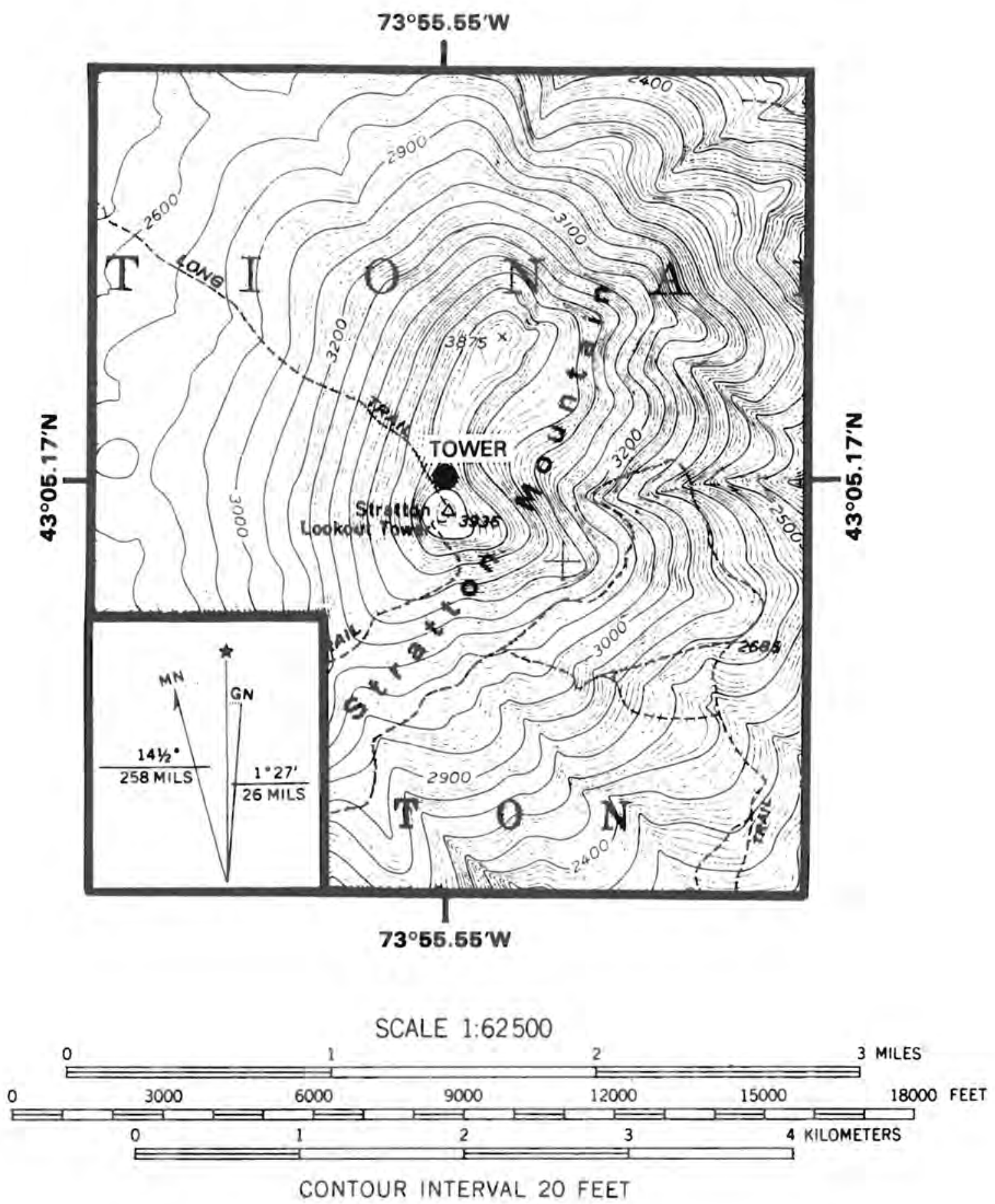


\section{TUCUMCARI, NM}
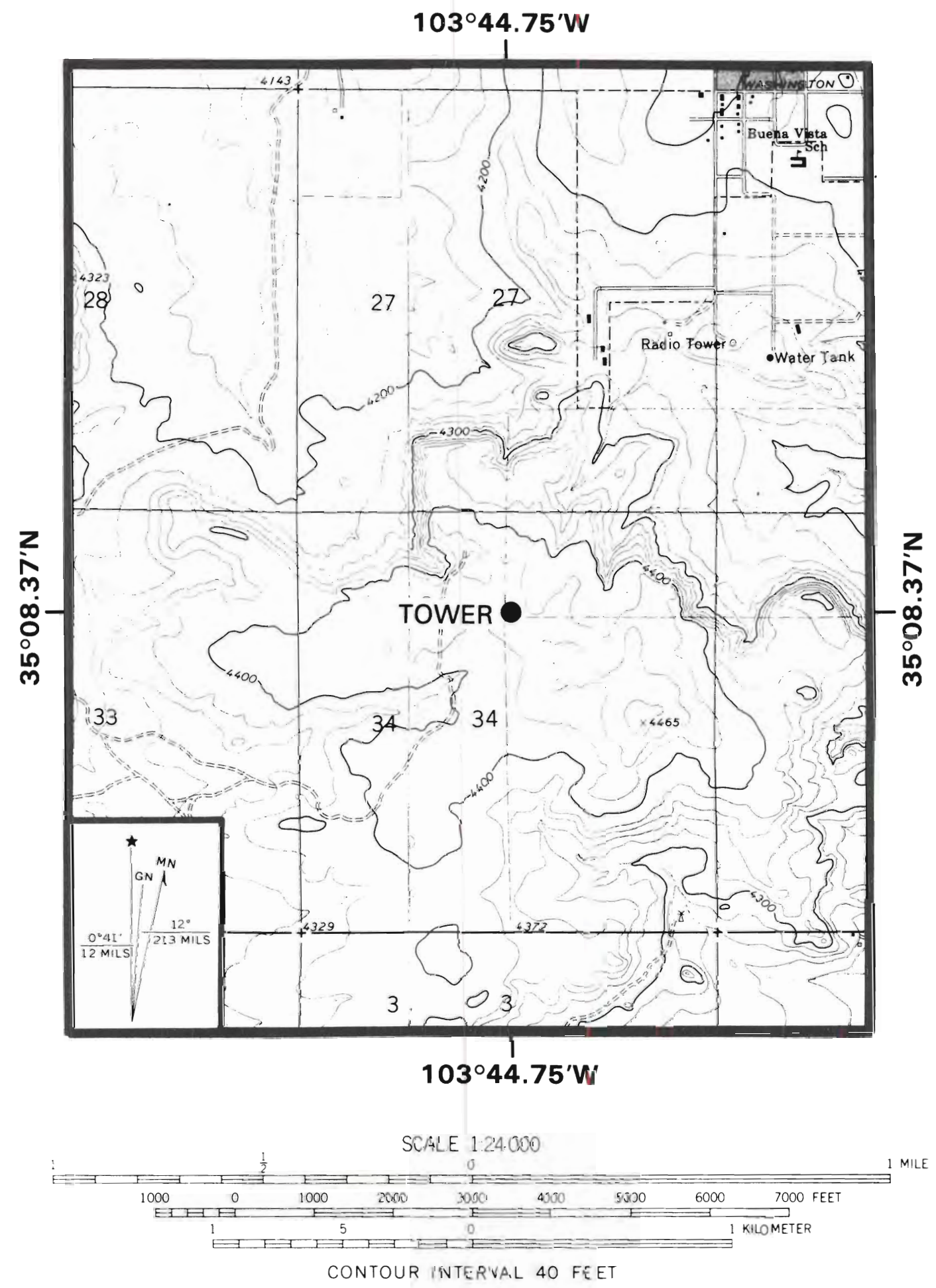


\section{WELLS, NEVADA}
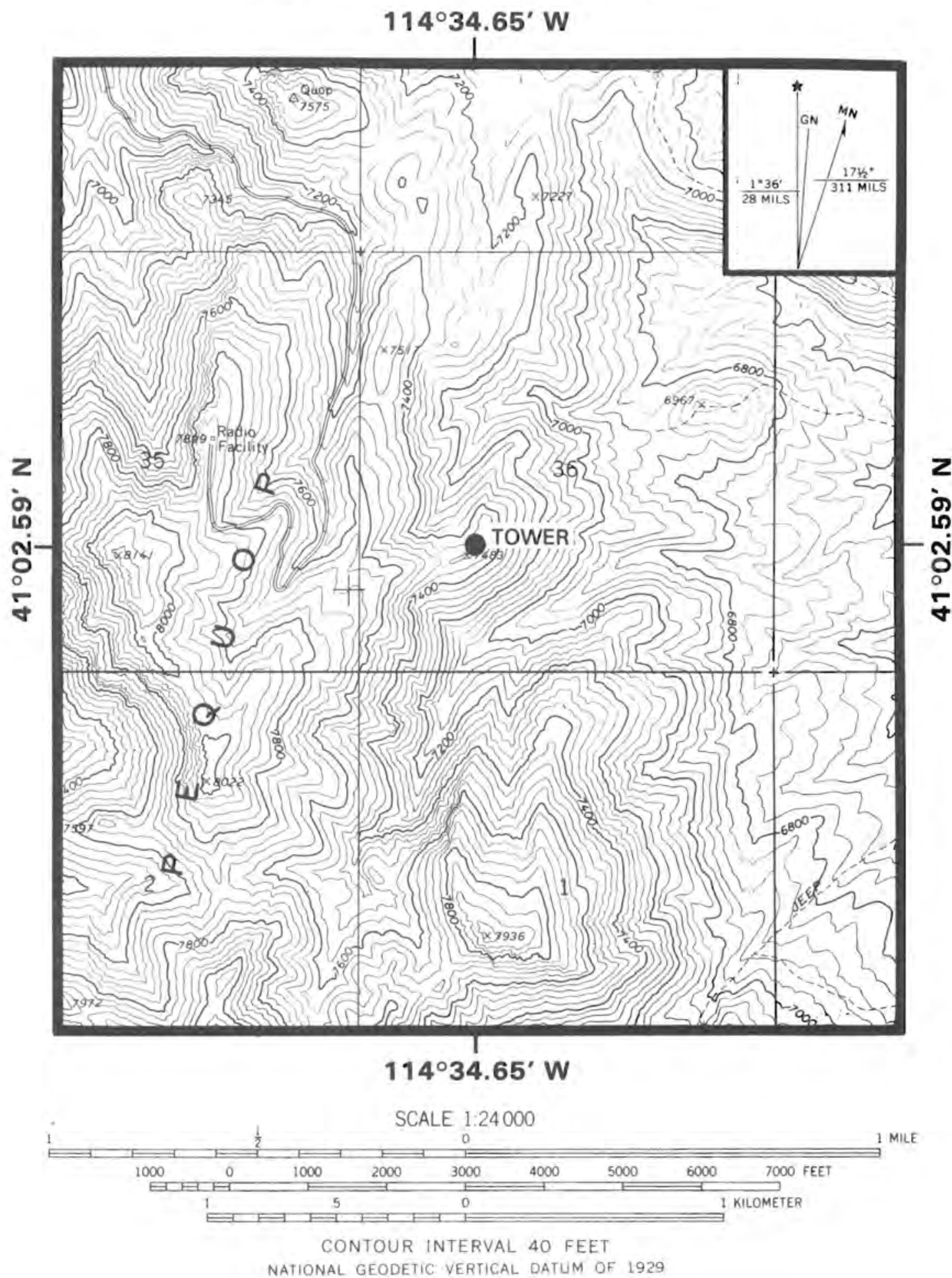


\section{DISTRIBUTION}

No. of

Copies

OFFSITE

Carl I. Aspliden

Battelle Memorial Institute Washington Operations Office 2030 M Street, N. W. Washington, DC 20036

George P. Tennyson

Department of Energy

A1buquerque Operations Office 4501 Indian School Road N.E.

Albuquerque, NM 87110

Sydney D. Berwager Wind Energy Technology Division 1000 Independence Avenue Forrestal Building, Room 5F059 Washington, DC 20585

\section{DOE Technical Information Center}

John Slagle

Alaska Bussell Electric Company P.0. Box 4-1325

Anchorage, AK 99509

Tom Gray

American Wind Energy Association 1621 Connecticut Avenue, N.W. Washington, DC 20009

Richard Katzenberg American Wind Energy Association Natura 7 Power, Inc. New Boston, NH 03070

Peter Smeallie AWEA Windletter 1609 Connecticut Avenue N.W. Washington, DC 20008
No. of

Copies
Larry Campbe11

Bechtel Power Corporation

P.0. Box 60860

Termina1 Annex

Los Angeles, CA 90060

Dale R. Bervig

10235 Oakmont Circle

Lenexa, KS 66215

Merritl E. Slate

Block Island Power Company

P.0. Box 518

Block Island, RI 02807

Grant Ayers

Blue Ridge Electric Corporation

1216 Blowing Rock Blvd., N.E.

Lenoir, NC 28645

John Lowe

Boeing Engineering and Construction

P.0. Box 3707

Mai1 Stop 9A-65

Seattle, WA 98124

Don McGrew

Boeing Engineering and Construction

P.0. Box 3707, Mai1 Stop 9A-67

Seattle, WA 98124

Douglas B. Seely/Ronald H. Holeman Bonneville Power Administration P.0. Box 3621

Portland, OR 97208

Nick Butler

Bonneville Power Administration

P.0. Box 3621

Portland, OR 97208 
G. Haldane Bradshaw, Manager Bridger Valley Electric Association Mountain View, WY 82939

Joe Hennessy

Wind Energy Program

California Energy Commission

1111 Howe Avenue, Mai1 Stop 66

Sacramento, CA 95825

Ed Hamilton

Central Nebraska Public Power and Irrigation District Inc.

P.0. Box 356

Holdrege, NB 68949

Michael Elliott

$\mathrm{CH} 2 \mathrm{M}-\mathrm{Hi} 11$

700 Clearwater Lane

P.0. Box 8748

Boise, ID 83706

Eli Garcia

City Manager

Clayton, NM 88415

Bob Tagelaar

Director of Research and Development

Commonwealth Energy Services, Inc. 627 Massachusetts Avenue

Cambridge, MA 02139

2 Ed Browning/Ron Calcaterra

Consumers Power Company

1945 W. Parnall Road

Jackson, MI 49201

Bob Drake

Port Orford District Manager

Coos-Curry Electric Cooperative

P.0. Box 460

Coquille, OR 97423
Congressman James K. Coyne

119 Cannon Building

Washington, DC 20515

Jeffrey Nelson

East River Electric Power

Co-op, Inc.

Madison, SD 57042

Paul Zieske

ECM Inc.

2145 Wells Street

Wailuku, Maui, HI 96793

Edgar DeMeo

Electric Power Research Institute 3412 Hillview Avenue

Palo Alto, CA 94303

James E. Brown, Director

Resource and Analysis

El Paso Electric Company

P.0. Box 982

215 N. Stanton Street

El Paso, TX 79960

Tom Carlson

Environmental Systems Corporation

200 Tech Center Drive

Knoxville, TN 37912

E. J. Babineaux

Facilities Engineering

Building 1950, ATZR-FEEO

Fort Sill, OK 73503

Tom Hiester

Flow Industries, Inc.

21414-68th Avenue South

Kent, WA 98031

Daniel DiGiovacchino

Advanced Energy Programs Department

General Electric Company

501 Allendale Road, P.0. Box 527

King of Prussia, PA 19406 
No. of

Copies

2 Art Jackson/Thad M. Hasbrouck Hamilton Standard Division United Technologies Corporation Windsor Lock, CN 06096

E. Chipman Higgins

Director, Energy Supply

Hawaiian Electric Company

Box 2750

Honolu7u, HI 96840

Tom Jezierny

Hawaiian Electric Company

Box 2750

Honolulu, HI 96840

Fred Johnson

President, Energy Supply

Hawaii Electric Light Company, Inc.

P.0. Box 1027

Hi10, HI 96720

D. Richard $\mathrm{Ne} i 11$

Hawaii Natural Energy Institute

University of Hawaii at Manoa

2540 Dole Street

Honolu7u, HI 96822

Anders Daniels

Associate Professor

Department of Meteorology

University of Hawai i at Manoa

HonoluTu, HI 96822

George Leary

City of Holyoke

Gas and Electric Department

70 Suffolk Street

Holyoke, MA 01040

Anton Tonc/Craig Meecham

Intermountain Consumer Power Association

8722 South 300 West

P.0. Box BB

Sandy, UT 84070
No, of

Copies

Monte M. Richards

Kahua Ranch, Box 837

Kamuela, HI 96743

Andrew Matura

Senior Research and Development Engineer

Long Island Lighting Company

175 East 01d Country Road

Hicksville, NY 11801

Frank Porretto

Long Island Lighting Company

175 East 01d Country Road

Hicksville, NY 11801

Douglas W. Fisher

City Superintendent

132 South Fowler

Meade, KS 67864

John H. Urauchi

Superintendent of Administration

Molokai Electric Company, Ltd.

P.0. Box 378

Kaunakakai, HI 96748

Paut Laird

The Montana Energy and MHD Research and Development Institute

P.0. Box 3809

Butte, MT 59701

Leonard Decco

Montana Power Company

$40 \mathrm{E}$. Broadway

Butte, MT 59701

2 K. Dun Gifford/Linda Holland Nantucket Electric Company Fairgrounds Road, P.0. Box 179 Nantucket, MA 02554 
No. of

Copies

Robert Wasel

Energy Systems Division

National Aeronautics and Space

Administration

600 Independence Avenue, S.W.

Washington, DC 20546

10 Ronald Thomas

NASA/Lewis Research Center

21000 Brookpark Road

Cleveland, $\mathrm{OH} \quad 44135$

3 Phillip French

NASA Scientific and Technical Information Facility

P.0. Box 8757

Ba1timore/Washington International Airport

Baltimore, MD 21240

M. J. Changery

National Oceanic and Atmospheric Administration

National Climatic Center

Federal Building

Asheville, NC 28801

R. Thomas Segall

Geologist-in-Charge

Geological Survey Division

Department of Natural Resources

Box 30028

Lansing, MI 48909

2 Rudi Schoenmackers/Ken Barnett

Wind Energy Division

New Mexico Solar Energy Institute

P.0. Box 3SOL

Las Cruces, NM 88003

Eugene N, Frey

New Mexico Engineering Research Institute

The University of New Mexico

A1buquerque, NM 87131
No. of

Copies

John C. Baiardi, Director

New York Ocean Science Laboratory

Montauk, NY 11954

Don Bain

Department of Energy

State of Oregon

Labor and Industries Building

Room 111

Salem, OR 98310

J. E. Wade

Department of Atmospheric Sciences

Oregon State University

Corvallis, OR 97331

Tom Hillesland

Pacific Gas and Electric Company

Department of Engineering Research

3400 Crow Canyon Road

San Ramon, CA 94583

John H. Matteson

Pioneer Valley Air Pollution

Control District

1414 State Street

Springfield, MA 01709

3 Ernel L. Luther

Planning Research Corporation

1500 Planning Research Drive

McLean, VA 22102

Norman Sanesi

Portland General Electric Company

121 S.W. Salmon Street

Portland, OR 97204

Orlando Anglero

Puerto Rico Electric Power Authority

G.P.0. Box 4267

San Juan, PR 00936 
No. of

Copies

Gary Braty

Public Service Company of Oklahoma

Division of Conservation Services

P.0. Box 828

Lawton, OK 73502

Terry J. Healy

Rockwell International

Rocky Flats Plant

P.0. Box 464

Golden, C0 80401

Ear1 Homewood

City of Russe11

P.0. Box 112

Russe11, KS 67665

Alan T. Yamagiwa, P. E.

Senior Mechanical Engineer

Seattle City Light Department

1015 Third Avenue

Seattle, WA 98104

Merle Holden

Project Manager

Sheyenne Valley Electric Co-op

Finley, ND 58230

2 Roger Taylor/Neil D. Kelley

Solar Energy Research Institute

1617 Cole Boulevard

Golden, C0 80401

2 Robert Noun/Rick Mitchel1

Solar Energy Research Institute

1617 Cole Boulevard

Golden, CO 80401

Robert Scheffler

Southern California Edison

P.0. Box 800

Rosemead, CA 91770
No. of

Copies

2 Kenneth Ladd/Tim Titus

Southwest Public Service Company

P.0. Box 1261

Amari110, TX 79170

Hugh RiTey, Director

Community Planning and Development

City of Tucumcari

Municipal Power Company

P.0. Box 1188

Tucumicari, NM 88401

Wa11y Beyer

Genera 1 Manager

Verendrye Electric Cooperative, Inc.

Velva, ND 58790

Lars Nygren

Verendrye Electric Cooperative, Inc.

Rural Route 5, Box 4

Minot, ND 58701

01 in J. Bohn

Chief Engineer

Vermont Electric Cooperative

School Street

Johnson, VT 05656

John DeGlow

Department of Water Resources

P.0. Box 388

Sacramento, CA 95802

Lee Standley

General Manager

Wells Rural Electric Company

P.0. Box 365

WelTs, NV 89835

W. R. Thorn, Manager

Wind Systems Engineering

TERA Corporation

2150 Shattuck Avenue

Berkeley, CA 94704 
No. of

Copies

John Goll

U.S. Minerals Management Service 12203 Sunrise Valley Drive

Mail Stop 640

Reston, VA 22092

Earl L. Davis

U.S. Windpower, Inc.

6421 B. South Front Road

Livermore, CA 94550

Ron Nierenberg

Windfarms, Ltd.

639 Front Street

San Francisco, CA 94111

Alfred J. Gross, Vice President WTG Energy Systems, Inc.

251 Elm Street

Buffalo, NY 14203

Dr. Neil Cherry

Lincoln College

Canterbury

NEW ZEALAND
No. of

Copies

ONSITE

DOE Richland Operations Office

H. E. Ransom/D. R. Segna

46 Pacific Northwest Laboratory

W. R. Barchet

J. W. Buck

J. R. Connel1

C. E. Elderkin

D. L. Elliott

D. L. Hadley

A. H. Miller

E. L. Owczarski

J. V. Ramsdell

D. S. Renné

W. F. Sandusky

H. L. Wegley

L. L. Wende11

R. K. Woodruff

Technical Information - Library (5)

Publishing Coordination (2)

WCPE Program Office (15)

2400 Stevens Library (10) 